\title{
UNDERGROUND PLACEMENT OF COAL PROCESSING WASTE AND COAL COMBUSTION BY-PRODUCTS BASED PASTE BACKFILL FOR ENHANCED MINING ECONOMICS
}

FINAL REPORT

by

Y. P. Chugh, D. Biswas and D. Deb

Department of Mining and Mineral Resources Engineering

Southern Illinois University-Carbondale (SIUC)

Carbondale, Illinois 62901-6603

Prepared for

United States Department of Energy

National Energy Technology Laboratory

626 Cochrans Mill Road, P. O. Box 10940

Pittsburgh, Pennsylvania 15236-0940

Project Manager: Dr Peter Botros

Project Contract No.: DE-FC26-99FT40553

June. 2002 


\section{ACKNOWLEDGEMENTS}

On behalf of the project team, the principal investigator expresses his sincere gratitude to the following individuals and organizations.

- U.S. Department of Energy and National Energy Technology Laboratory for their financial and technical support. Particular thanks are due to Dr. Peter Botros and Mr. Scott Renninger, Project managers for the project.

- Illinois Clean Coal Institute, Office of Coal Development DCCA for financial support, and technical direction.

- Freeman United Coal Company and Crown III Operations staff for their unequivocal support. Particular thanks are due to Mr. Mike Caldwell and Mr. Bill Giles.

- West Virginia University for providing the Groutnet program for grout flow simulation.

- Project steering committee members for their time, encouragement, and their direction.

- Office of Surface Mining for providing the borehole camera and staff for borehole surveys.

- Cement-Tech Corporation of Iowa for donating high-speed auger system for the study.

- Members of the project team who worked diligently to complete the project under very challenging circumstances.

\section{DISCLAIMER STATEMENT}

This report was prepared by Dr. Y. P. Chugh of Southern Illinois University at Carbondale with support, in part by grants made possible by the U.S. Department of Energy. Neither Dr. Y. P. Chugh of Southern Illinois University at Carbondale nor any of its subcontractors nor the U.S. Department of Energy, nor any person acting on behalf of either:

(A) Makes any warranty of representation, express or implied, with respect to the accuracy, completeness, or usefulness of the information contained in this report, or that the use of any information, apparatus, method, or process disclosed in this report may not infringe privately-owned rights; or

(B) Assumes any liabilities with respect to the use of, or for damages resulting from the use of, any information, apparatus, method or process disclosed in this report.

Reference herein to any specific commercial product, process, or service by trade name, trademark, manufacturer, or otherwise, does not necessarily constitute or imply its 
endorsement, recommendation, or favoring; nor do the views and opinions of authors expressed herein necessarily state or reflect those of the U.S. Department of Energy. 


\begin{abstract}
This project has successfully demonstrated that the extraction ratio in a room-and-pillar panel at an Illinois mine can be increased from the current value of approximately $56 \%$ to about $64 \%$, with backfilling done from the surface upon completion of all mining activities. This was achieved without significant ground control problems due to the increased extraction ratio. The mined-out areas were backfilled from the surface with gob, coal combustion by-products (CCBs), and fine coal processing waste (FCPW)based paste backfill containing $65 \%-70 \%$ solids to minimize short-term and long-term surface deformations risk. This concept has the potential to increase mine productivity, reduce mining costs, manage large volumes of CCBs beneficially, and improve the miner's health, safety, and environment.
\end{abstract}

Two injection holes were drilled over the demonstration panel to inject the paste backfill. Backfilling was started on August 11, 1999 through the first borehole. About 9,293 tons of paste backfill were injected through this borehole with a maximum flow distance of 300-ft underground. On September 27, 2000, backfilling operation was resumed through the second borehole with a mixture of $\mathrm{F}$ ash and $\mathrm{FBC}$ ash. A high-speed auger mixer (new technology) was used to mix solids with water. About 6,000 tons of paste backfill were injected underground through this hole. Underground backfilling using the "Groutnet" flow model was simulated. Studies indicate that grout flow over 300-foot distance is possible. Approximately 13,000 tons of grout may be pumped through a single hole.

The effect of backfilling on the stability of the mine workings was analyzed using SIUPANEL.3D computer program and further verified using finite element analysis techniques. Stiffness of the backfill mix is most critical for enhancing the stability of mine workings. Mine openings do not have to be completely backfilled to enhance their stability. Backfill height of about $50 \%$ of the seam height is adequate to minimize surface deformations.

Freeman United Coal Company performed engineering economic evaluation studies for commercialization. They found that the costs for underground management at the Crown III mine would be slightly higher than surface management at this time.

The developed technologies have commercial potential but each site must be analyzed on its merit. The Company maintains significant interest in commercializing the technology. 


\section{EXECUTIVE SUMMARY}

In order to maintain a healthy Illinois high-sulfur coal industry, production costs must be reduced and economically viable management technologies for coal combustion byproducts $(\mathrm{CCBs})$, fine coal processing waste (FCPW) and coarse coal processing waste (gob) must be developed. Over the past decade considerable research has been done in Illinois on high volume, low-value disposal/utilization technologies (disposal in surface mines, reclamation, disposal in abandoned underground mine workings). However, little or no work has been done to beneficially use these by-products in large volumes to enhance the economics of mining coal and power generation.

About $70 \%$ of the underground mined coal in Illinois is extracted using a room-and-pillar mining method that permits extraction of about $50 \%$ of the coal. The remaining coal is left behind in the form of support pillars to control surface and subsurface movements. Typically, power plants in Illinois, in rural settings, are presently spending about $\$ 10 /$ ton to dispose of CCBs on-site in ponds. Nationwide, this cost is about is about $\$ 20 /$ ton. This cost is expected to grow rapidly in light of new requirements for landfill sites. If coal companies could negotiate coal contracts with electric utility companies, which will reduce their CCBs management costs and cover the cost of underground backfilling and transportation, the hypothesis for partial extraction mining with backfilling is economically feasible. Implementation of this technology will result in strengthening the high sulfur Illinois coal industry and keeping the coal industry jobs in Illinois while providing a secure source of coal supply to power plants from their backyards.

Toward the above goal, this project has successfully demonstrated that: 1) the extraction ratio in a room-and-pillar geometry at the demonstration mine can be increased from current values of about $56 \%$ to about $64 \%$, and 2) the mined-out areas can be backfilled from the surface with FCPW-, gob-, and CCBs- based backfills containing 65\%-70\% solids that will minimize short-term and long-term surface movement and acid-mine drainage potential, and 3) grout may be expected to flow 300 feet or more depending upon sheer stress of the grout. All demonstration studies were performed at Crown III mine near Springfield, Illinois.

Crown III mine of Freeman United coal company is currently mining $600 \mathrm{ft}$ wide panels with 11 entries on $60 \mathrm{ft}$ centers with $20 \mathrm{ft}$ wide entries, and extraction ratio of $50 \%$ to $55 \%$. Coal is extracted from the No. 6 coal seam at a depth of 300 to $350 \mathrm{ft}$. The panels vary in length from $3,000 \mathrm{ft}$ to $5,000 \mathrm{ft}$. Seam height is seven feet and the weak floor strata are 2 to $4.5 \mathrm{ft}$ weak claystone. The dip of the coal seam is about $1.6 \%$ in the southeast direction.

The mining company developed a small panel (hereafter called the backfilling panel) with eight entries and $80 \mathrm{ft}$ by $60 \mathrm{ft}$ pillar sizes (center-to-center). The entry width in the backfilling panels was $20 \mathrm{ft}$. Secondary mining was done in this panel to increase the extraction ratio to $64 \%$ from about $55 \%$. In November 1997, three rows of pillars in the backfilling panel were notched to a depth of $20 \mathrm{ft}$ by two cuts of $18 \mathrm{ft}$ wide in each pillar. 
In and around the demonstration panel, roof-to-floor convergence and surface subsidence data were collected periodically. Measurements taken on March 23, 1999, in the backfilling panel indicated about 1.8 inches of convergence at the center of the panel. Roof falls were observed at a few intersections and as a result some of the measuring stations were destroyed. Due to this reason and also due to safety concerns, no underground measurements were taken after this date. However, surface deformations of monuments along several subsidence grids were measured periodically. It was found that, on the average, surface deformations of about 1.16 inch occurred during the last one year.

Two steel-cased injection holes (6-inch inside diameter) were utilized to inject paste backfill in the panel. A concrete mixing plant was built to mix crushed gob, FBC fly ash, and F-type fly ash with water. Several preliminary mixes were developed using gob and FBC fly ash and F-ash. Their engineering properties were developed and documented. Two mixes were selected for underground demonstration purposes, one having $25 \%$ gob, and the other having $40 \%$ gob in the mix.

In order to demonstrate the flow characteristics of selected mixes a trench was dug on the surface with two perpendicular crosscuts. The trench was about $100 \mathrm{ft}$ long, $9 \mathrm{ft}$ wide and 6-10 ft deep. On August 9, 1999, the mix with 40\% gob was pumped into this trench to observe the flow behavior. The mix flowed in all directions after discharge with little separation of water and solid components. It was also found that the mix flowed under water without much separation.

Due to the labor strike at Crown III mine, no progress was made in the field demonstration of underground backfilling until February 1999. Underground observations in March and borehole camera survey by the Office of Surface Mining (OSM) on July 7, 1999 showed that both the injection holes were open for backfilling. In the first (primary) hole, the camera was lowered to the mine floor level and the distances of coal pillars from the borehole were measured. There was a roof fall underneath the second (alternate) injection hole area. However, it was found that the entries in three directions were open from that borehole.

After two days of preparation, Phase I underground placement was started at 7:00 a.m. on August 11, 1999 through the first (primary) hole and the operation ended on September 8, 1999. About 8,159 tons of mix were pumped underground through the primary hole (5,873 ton of solid and 2,286 ton of water). The daily average backfilling rate of mix was 627 tons (452 ton of solid and 175 ton of water). The average water to solids ratio was about $40 \%$. With this ratio, 11-inch slump for the mix was achieved. The average hourly pumping rate of the mix was 117.1 tons/hour (83.5 ton/hour of solid and 33.6 ton/hour of water).

On August 24, 1999, an underground visit of the backfilling panel revealed that the mix had flowed a considerable distance (about $120 \mathrm{ft}$ ), as expected. It was found that the flow pattern was sheet-like and uniform in all directions. The gradient of the backfilled material underground was $1 \mathrm{ft}$ from the roof in all directions, 30- $\mathrm{ft}$ from the point of discharge. The backfilling operation was continued after that period. Mining Company 
staff visited the backfilled area again and found that the backfill had flowed about $300 \mathrm{ft}$ from the primary borehole. During the early part of October the backfilling panel was sealed off under instructions from MSHA and another underground visit was not possible.

During the Phase I backfilling operation, cylindrical samples (3-inch diameter and 6-inch long) were prepared for testing for compressive strength, elastic modulus, slake durability, swelling strain and hydraulic conductivity of the cured backfill. In order to perform a sensitivity analysis of these results, five new mixes similar to the field mix were prepared in the laboratory by slightly varying the proportion of each mix component. For each mix, three (3) cylindrical samples were prepared to obtain average results. It was found that the average strength and elastic modulus after 28-day curing were 190 psi and 17,960 psi, respectively. Similar values after 90-day curing were 334 psi and 40,445 psi, respectively. After about 540 days of curing, the values are about 550 psi, and 56,000 psi, respectively.

Slake durability index (second cycle) for field and laboratory samples ranged from 75 to $89 \%$, and 79 to $92 \%$, respectively. Swelling strain for field and laboratory samples ranged from 6 to $10 \%$, and 7 to $15 \%$, respectively. Samples for testing hydraulic conductivity could not be prepared at Crown III mine site but were made in the laboratory. For pressure head between 30 to $50 \mathrm{psi}$, hydraulic conductivity varied from 0.01 to 0.06 inch/day. Thus, the backfilled material underground has very low permeability.

On October 13, 1999 backfilling operation resumed through the second (alternate) borehole. A concrete pump was used to pump the mix from the concrete plant site to this hole, a distance of about $250 \mathrm{ft}$. After four days of operation, 1,134 ton of solid and water (773 ton solid and 361 ton of water) was backfilled underground. Altogether using both boreholes, 9,293 ton of material was injected underground.

On September 18, 2000, a borehole camera survey was conducted again in the second borehole in cooperation with OSM to observe the underground conditions in the vicinity of the borehole. It was found that entries in the south, west and east directions were open. No new roof falls had occurred in this intersection. Thus, Phase II backfilling operation (through second hole) resumed on September 27, 2000. This time, a highspeed auger mixer was used to mix solids and water and then inject them underground as a paste backfill. This mix was composed of F fly ash and FBC fly ash. These two ashes were premixed in 1:2 ratio ( $\mathrm{F}$ to $\mathrm{FBC}$ ash) by weight and dumped into a hopper using a front-end-loader. Water was added at the rear end of the auger mixer and grout mix came out from the front end (borehole side). As of October 30, 2000, about 6,000 tons of grout were injected through the second hole with a water to powder ratio of 0.47 . It is estimated that the injected grout filled over 140,000 $\mathrm{cft}$ of underground voids. The injected grout filled about $900 \sim 1,000 \mathrm{ft}$ of mine voids assuming average entry width and opening height of $20 \mathrm{ft}$ and $7 \mathrm{ft}$, respectively. During this operation several 3x6 inch cylindrical samples were prepared for obtaining the compressive strength and elastic modulus of the injected grout. 
The ASTM shake test was performed for the field backfill mixes. It was found that the mixes were environmentally benign. The $\mathrm{pH}$ of the leachate was 11.23 , with $\mathrm{Ca}$ concentration of $669 \mathrm{ppm}$, and $1540 \mathrm{mg} / \mathrm{l}$ of dissolved solids. The concentration of most of the heavy trace elements was below the Class I ground water (GW) standard.

Strength and elastic modulus data from laboratory and field samples were analyzed using linear regression models. It was found that the ratio of the proportion between FBC ash and water content is the most important parameter for determining 7-day and 28-day cured strength and elastic modulus of mixes. The ratio between F ash and FBC ash also plays an important role in estimating 7-day compressive strength. These relationships were verified with the samples (similar to field samples) prepared in the laboratory. This analysis provides a mathematical foundation for forecasting strength and elastic modulus of samples composed of FBC ash, F-ash, gob and water.

The effect of backfilling on the stability of the mine workings was analyzed using SIUPANEL.3D computer program and further verified using finite element analysis techniques. Stiffness of the backfill mix is most critical for enhancing the stability of mine workings. Mine openings do not have to be completely backfilled to enhance their stability. Backfill height of about $50 \%$ of the seam height is adequate to minimize surface deformations.

The cooperating mining company performed engineering economic evaluation studies for commercial implementation of the concepts demonstrated. The company also sought input from an independent consultant regarding use of this technology at Crown III mine. The results indicate that underground management cost is comparable, but slightly higher, to that for surface management techniques currently practiced at the mine. The decision to implement underground management concepts must however be made on a site-specific basis. Underground management minimizes the capital cost for disposal ponds and closure costs for the ponds. However, the processing plant must be modified for alternate handling of refuse. Underground management also requires capital for mixing solids with water and the transportation of paste backfill to the borehole. Overall, economic evaluation studies indicate that this alternate underground management technology has potential for commercial implementation but it favors new mines with long life.

An economic evaluation of mine backfilling in this and earlier studies indicates that the amount of grout injected through each borehole is an important variable. This is particularly true where prime agricultural lands are involved, since the land acquisition and reclamation costs are very high. Therefore, a thorough understanding of grout flow in underground partial extraction mine workings is extremely important. Stiles (1999) of West Virginia University developed an approximate mathematical model of grout flow in room-and-pillar mine workings. Therefore, grout flow simulation was undertaken to develop a better understanding of grout flow in room-and-pillar coal mine workings typically encountered in Illinois. The overall goal of this task was to develop a better understanding of grout flow phenomenon in flat and slightly pitching coal seams and 
relative importance of variables, such as grout yield stress, grout hardening, and slope of the coal seam. Overall, the simulation results compared favorably with the experience in the field.

In summary, the project was successful in achieving its objectives. Underground placement of paste backfill mixes technology has been developed and demonstrated successfully for industry use. 


\section{TABLE OF CONTENTS}

Acknowledgements

Disclaimer Statement

Abstract

Executive Summary

Table of Contents

List of Figures

List of Tables

I. Introduction and Background

II. Goals and Objectives

III. Experimental Procedures, Results and Discussion

- Demonstration Mine Characteristics

- Charactaristics of the Backfilling Demonstration Area

- Surface and Underground Geotechnical Studies

o Underground Visit

o Surface Vertical Movements, Underground Convergence

- Mix Development and Selection of Backfilling Mixes

o Final Mixes Selection

o Development of Additional Mixes Similar to the Field Mix

- Construction of Mixing Plant at Crown III Mine

- Surface Demonstration of Field Mix Flow Characteristics

- Borehole Camera Survey

- Field Demonstration of Underground Backfilling Using the Mixing Phant - Phase II (First Borehole)

- Underground Backfill Flow Characteristics

- Field Demonstration of Underground Backfilling Using a High-Speed Auger MixerPhase II (Second Borehole)

o High-Speed Auger Mixing Plant

o Underground Backfilling Operation Through Second Borehole

26

o Backfill Flow Characteristics

- Engineering Properties of the Field Mixes Recovered During Field Demonstration

- Slake Durability

- Swelling Strain

- Permeability or Hydraulic Conductivity

- Comparison of Compressive Strength and Elastic Modulus for Field Samples and Developed Statistical Model from Laboratory Samples

- Trace Element Concentration in Field Mix Leachate 
IV. An Analysis of the Effect of Backfilling on Weak Floor and Coal Pillar Stability

- Analytical Studies

o SIUPANEL3D Analytical Model

o Model Validation

- Validation of Modeling Hypothesis Through Finite Element Analysis

o Analysis Methodology

45

o Results and Discussions

V. Engineering Economic Analysis

- Results of Engineering Economic Analysis

VI. Grout Flow Simulation in Underground Mine Workings

- Introduction

- Task Objectives

- Groutnet Mathematical Simulation Model

52

- Description of the Developed Models

- Results and Discussion

57

o Single Entry Analysis Results

Calibration of the Model

- Effect of Channel Floor Slope

58

- Effect of Grout Hardening

61

o Three Entry Analysis Results

62

o Crown III Mine Analysis Results

VII. Conclusions and Recommendations

- Conclusions

70

- Recommendations

VIII. References 


\section{LIST OF FIGURES}

Figure Page

No. Description No.

$1 \quad$ Panel geometry in the proposed backfilling areas. 5

2 Locations of the underground convergence stations. $\quad 7$

$3 \quad$ Surface deformation over the backfilling panel. 8

4 Roof-to floor convergence along GG' line. 8

5 Roof-to-floor convergence along HH' line. 9

6 Gob particle size distribution for laboratory and field samples. 10

$7 \quad$ Relationship between 7-day compressive strength and FBC/WATER ratio. 14

$8 \quad$ Relationship between 7-day elastic modulus and FBC/WATER. 15

9 Relationship between 28-day compressive strength and FBC/WATER $\begin{array}{ll}\text { ratio. } & 16\end{array}$

10 Relationship between 28-day elastic modulus and FBC/WATER. 17

11A A view of the mixing plant. 19

11B Another view of the mixing plant. $\quad 19$

12A Schematics of the surface trench. 21

12B Picture of the surface trench. 21

13 Borehole camera survey. 22

14 Daily backfilling rate through primary borehole (Phase I). 23

15 Daily backfilling rate through the secondary borehole (Phase I). 24

16 Underground condition of the panel after backfilling. 25

17 Backfilling operation using auger mixer. 27

18 Daily backfilling rate using secondary borehole (Phase II). 28

19 Stress strain relationship for field samples for different curing times. 29

20 Comparison of slump vs. bleed for laboratory and field. 30

21 Variation in slake durability index with FBC/WATER ratio. 31

$22 \quad$ Variation in swelling strain with FBC/WATER ratio. 32

23 Variations in hydraulic conductivity with FBC/WATER. 32

24 A schematic diagram depicting stress redistribution due to backfilling (A and $\mathrm{B}=$ before backfilling; $\mathrm{C}=$ after backfilling). 38

25 Mohr's circle for a theoretical backfill material. 39

26 Room-and-Pillar mining geometry for the validation mine 41

27 Influence of backfill height on failure probability of pillar 24.

28 Variation of pillar and floor factor of safety with the backfill height. 42

29 Variation of floor bearing capacity with backfill height. 43

$30 \quad$ Variation of pillar and floor safety factors in a panel without backfilling. 44

$31 \quad$ Variation of pillar and floor safety factors in a panel after backfilling. 44

32 The contour of major principal stress $\left(\sigma_{1}\right)$ at four different stages. 47

33 The contour of minor principal stress $\left(\sigma_{3}\right)$ at four different stages. 47

34 The effect of modulus ratio on floor safety factors. 48

35 Physical channel (A) and its Groutnet equivalent model (B) for the singleentry system. 
36 Physical channel (A) and its Groutnet equivalent model (B) for the threeentry system.

37 The Crown III room and pillar mine (A) and its Groutnet equivalent model (B) for grout flow analysis.

38 Grout profile of $5 \frac{1}{2}$ days of grout injection at $0 \%$ slope. 57

39 Grout profile after $5 \frac{1}{2}$ days of grout injection at $1 \%$ slope. 58

40 Grout profile of $5 \frac{1}{2}$ days of grout injection at 120 tons/hour pumping rate $\left(0.0176 \mathrm{~m}^{3} / \mathrm{s}\right)$.

41 Grout profile of $51 / 2$ days of grout injection at 150 tons/hour pumping rate $\left(0.02152 \mathrm{~m}^{3} / \mathrm{s}\right)$.

42 Grout profile of $5 \frac{1}{2} 2$ days of grout injection at 200 tons/hour pumping rate $\left(0.0286 \mathrm{~m}^{3} / \mathrm{s}\right)$.

43 Amount of grout used vs. rate of pumping.

44 Amount of grout used vs. traveled distance of the grout.

45 Grout profile for the grout hardening (the grout starts hardening at the end of third day).

46 Flood map of grout profile after 12 hours and 1 minute of grout injection.

47 Flood map of grout profile after 1 day 15 hours 2 minutes and 15 seconds of grout injection.

48 Flood map of grout profile after 10 days 18 hours 12 minutes and 24 seconds of grout injection.

$49 \quad$ Flood map of grout profile after 1 day of grout injection. 64

$50 \quad$ Flood map of grout profile after 2 days of grout injection. $\quad 64$

$51 \quad$ Flood map of grout profile after 3 days of grout injection. 65

$52 \quad$ Flood map of grout profile after 4 days of grout injection. 65

$53 \quad$ Flood map of grout profile after 5 days of grout injection. 66

$54 \quad$ Flood map of grout profile after 6 days of grout injection. 67

$55 \quad$ Flood map of grout profile after 7 days of grout injection. 67

56 Flood map of grout profile after 10 days of grout injection. 68

57 Flood map of continuous grout injection after 5days 1 hour 18 minutes and 28 seconds of grout injection. 


\section{LIST OF TABLES}

Table

No. Description

Page

$1 \quad$ Studies related to filling underground voids.

No.

2 Laboratory data for Mix Design.

2

3 Proportions of raw ingredients of four final mixes.

$4 \quad$ Engineering properties of the final mixes. 17

$5 \quad$ Proportions of additional mixes similar to the field mix. 18

$6 \quad$ Characteristics of conveyor belts. 18

$7 \quad$ Adjusting the speed of conveyor belt based on water feed rate. 27

8 Engineering properties of field samples. 30

9 Compressive strength of 90-day cured field samples. 30

10 Actual compressive strength and elastic modulus of 18-month (560 days) cured field samples.

11 Actual and predicted compressive strength and elastic modules of 7-day cured field samples.

12 Actual and predicted compressive strength and elastic modules of 28-day 34 cured field samples.

13 Elemental concentrations (in ppm) in the leachate of ASTM shake test. 35

14 Input parameters for probabilistic analysis. 40

15 Capital cost requirements for backfilling project 50

16 Breakdown of operating costs 50

17 Material properties of the injected grout. 55 


\section{INTRODUCTION AND BACKGROUND}

The history of mining is replete with many instances of backfilling to make a safe underground mining environment, control subsidence and increase coal extraction. Table 1 summarizes some of these studies conducted in the USA and abroad. Conclusions derived from earlier studies reported in Table 1 are summarized below.

i) In the USA, most backfilling has been done in abandoned coal mines to control surface subsidence. In addition, underground backfilling with mine tailings was done in deep silver and gold mines to enhance recovery and profitability.

ii) Underground backfilling was done mostly using low solid content slurry. Paste backfilling is an emerging technology, which offers higher economic and environmental advantages than the slurry backfill system (Brackebusch, 1994).

iii) Instances of systematic mix development to engineer a paste of appropriate structural and environmental characteristics are few and far between. Most systematic mix development procedures were directed towards developing flowable fills except a paste development study by the PI (Chugh et al., 1996c).

iv) Instances of integrated environmental studies in conjunction with backfilling are very few.

v) Engineered mixes were never developed to alter leaching behavior of individual components.

vi) Integrated approach to manage FCPW, gob, and CCBs to decrease disposal costs and enhance recovery has never been attempted.

The PI has addressed some of the above issues in developing and demonstrating the feasibility of a paste backfill system using various coal related by-products. For instance, in the project contracted by the DOE, environmentally benign and structurally appropriate grouts have been developed with $70 \%$ to $75 \%$ solids and pumped in an abandoned underground mine using a concrete pump (Chugh et al., 1996b). In the project funded by the ICCI, leaching behavior of individual grout components (FCPW and $\mathrm{CCBs}$ ) has been altered to produce an environmentally benign paste with $60 \%$ to $65 \%$ solids and no visible bleed off water. The paste which had ASTM slump of 4 to 6 inches was pumped on the surface over a distance of approximately $450 \mathrm{ft}$ through sixinch diameter steel pipes (Chugh, et al., 1996a).

The system developed under the U.S. Department of Energy grant (100 tons/hour) has been successfully demonstrated on the surface and for backfilling an abandoned underground mining panel. To the best of the authors' knowledge, paste backfilling in an active underground coal mine has not been demonstrated in the USA. The coal companies contacted believe that paste backfilling has the potential to enhance mining economics. However, backfilling capabilities and effectiveness must be demonstrated in an active mine before coal companies can seek permits for mining plans with backfill. 
Table 1. Studies related to filling underground voids.

\begin{tabular}{|c|c|c|}
\hline Authors and Sources & Backfilling Reason & Comments \\
\hline Carlson (1975) & Subsidence control & Model studies. \\
\hline Maser et al. (1975) & Subsidence control & Fly ash-cement mine sealant. \\
\hline Whaite and Allen (1975) & Subsidence control & Slurry backfill. \\
\hline $\begin{array}{l}\text { Galvin and } \text { Wagner } \\
(1982)\end{array}$ & Enhance extraction & $\begin{array}{l}\text { South African coal mines to } \\
\text { increase extraction by } 8 \%- \\
12 \% \text {. Fly ash only. }\end{array}$ \\
\hline Petulanas (1988) & Subsidence control & $\begin{array}{l}\text { High volume use of fly ash in } \\
\text { underground void filling. } \\
\text { Low solid density mixes. }\end{array}$ \\
\hline Palarski (1993) & Enhance extraction & $\begin{array}{l}\text { In Polish coal mines. Fly ash, } \\
\text { tailings, rocks. }\end{array}$ \\
\hline $\begin{array}{l}\text { Hollinderbaumer and } \\
\text { Kramer (1994) }\end{array}$ & $\begin{array}{l}\begin{array}{l}\text { Subsidence } \\
\text { ground control }\end{array} \\
\text { and }\end{array}$ & $\begin{array}{l}\text { Integrated approach in } \\
\text { German longwall mines to } \\
\text { dispose of incinerator ash. }\end{array}$ \\
\hline Meiers, et al. (1995) & Subsidence control & Fly ash-scrubber sludge mix. \\
\hline Gray et al. (1995) & $\begin{array}{l}\text { Acid Mine Drainage } \\
\text { control }\end{array}$ & Disposal of FBC. \\
\hline Chugh (1996c) & $\begin{array}{l}\text { Acid Mine Drainage } \\
\text { control }\end{array}$ & $\begin{array}{l}\text { Fly ash, scrubber sludge- } \\
\text { based pastes pumped into an } \\
\text { abandoned Maryland mine. }\end{array}$ \\
\hline Chugh et al (1996b) & Subsidence Control & $\begin{array}{l}\text { Fly ash and scrubber sludge } \\
\text { pastes pumped into an } \\
\text { abandoned mine panel in } \\
\text { Illinois. }\end{array}$ \\
\hline
\end{tabular}

The thrust of the current project was to develop and demonstrate the feasibility of pumping backfill material in an active mine to enhance mining economics by recovering more coal and increasing productivity. 


\section{GOALS AND OBJECTIVES}

The goal of this project was to demonstrate that coal processing waste and CCBs-based paste backfill can be managed underground, which can increase extraction ratio, decrease production cost, and enhance the environment. The more specific objectives of the project are to:

1. Demonstrate that environmentally benign pumpable paste backfill mixtures containing $55 \%$ to $60 \%$ solids can be developed using FCPW (fine coal processing waste or coal slurry), gob, and CCBs (coal combustion by-products).

2. Demonstrate that the reduction of pillar sizes is possible without affecting the surface if the panel is subsequently backfilled.

3. Demonstrate that gob- and CCB-based high-density paste backfill can flow at least 300 feet from the injection borehole.

4. Study flow characteristics of paste backfill in entries and crosscuts during the pumping process and evaluate the extent to which entries and crosscuts are fully backfilled away from the injection point.

5. Study shrinkage, durability, and strength-deformation properties of the pumped backfill as curing progresses.

6. Study impacts of backfilling on surface movements.

Perform cost studies for paste backfill placement in an active mine. 


\section{EXPERIMENTAL PROCEDURES, RESULTS AND DISCUSSION}

\section{- Demonstration Mine Characteristics}

The backfilling demonstration was conducted at Crown III mine of Freeman United Coal Company near Farmersville, IL. Crown III mine is currently mining $600 \mathrm{ft}$ wide panels with 11 entries on $60 \mathrm{ft}$ centers with $20 \mathrm{ft}$ wide entries. Coal is extracted from No. 6 coal seam at a depth of 300 to $350 \mathrm{ft}$. The panels vary in length from 3,000 ft to 5,000 ft. Seam height is seven feet. The floor is $24.5 \mathrm{ft}$ thick weak claystone and is dipping approximately $1.6 \%$ in the southeast direction of the panel.

\section{- Characteristics of the Backfilling Demonstration Area}

Figure 1 shows the panel under study. Mining was done in the regular panel which was $600 \mathrm{ft}$ wide. After mining had progressed $2860 \mathrm{ft}$, bad roof conditions due to local geologic anomalies were encountered. To improve the roof conditions, pillar dimensions were changed from $40 \mathrm{x} 40 \mathrm{ft}$ to $60 \mathrm{x} 40 \mathrm{ft}$ (as shown in Figure 1). For the purpose of the demonstration, the mining company developed the backfilling panel (shown in Figure 1) with eight entries and $60 \mathrm{ft}$ by $40 \mathrm{ft}$ pillar sizes. The entry width in both the regular and the backfilling panels was $20 \mathrm{ft}$. In the backfilling panel, secondary mining was done to increase the extraction ratio to $65 \%$ from 50-55\%. Three rows of pillars in the backfilling panel were extracted to a depth of $20 \mathrm{ft}$ by two cuts of $18 \mathrm{ft}$ wide in each pillar.

\section{- Surface and Underground Geotechnical Studies}

Rock mechanics studies involved underground visits prior to and after secondary mining in the backfilling panel, plate loading tests in a typical panel of regular geometry to estimate floor bearing capacity, installation of underground convergence points and surface movement monitoring stations, data collection from the monitoring stations, floor and pillar safety factor analyses for different pillar geometries and numerical modeling for predicting surface movements and pillar and floor stability. Four plate loading tests and assessment of floor safety factors and surface vertical movements by SIUPANEL.3D model were also performed.

Underground Visit: During a visit to the backfilling panel in December 1997, the mining areas were found to be stable throughout. Localized roof falls due to geologic anomalies were observed in one pillar extraction cut. Rib sloughing in the backfilling panel was no different than in the areas where no pillar extraction was done (in the regular panel). Roof bolts in general did not indicate signs of significant loading and all intersections were found stable. No floor heave was observed in any area. However, the last underground visit on March 23, 1999 showed different conditions of the roof and the floor. However, roof falls in a few intersections are considered normal at this mine for the geologic conditions present even without the higher extraction implemented in the demonstration area. Roof falls occurred in a few intersections with high volume of rock debris on the floor. A few measuring stations were destroyed due to roof falls. Rib failures were also visible in some coal pillars. 


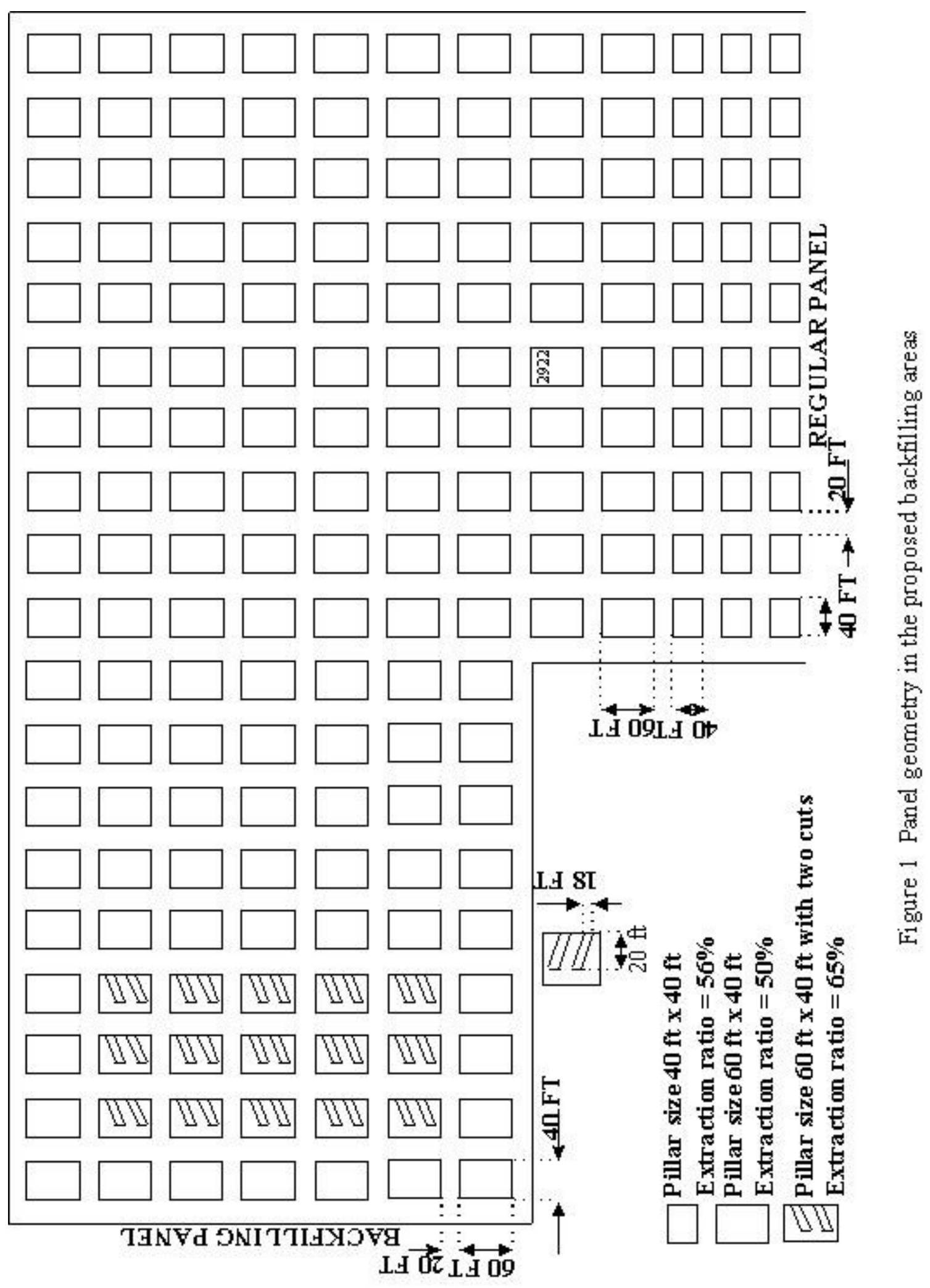


Surface Vertical Movements, Underground Convergence: The surface vertical movements monitoring network and the underground convergence stations are shown in Figure 2. Surface movement stations along line A-A', B-B' and C-C' were installed at variable intervals. A surface movement station consisted of a 7-ft long frost-free design roof bolt of 7/8-inch in diameter. The roof bolts were inserted into the ground to a depth of 5.5 to $6.0 \mathrm{ft}$. The top three feet of the bolt in the ground was surrounded by closed-cell foam insulation and a PVC pipe. An auto-set level was used to record the levels of the bolt heads.

Surface deformation was measured along X-X' line until March 2, 1998 (Figure 2). However, these deformation points were lost due to equipment movements, digging of the surface trench and dumping of coal combustion by-products. So, new points were established along A-A', B-B' and C-C' lines. Elevations of these points were measured in August 1998, March 1999 and again on August 12, 1999. It was found that average movement of the backfilling area was little over 1.16 inch for the last year and occurred uniformly downward over the entire area. Figure 3 shows the surface deformation along A-A', B-B' and C-C' lines. The maximum deformation of 1.8 inch was recorded around the primary borehole area. However, no differential ground settlement occurred over the backfilling area.

Underground convergence stations numbered G1 through G7 and H1 through $\mathrm{H} 7$ were monitored periodically to measure underground movements. A convergence station consisted of a roof bolt head and a square-head bolt, vertically beneath the roof bolt, anchored into the floor. It is designed to measure the roof-to-floor convergence using a convergence rod. Underground roof-to-floor convergence monitoring was carried out until March 23, 1999. Some of the convergence stations were damaged due to roof falls and reaching other measuring stations became unsafe. As a result, the underground monitoring program was abandoned.

Underground observation of the study area in March 1999 revealed that roof falls had occurred in a few intersections. In some cases, it was impossible to measure the height of debris fallen on the floor. Wherever possible roof-to-floor convergence data was collected from the underground measuring points to evaluate condition of entries in the study area. In some areas, about 1.8 inches of roof-to-floor movements were recorded. Figures 4 and 5 indicate the roof-to-floor convergence along GG' and HH' lines, respectively measured over the two-year period. Some underground areas were inaccessible due to roof falls. In general, the backfilling area was unsafe for traveling. 


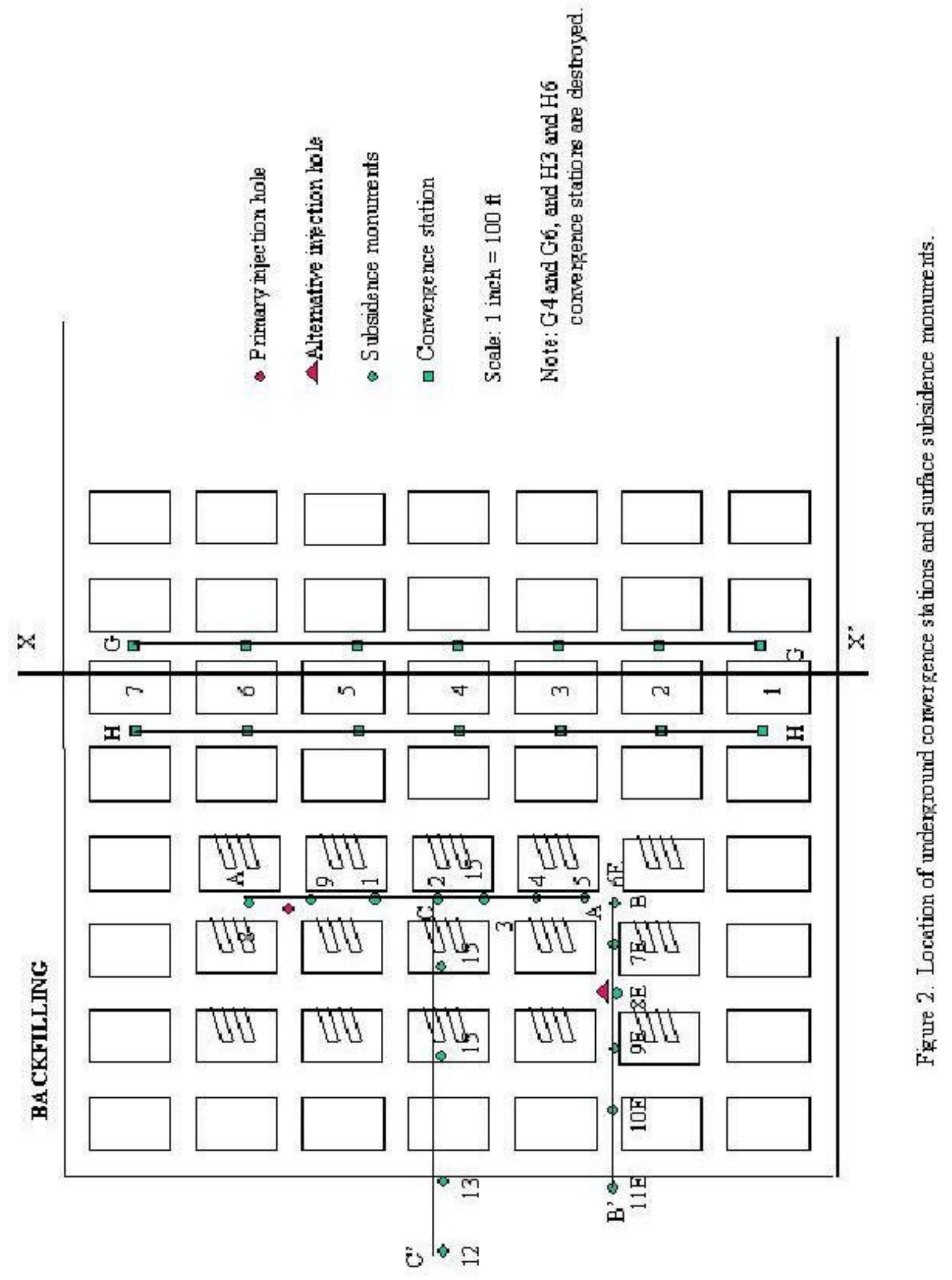




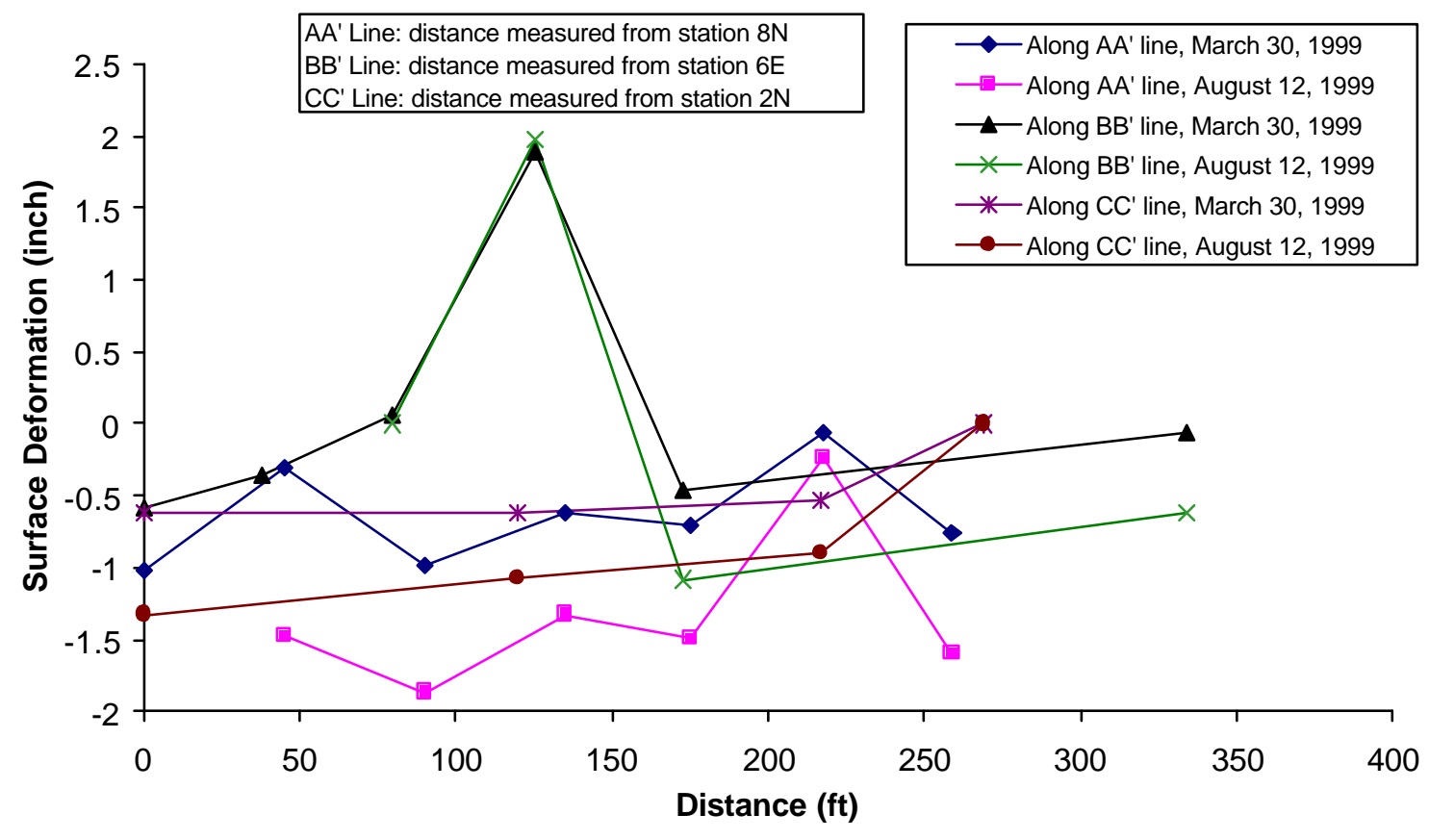

Figure 3. Surface deformation over the backfilling panel.

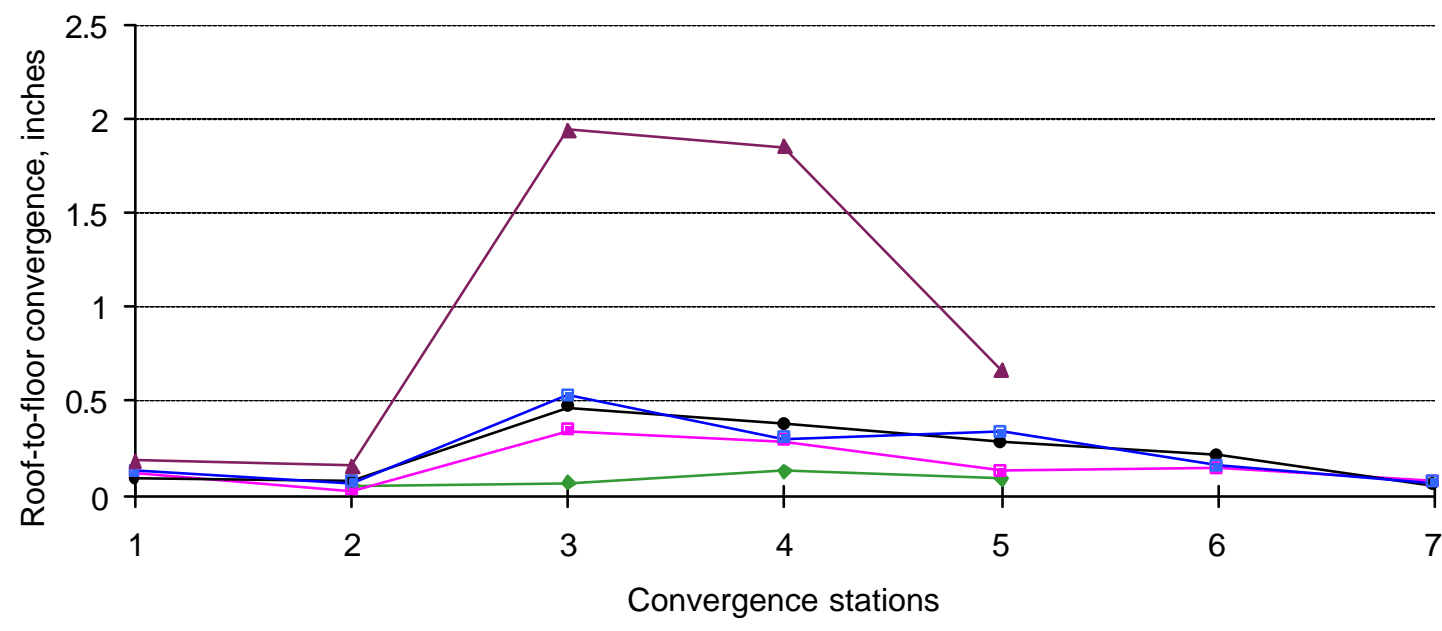

$\multimap$ November 19, $1997 \multimap$-January 19, $1998 \multimap$ May 11, $1998 \multimap-$ June 30, $1998 \multimap$ March 23,1999

Figure 4. Roof-to floor convergence along GG' line. 


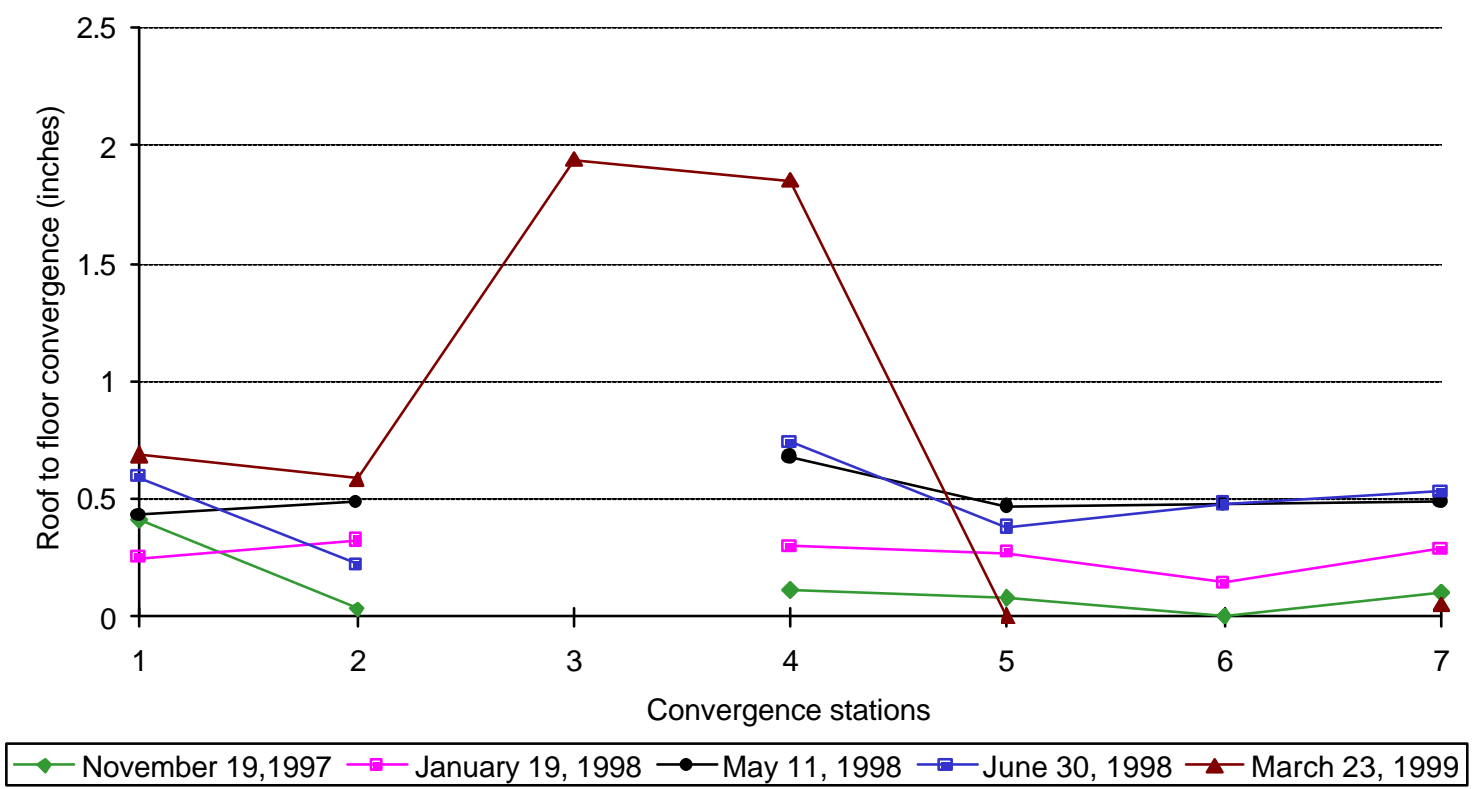

Figure 5. Roof-to-floor convergence along HH' line.

\section{- Mix Development and Selection of Backfilling Mixes}

One of the objectives of this project was to develop a backfill material with sufficient strength and stiffness that can enhance underground mine stability, and minimize additional ground movements. Compressive strength and elastic modulus of the backfill material are considered most important engineering properties. Therefore, laboratory studies were conducted to identify the most significant variables that dominate the outcome of these two engineering properties. For Illinois Basin mines, hydraulic conductivity, swelling strain and durability properties are also considered important since a weak claystone layer exists in the floor. The backfill material should behave as an impermeable layer with the maximum durability index.

Crown III mine supplied gob (coarse coal refuse of coal processing rejects) and FBC fly ash. As the sizes of gob varied between -4 inches to +28 mesh, the as-received gob was crushed to sizes less than 0.25 inches. Particle size distribution for gob is given in Figure 6. F-type fly ash was obtained from the Coffeen power plant. The moisture content of the as-received materials, particle sizes and calcium carbonate equivalent (CCE) values of the raw materials (gob, FBC and F-type fly ash) were determined. Mix development and selection of final mixes were reported earlier (Chugh et al, 1998). However, in the field demonstration, gob was crushed to a maximum size of $0.75 \mathrm{inch}$. Thus, gob particle size distribution in the field was slightly different from that of laboratory tests (Figure 6). 


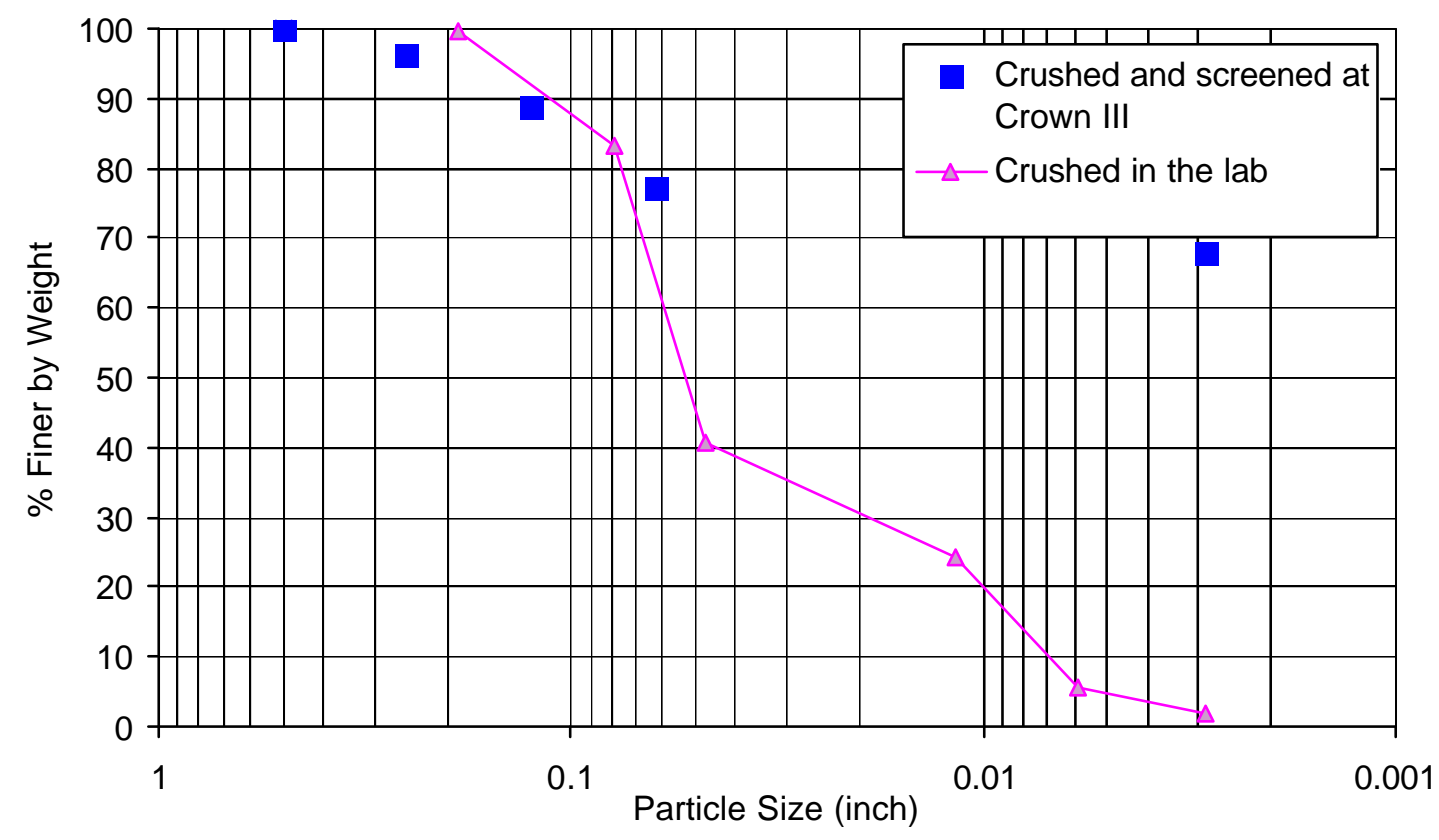

Figure 6. Gob particle size distribution for laboratory and field samples.

In the laboratory, about 20 different mixes were prepared using F-ash, FBC ash, gob and water to achieve a slump height between 9 to 11 inches. For each mix, at least three samples were prepared and tested for 7-day and 28-day strength and elastic modulus as given in Table 2. These data were analyzed using linear regression models with two independent variables such as FBC/Water and F/FBC, and 95\% confidence level. Here, $\sigma$ and $\mathrm{E}$ refer to the compressive strength and elastic modulus, respectively and suffix 7 and 28 refer to the number of curing days. In general, a two variable linear statistical model is given in the following equation:

$$
y=\beta_{0}+\beta_{1} x_{1}+\beta_{2} x_{2}
$$

where,

$\mathrm{y}$ is dependent variable such as strength or elastic modulus

$\mathrm{x}_{\mathrm{i}}(\mathrm{i}=1,2)$ are independent variables

$\beta_{\mathrm{i}}(\mathrm{i}=0,1,2)$ are parameters to be estimated from laboratory data regression analysis 
Table 2. Laboratory data for Mix Design.

\begin{tabular}{|c|c|c|c|c|c|c|}
\hline Sample & FBC/WATER & F-ASH/FBC & $\sigma_{7}, \mathbf{p s i}$ & $\mathbf{E}_{7}, \mathbf{p s i}$ & $\sigma_{28}, \mathrm{psi}$ & $\mathrm{E}_{28}, \mathrm{psi}$ \\
\hline 1 & 1.56 & 0.00 & 323 & 18700 & 484 & 21667 \\
\hline 2 & 1.56 & 0.00 & 214 & 16500 & 392 & 21010 \\
\hline 3 & 1.56 & 0.00 & 299 & 16757 & 523 & 29857 \\
\hline 4 & 1.19 & 0.00 & 224 & 21544 & 384 & 21468 \\
\hline 5 & 1.19 & 0.00 & 187 & 16250 & 299 & 22510 \\
\hline 6 & 1.19 & 0.00 & 187 & 14500 & 424 & 29032 \\
\hline 7 & 0.61 & 0.00 & 56 & 11085 & 150 & 12500 \\
\hline 8 & 0.61 & 0.00 & 77 & 12339 & 168 & 10800 \\
\hline 9 & 0.61 & 0.00 & 93 & 7164 & 149 & 10500 \\
\hline 10 & 1.00 & 0.25 & 131 & 11251 & 423 & 23855 \\
\hline 11 & 1.00 & 0.25 & 130 & 12875 & 392 & 26087 \\
\hline 12 & 1.00 & 0.25 & 187 & 15640 & 299 & 17857 \\
\hline 13 & 1.22 & 0.67 & 218 & 20850 & 356 & 21088 \\
\hline 14 & 1.22 & 0.67 & 265 & 13424 & 392 & 25000 \\
\hline 15 & 1.22 & 0.67 & 178 & 14330 & 448 & 26157 \\
\hline 16 & 1.22 & 0.67 & 299 & 19000 & 523 & 19230 \\
\hline 17 & 1.22 & 0.67 & 224 & 25000 & 392 & 24000 \\
\hline 18 & 1.22 & 0.67 & \begin{tabular}{|l|}
187 \\
\end{tabular} & 15799 & 392 & 25455 \\
\hline 19 & 0.35 & 1.00 & 50 & 8440 & 84 & 7037 \\
\hline 20 & 0.35 & 1.00 & 56 & 5125 & 93 & 7603 \\
\hline 21 & 0.35 & 1.00 & 75 & 4800 & 112 & 8007 \\
\hline 22 & 0.76 & 1.20 & 168 & 13131 & 298 & 15257 \\
\hline 23 & 0.76 & 1.20 & 155 & 12727 & 187 & 12727 \\
\hline 24 & 0.76 & 1.20 & 112 & 10020 & 205 & 22727 \\
\hline 25 & 0.30 & 4.00 & 93 & 7463 & 131 & 11429 \\
\hline 26 & 0.30 & 4.00 & 149 & 8333 & 149 & 12800 \\
\hline 27 & 1.11 & 0.50 & 143 & 14552 & 399 & 22222 \\
\hline 28 & 1.11 & 0.50 & 168 & 18300 & 348 & 29167 \\
\hline 29 & 1.35 & 0.20 & 221 & 16580 & 392 & 30125 \\
\hline 30 & 1.35 & 0.20 & 188 & 14045 & 467 & 24070 \\
\hline 31 & 1.35 & 0.20 & 256 & 23667 & 485 & 27631 \\
\hline 32 & 1.35 & 0.20 & 199 & 20048 & 486 & 26000 \\
\hline 33 & 1.35 & 0.20 & 243 & 22580 & 299 & 25000 \\
\hline 34 & \begin{tabular}{|l|}
0.97 \\
\end{tabular} & 0.49 & 131 & 11875 & 429 & 24880 \\
\hline 35 & 0.97 & 0.49 & 195 & 16000 & 299 & 19900 \\
\hline 36 & 0.97 & 0.49 & 112 & 10800 & 429 & 21066 \\
\hline 37 & \begin{tabular}{|l|}
0.79 \\
\end{tabular} & 1.00 & 112 & 8400 & 354 & 28571 \\
\hline 38 & 0.79 & 1.00 & 142 & 10000 & 317 & 22857 \\
\hline
\end{tabular}




\begin{tabular}{|l|l|l|l|l|l|l|}
\hline \multicolumn{7}{|c|}{ Table 2 (contd.) } \\
\hline Sample & FBC/WATER & F-ASH/FBC & $\sigma_{7}, \mathbf{p s i}$ & $\mathbf{E}_{7}, \mathbf{p s i}$ & $\sigma_{\mathbf{2 8}}, \mathbf{p s i}$ & $\mathbf{E}_{\mathbf{2 8}}, \mathbf{p s i}$ \\
\hline 39 & 0.79 & 1.00 & 93 & 11857 & 355 & 21000 \\
\hline 40 & 1.41 & 0.00 & 168 & 20000 & 429 & 26617 \\
\hline 41 & 1.41 & 0.00 & 252 & 25080 & 504 & 30820 \\
\hline 42 & 1.41 & 0.00 & 168 & 18867 & 467 & 28502 \\
\hline 43 & 1.43 & 0.00 & 264 & 17640 & 504 & 31250 \\
\hline 44 & 1.43 & 0.00 & 193 & 19235 & 467 & 30000 \\
\hline 45 & 1.43 & 0.00 & 243 & 23168 & 505 & 35200 \\
\hline 46 & 0.69 & 1.00 & 144 & 10000 & 205 & 16755 \\
\hline 47 & 0.69 & 1.00 & 93 & 7550 & 224 & 22203 \\
\hline 48 & 0.69 & 1.00 & 88 & 7200 & 242 & 22982 \\
\hline 49 & 0.99 & 1.00 & 185 & 14600 & 392 & 19540 \\
\hline 50 & 0.99 & 1.00 & 205 & 12230 & 429 & 24500 \\
\hline 51 & 0.99 & 1.00 & 193 & 10000 & 355 & 26250 \\
\hline 52 & 1.56 & 0.20 & 254 & 26458 & 504 & 25000 \\
\hline 53 & 1.56 & 0.20 & 299 & 23875 & 467 & 22222 \\
\hline 54 & 1.56 & 0.20 & 348 & 25000 & 468 & 20550 \\
\hline 55 & 1.56 & 0.20 & 297 & 15540 & 504 & 30481 \\
\hline 56 & 1.56 & 0.20 & 212 & 17560 & 504 & 37500 \\
\hline 57 & 1.15 & 0.20 & 174 & 21450 & 430 & 23235 \\
\hline 58 & 1.15 & 0.20 & 212 & 20000 & 467 & 25309 \\
\hline 59 & 1.15 & 0.20 & 147 & 14222 & 392 & 27778 \\
\hline 60 & 1.15 & 0.20 & 168 & 13120 & 541 & 28035 \\
\hline 61 & 1.15 & 0.20 & 255 & 27778 & 542 & 28866 \\
\hline 62 & 0.98 & 0.38 & 119 & 12255 & 342 & 17950 \\
\hline 63 & 0.98 & 0.38 & 138 & 9927 & 256 & 21098 \\
\hline 64 & 0.98 & 0.38 & 142 & 10875 & 268 & 18760 \\
\hline 65 & 0.79 & 0.83 & 168 & 14830 & 317 & 21145 \\
\hline 66 & 0.79 & 0.83 & 168 & 15000 & 355 & 21080 \\
\hline 67 & 0.79 & 0.83 & 112 & 11800 & 280 & 17833 \\
\hline & & & & & & \\
\hline
\end{tabular}

In this case, $\beta_{0}$ is assumed to be zero because when all independent variables are zero, dependent variables such as strength and elastic modulus must be zero. Since sum of the proportion of three solid components is unity, the following statistical model was developed:

$$
\begin{aligned}
& \text { Strength }=\beta_{1}\left(\frac{F}{F B C}\right)+\beta_{2}\left(\frac{F B C}{\text { WATER }}\right) \\
& \text { Modulus }=\beta_{1}\left(\frac{F}{F B C}\right)+\beta_{2}\left(\frac{F B C}{\text { WATER }}\right)
\end{aligned}
$$


In these models, GOB proportion is indirectly included as a parameter since the sum of the proportions of $\mathrm{F}+\mathrm{FBC}+\mathrm{GOB}=1$. However, gob has a significant contribution in acid-base neutralization potential in the mix. In general, gob is acidic with a $\mathrm{pH}$ value of 2-4. On the other hand, FBC ash is alkaline and when gob is mixed with FBC in appropriate proportions, the $\mathrm{pH}$ of the mix may range between 7-8. Such a mix significantly reduces the possibility of acid mine drainage.

It was found that higher proportions of FBC ash with adequate water significantly increases strength and elastic modulus (Chugh et al., 1998). However, higher amounts of gob (over 50\%) adversely affects the strength of the mix. It was determined that the ratio between $\mathrm{F}$ ash and FBC ash should be kept below 0.2 to achieve high compressive strength after 28-days of curing (Chugh et al., 1998). These studies proved that the ratio between FBC ash and water content in the mix is the most important parameter for determining strength and elastic modulus. In addition, the ratio between $\mathrm{F}$ ash and FBC ash also play an important role in compressive strength for 7-day cured samples. Thus, in this study, two independent variables (F-ash/FBC ash, and FBC ash/Water) are considered to establish relationships with uniaxial compressive strength and elastic modulus for 7-day and 28-day cured samples. Similar relationships are also developed for hydraulic conductivity, durability and swelling strain of the mix.

Regression analysis provided the following relationships for 7-day compressive strength with $\mathrm{r}^{2}$ and $\mathrm{F}$ value of 0.838 and 46.77

$$
\sigma_{7}=13.2\left(\frac{F}{F B C}\right)+156.95\left(\frac{F B C}{W A T E R}\right)
$$

The coefficient of FBC/WATER passes the $t$-test with a $t$ value of 27.97, for $\alpha=0.05$. This variable has significant effect on compressive strength of 7-day cured samples. The coefficient, F/FBC also passes the t-test for $\alpha=0.05$. F/FBC also contributes to the 7day compressive strength. Thus, it is a valid statistical model. Figure 7 shows the linear relationship and $95 \%$ confidence intervals for 7-day compressive strength with FBC/WATER. This figure also shows that 7-day compressive strength of samples similar to the field mix provides a good match with the predictive model. 


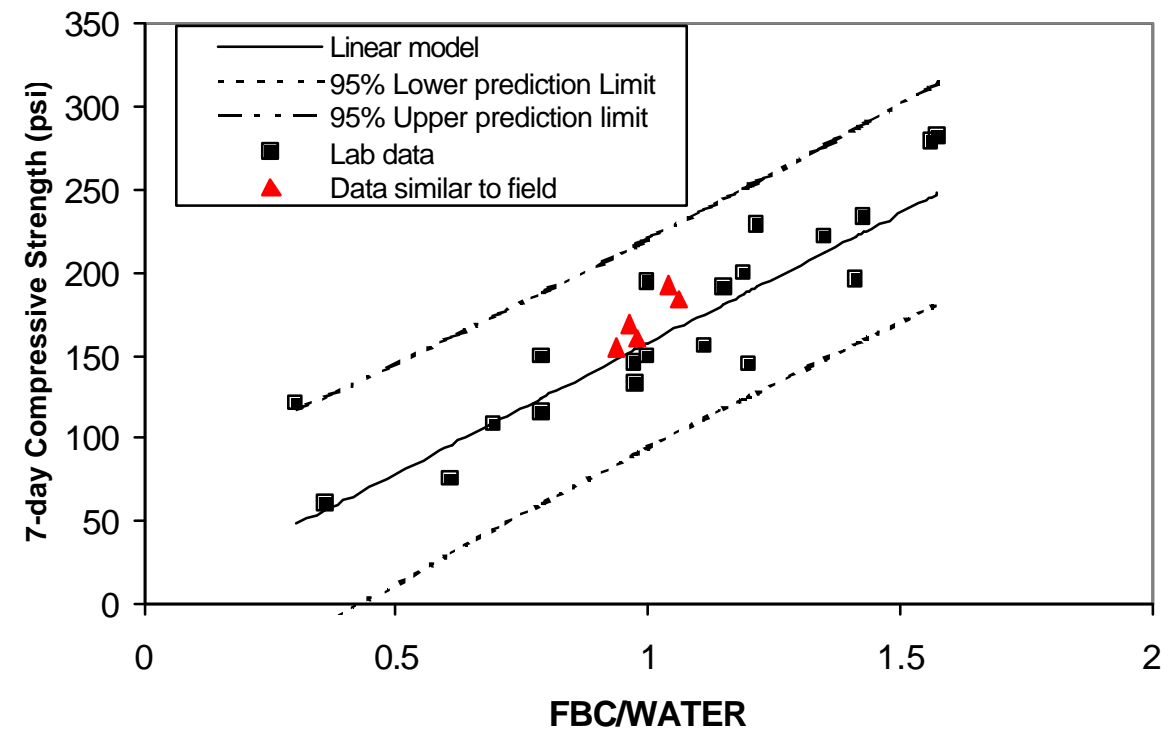

Figure 7. Relationship between 7-day compressive strength and FBC/WATER ratio

The variable, FBC/WATER is significant because FBC ash is cementitious and contains free lime $(\mathrm{CaO})$. In the presence of water, FBC helps to cement F-ash and gob together. However, excessive amounts of water and gob have an adverse affect on the compressive strength as well as on the elastic modulus. Larger particle size gob will also reduce compressive strength due to uneven gob size distribution in the sample.

The relationship between the 7-day elastic modulus with the above mentioned independent variables reveals that $\mathrm{F} / \mathrm{FBC}$ is statistically insignificant and does not pass the t-test with $95 \%$ confidence level. As a result, the relationship with 7-day elastic modulus is given as follows:

$$
E_{7}=13723\left(\frac{F B C}{W A T E R}\right)
$$

This relationship has the $\mathrm{r}^{2}$ and $\mathrm{F}$ value of 0.772 and 64.44, respecitvely. Thus, $\mathrm{E}$ is significantly dependent on FBC/WATER. Figure 8 shows the linear relationship and 95\% confidence intervals for the 7-day elastic modulus and the variable FBC/WATER. This figure also shows a good match for the 7-day elastic modulus with data similar to the field mix. 


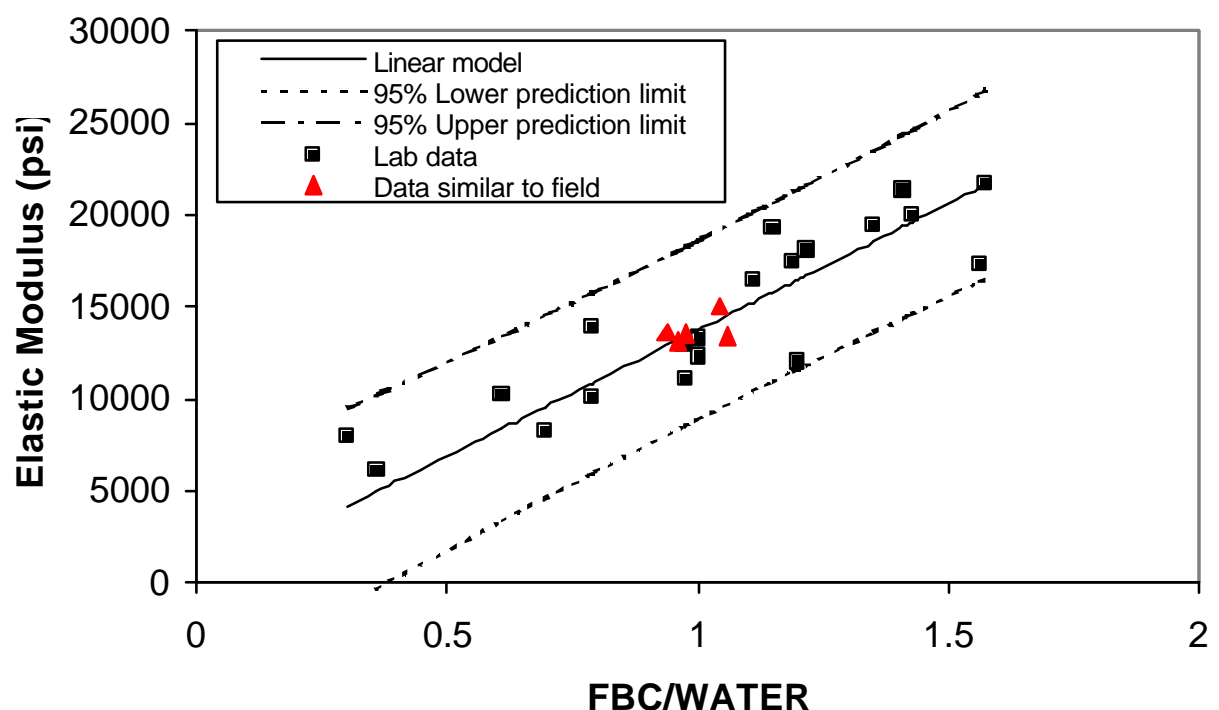

Figure 8. Relationship between 7-day elastic modulus and FBC/WATER

Analysis was also extended to estimate the 28-day strength and elastic modulus using linear models for both variables. F/FBC has insignificant effect and FBC/WATER is the dominant parameter for the 28-day strength and elastic modulus. The following two equations are obtained from regression analysis:

$$
\begin{aligned}
\sigma_{28} & =330.10\left(\frac{F B C}{\text { WATER }}\right) \\
E_{28} & =20442\left(\frac{F B C}{\text { WATER }}\right)
\end{aligned}
$$

These two models have $\mathrm{r}^{2}$ and $\mathrm{F}$ values of 0.761 and 60.42 and 0.506 and 19.57, respectively. Both relationships are statistically significant and FBC/WATER does affect 28-day compressive strength and elastic modulus. Figures 9 and 10 show the linear model with $95 \%$ prediction intervals. These figures also show that the data for samples similar to the field mix lie close to the linear model. 


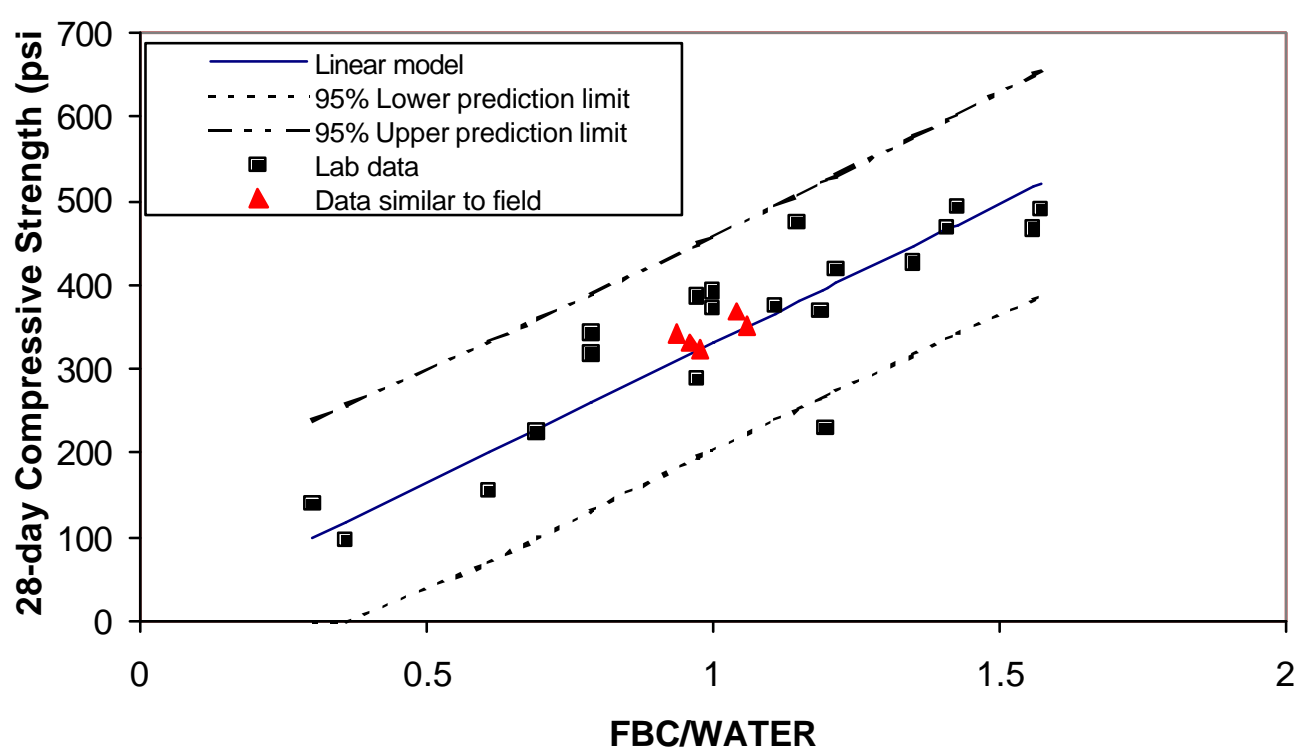

Figure 9. Relationship between 28-day compressive strength and FBC/WATER ratio.

Final Mixes Selection: Freeman United Coal Company and the Industry steering committee selected four (4) final mixes for further consideration. Compositions of the final four mixes are given in Table 3. Engineering properties of final mixes are given in Table 4. In the steering committee meeting on April 15, 1999, it was decided that Mix 25 and Mix 18 only would be considered for underground backfilling. For final underground demonstration, Mix 18 only was selected. The flow characteristics of this mix were excellent even though it contains $40 \%$ crushed gob. This mix ("field mix") was slightly modified for field demonstration based on resource availability of different mix constituents. This mix has 33\% gob, 53\% FBC ash, 14\% F-ash, and 50\% water.

Table 3. Proportions of raw ingredients of four final mixes.

\begin{tabular}{|l|l|l|l|l|l|}
\hline Components & Mix 1 & Mix 25 & Mix 18 & Mix 21 & Mix 26 \\
\hline Gob, \% & 33 & 25 & 40 & 45 & 45 \\
\hline FBC fly ash, \% & $53 \%$ & 62.5 & 50 & 55 & 46 \\
\hline F-type fly ash, \% & $14 \%$ & 12.5 & 10 & 0 & 9 \\
\hline
\end{tabular}




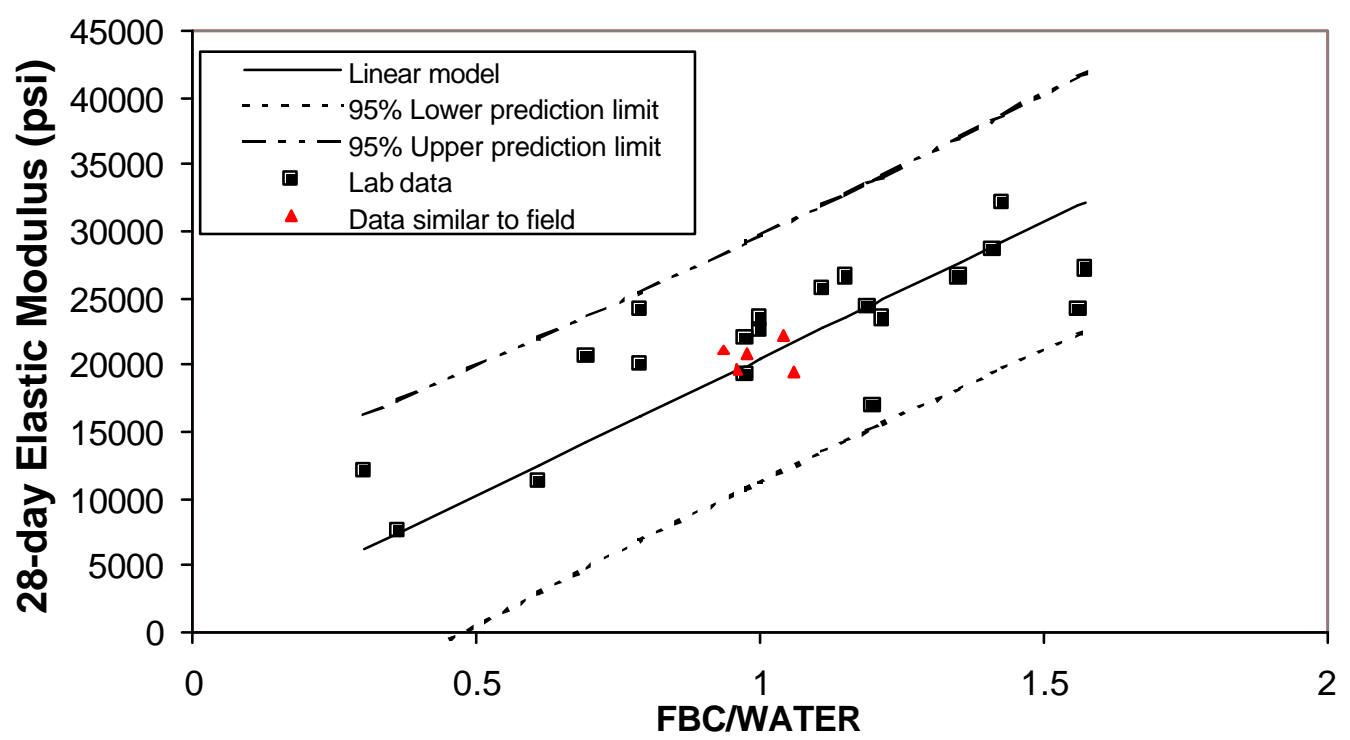

Figure 10. Relationship between 28-day elastic modulus and FBC/WATER

Development of Additional Mixes Similar to the Field Mix: In the laboratory, five mixes were prepared by slightly varying the field mix as shown in Table 5. In this table, mix 1 refers to the field mix compositions. Moisture or water was added to achieve a slump height of 11 inches with a minimal bleed of about 3-4\%. For each mix, three samples were prepared and tested for their compressive strength and elastic modulus after 7-day and 28-day curing. Hydraulic conductivity, swelling strain and slake durability tests were also performed for each sample. Analysis based on these samples provides a better estimation of engineering properties of paste backfill injected in Crown III mine. Compressive strength and elastic modulus data of these samples are also used to verify the linear regression models developed earlier.

Table 4. Engineering properties of the final mixes.

\begin{tabular}{|l|l|l|l|l|}
\hline Property & Mix 25 & Mix 18 & Mix 21 & Mix 26 \\
\hline 7-Day strength, psi & 479 & 243 & 168 & 430 \\
\hline 28-Day strength, psi & 523 & 523 & 492 & 579 \\
\hline 7-day elastic modulus, psi & 22,407 & 20,000 & 19,433 & 26,452 \\
\hline 28-day elastic modulus, psi & 36,822 & 27,000 & 37,156 & 33,750 \\
\hline Water needed for 9-inch slump, \% & 40 & 36 & 39 & 40 \\
\hline Bleed for 9-inch slump, \% & 1.1 & 1.6 & 1.6 & 1.6 \\
\hline CCE, \% & 45 & 44 & 41 & 36
\end{tabular}


Table 5. Proportions of additional mixes similar to the field mix.

\begin{tabular}{|l|l|l|l|l|}
\hline Mix & Gob & FBC-Ash & F-Ash & Moisture \\
\hline $1 *$ & 0.33 & 0.53 & 0.14 & 0.5 \\
\hline 2 & 0.35 & 0.5 & 0.15 & 0.48 \\
\hline 3 & 0.4 & 0.45 & 0.15 & 0.46 \\
\hline 4 & 0.4 & 0.5 & 0.1 & 0.52 \\
\hline 5 & 0.45 & 0.45 & 0.1 & 0.48 \\
\hline
\end{tabular}

*Composition of field mix

\section{- Construction of Mixing Plant at Crown III Mine}

The concrete mixing plant, used for underground backfilling studies at Pawnee mine, was dismantled and moved to Crown III mine. The mixing plant was set up at Crown III mine in March 1999. Electrical wiring and water pipe connections were finished by June 1999. Figure 11A-B shows the mixing plant and its various components. Several tests were performed to check the conditions of its various components. One of the important factors was to obtain optimum speeds of the three belts, which carry FBC ash, gob and Fash to the main belt. Table 6 shows the characteristics of these belts. Using the specified speeds, final field mix of the $53 \% \mathrm{FBC}, 33 \%$ gob and $14 \% \mathrm{~F}$-ash was obtained. At the pug mill, water was added to mix solids and then pump it into a pit below. FBC and Fash belt discharged materials to the main belt through a chute. Gob was discharged directly onto the main belt. FBC ash fugitive dust was controlled using water sprays at four different locations around the chute.

Table 6. Characteristics of conveyor belts.

\begin{tabular}{|l|l|l|l|l|l|}
\hline Belt & $\begin{array}{l}\text { Length } \\
\text { (ft) }\end{array}$ & $\begin{array}{l}\text { Speed } \\
\text { (ft/min) }\end{array}$ & $\begin{array}{l}\text { Capacity } \\
\text { (ton/hour) }\end{array}$ & $\begin{array}{l}\text { Weight } \\
\text { (lb/ft) }\end{array}$ & \% Weight \\
\hline Gob & 65 & 66.7 & 30.02 & 15.00 & 32.99 \\
FBC & 38 & 23.1 & 48.51 & 70.00 & 53.32 \\
F-ash & 40 & 17.8 & 12.46 & 23.33 & 13.69 \\
Main & 120 & 66.7 & 90.99 & 108.33 & 100 \\
\hline
\end{tabular}

The peak mixing rate of this plant was designed not to exceed 100 ton/hour of solid and 40 ton/hour of water. This mix provides about 11 inch of slump height. The plant was operated with a water addition rate of 138-152 gallons per minute to obtain a mix of at least 11-inch slump. It was difficult to maintain a constant feed rate of solids into the pug mill. Specifically, the composition of the three components varied slightly depending on the amount of material in the respective hoppers. Moisture content in these components also changed based on weather conditions.

Gob was crushed using a jaw crusher to provide maximum 0.75 inch size material. The size distribution data for gob is given in Figure 6. The crusher was located near the mixing plant. A front-end-loader carried the crushed gob and dumped it into the gob 
hopper of the mixing plant. F-ash and FBC fly ash were supplied at the plant site and front-end-loader dumped them into the respective hoppers.

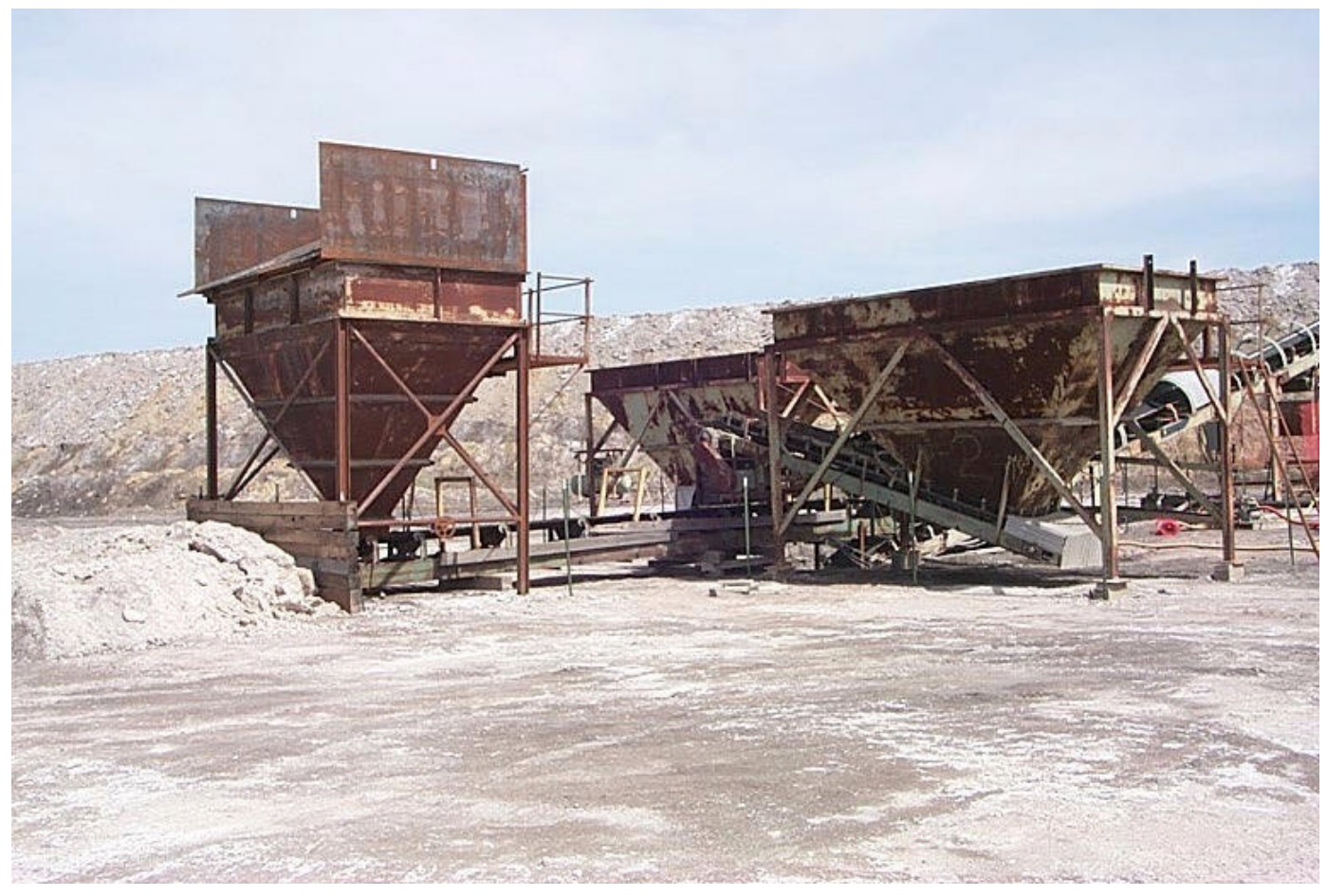

Figure 11A. A view of the mixing plant.

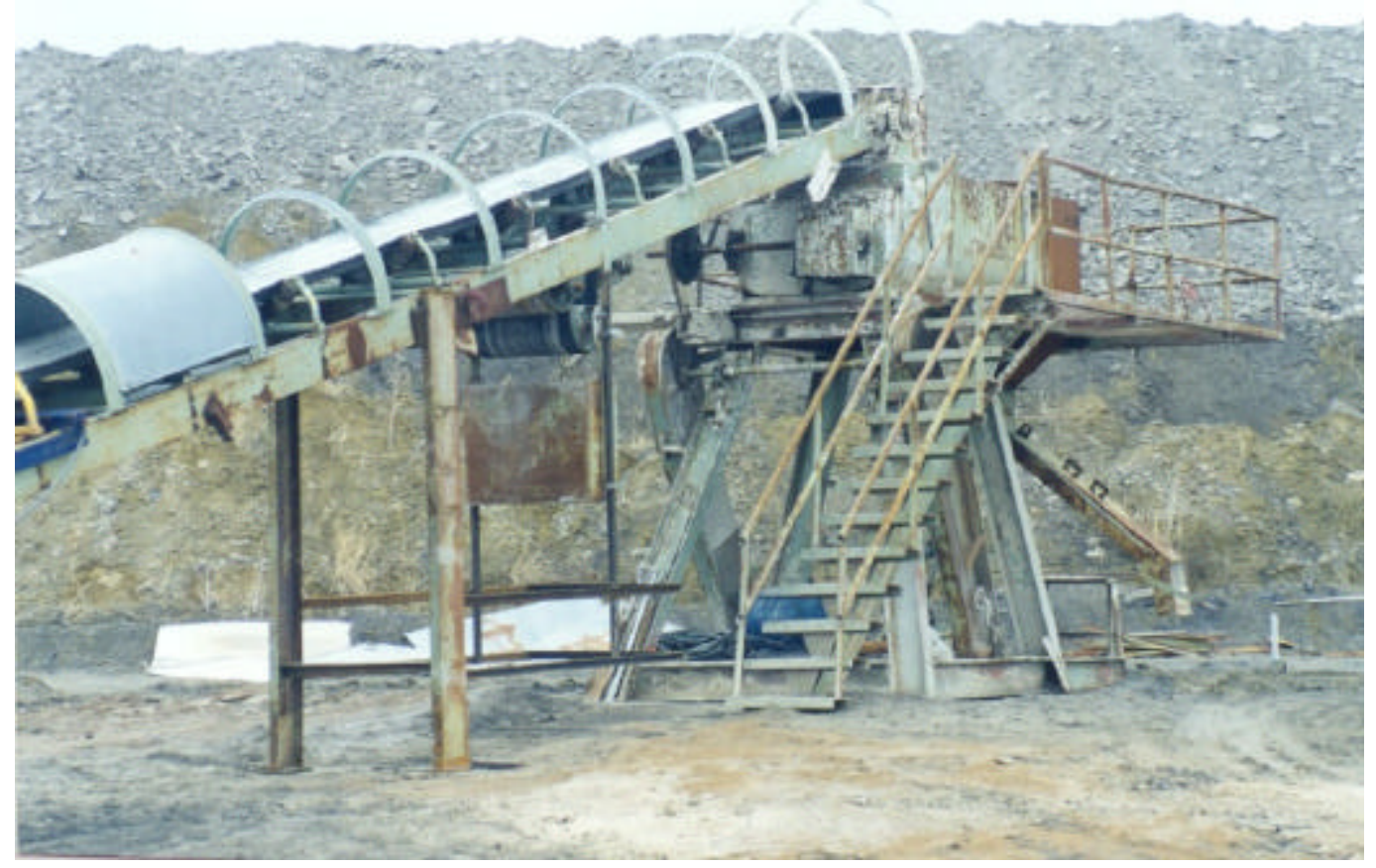

Figure 11B. Another view of the mixing plant. 


\section{- Surface Demonstration of Field Mix Flow Characteristics}

A trench was dug with two crosscuts on the surface. Figures 12A and Figure 12B show the schematics and a picture of this trench, respectively. The trench was about $100 \mathrm{ft}$ long, $9 \mathrm{ft}$ wide and 6-10 ft deep. On August 9, 1999, the mix with 40\% gob (Mix 18) was pumped into this trench to observe the flow behavior. Representatives from IDCCA, Freeman United, ICCI, SIUC, Ameren CIPS, Old Ben Coal, Peabody Coal, and IDMM were present during this demonstration. The mix flowed in all directions after discharge with little separation of water and solid components. It was also found that the mix flowed under water without much separation.

\section{- Borehole Camera Survey}

Two boreholes were drilled and cased for backfill injection process. The borehole diameter was 8.5 inch to 9.0 inch with schedule 40, 6-inch diameter steel casing. The annular space between the borehole and casing was filled with cement grout. The steel casing was within 10-ft of the top of the coal seam. Through the steel casing 5.875 inch diameter hole was drilled to intercept the coal seam.

On July 7, 1999, a borehole camera was lowered by OSM staff and found that both the holes were open for backfilling. Representatives from IDDCA, SIUC, Freeman United, and OSM were present during this task. Figure 13 shows the lowering of this camera in the second (alternate) borehole. In the first (primary) hole, the camera was lowered to the mine floor level and the distances of coal pillars from the borehole were measured. There was a roof fall in the second (alternate) borehole. However, from the camera survey, it was found that the entries in three directions were still open.

\section{- Field Demonstration of Underground Backfilling Using The Mixing Plant- Phase I (First Borehole)}

On August 11, 1999, field demonstration of the underground backfilling operation began though the first (primary) hole. For quality control, several tests were performed every day to check the slump height, strength and modulus of elasticity. Ho urly and shift rates of backfill material (solid and water) were recorded from the belt scale and water meter. An hour-meter was installed to estimate net operation time in every shift. This operation was conducted in two eight-hour shifts every day. Day shift began from 6:00 a.m. to 3:00 p.m. and evening shift started at 3:00 p.m. and ended at 10:00 p.m. No work was performed on Saturdays and Sundays. In the evening shifts, regular maintenance of belts, motors, etc. were scheduled.

In every shift, four cylindrical samples were prepared (three samples $3 \times 6$ inches, and one $6 \times 12$ inches) for strength tests. Slump height was measured every hour to check the water content and flow behavior of the mix. The mix was backfilled underground by dumping it through the borehole under gravity. It was estimated that about 325 to $350 \mathrm{ft}$ of vertical head would be sufficient to make this mix flow underground. 


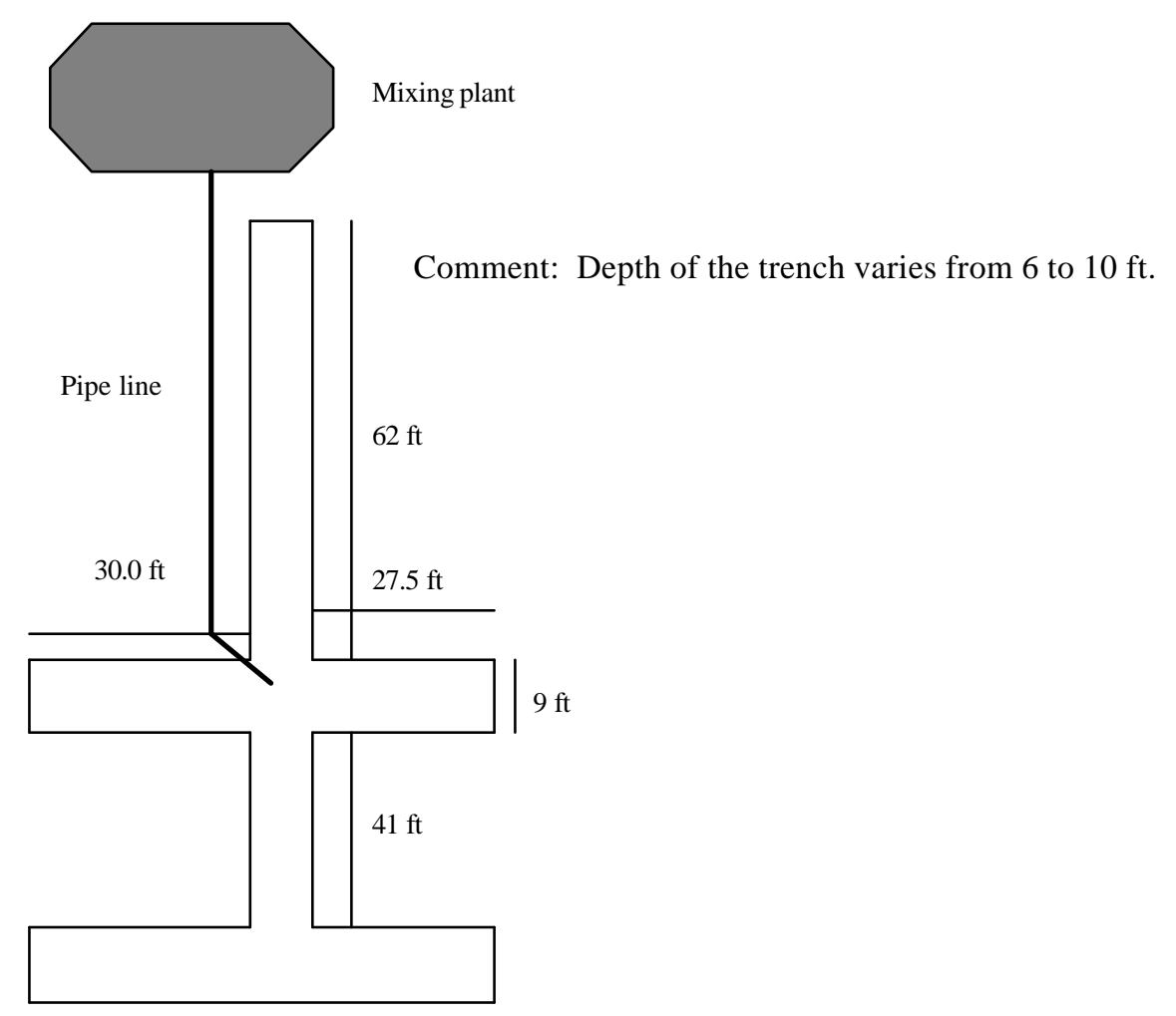

Figure 12A. Schematics of the surface trench.

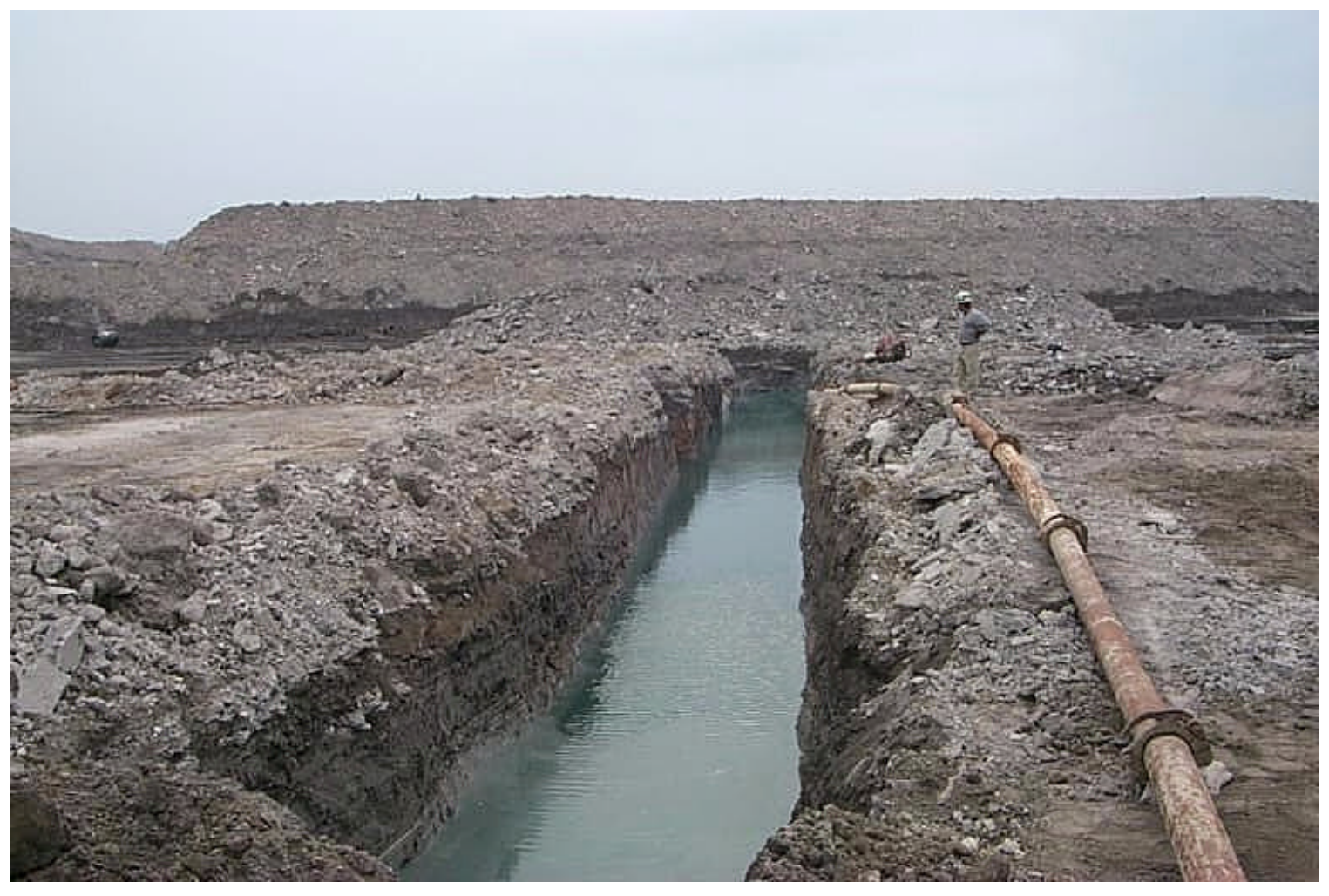

Figure 12B. Picture of the surface trench. 


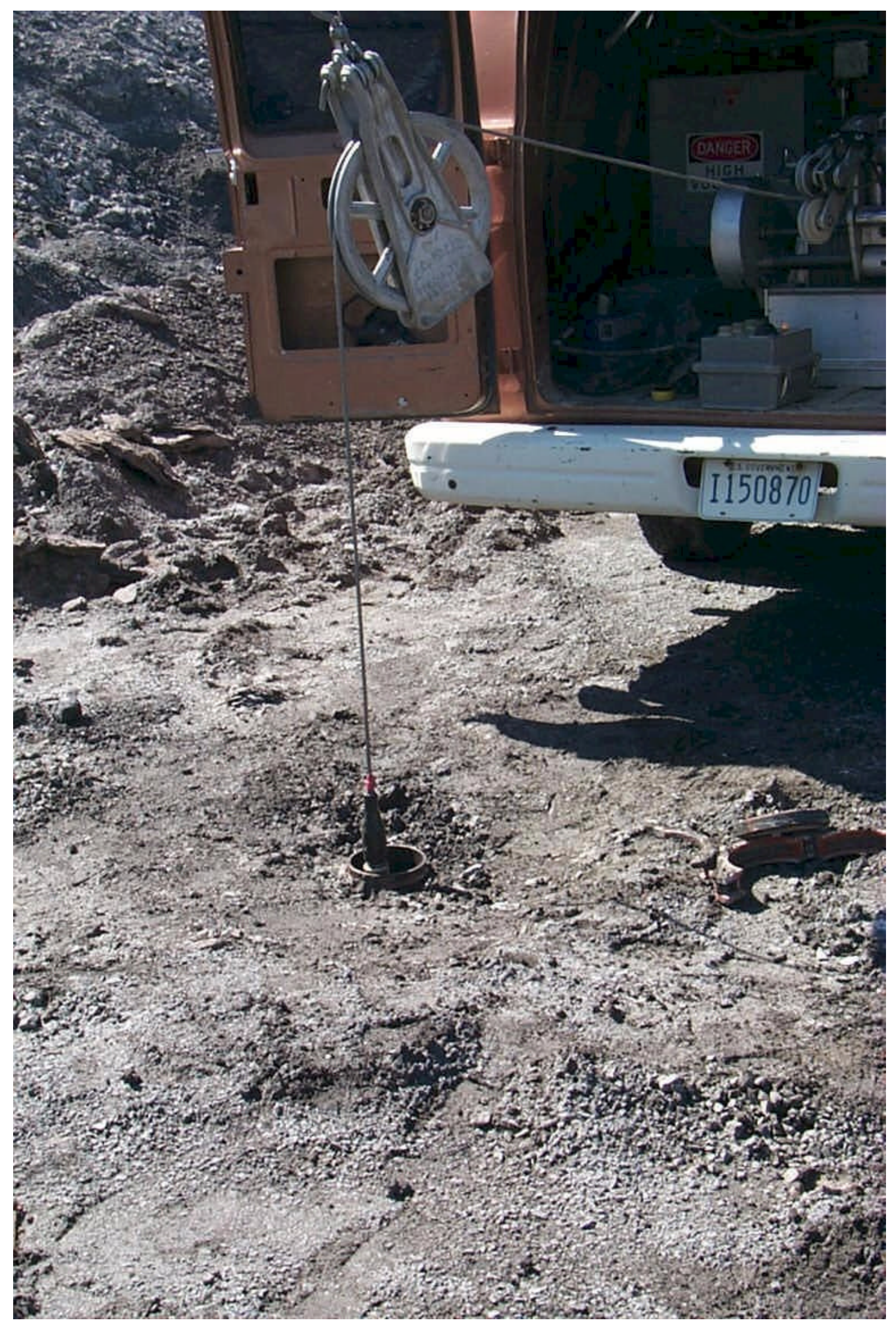

Figure 13. Borehole camera survey. 
After the primary hole choked on September 8, 1999, the backfilling operation was halted for several days. MSHA examiners suggested sealing off the panel underground before resuming any further operation. The panel was sealed by early October and backfilling operation was resumed through the second hole on October 13, 1999. A concrete pump was used to pump mix over $200 \mathrm{ft}$ from the mixing plant to the second hole. Since the capacity of the pump is lower than that of the mixing plant, mixing rate of the plant was reduced to minimize the pump overflow. However, after two days of operation the pump broke down. The pump was repaired within a week. Operation began again on October 22, 1999 and finally it was stopped the following day because this area had to be prepared for CCBs management during winter. During fall 1999, Phase I of field demonstration was completed.

Figures 14 shows the daily and hourly rates of backfilling operation through the primary borehole. The daily average backfilling rate was 627 tons (452 ton of solid and 175 ton of water). The average water to solids ratio was about $40 \%$. With this ratio, 11-inch slump height was achieved. The average hourly rate of mix was 117.1 tons/hour $(83.5$ ton/hour of solid and 33.6 ton/hour of water). About 8159 tons (5873 ton of solid and 2286 ton of water) of mix was backfilled underground though the primary borehole until the hole choked. Net operational time was 68.4 hours with an average of 3 hours per shift.

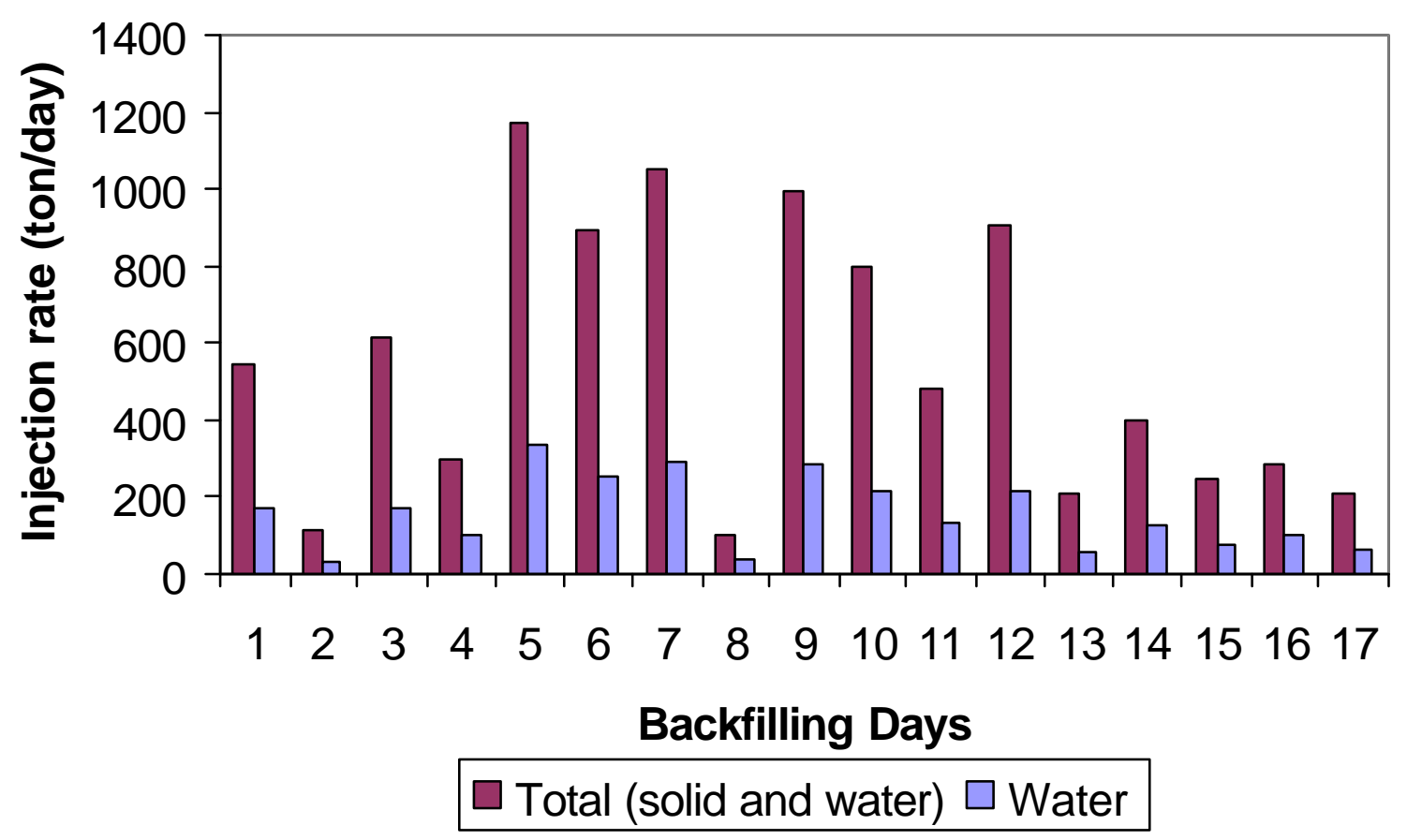

Figure 14. Daily backfilling rate through primary borehole (Phase I).

Only four days of operation was possible through the second borehole. Within these four days, 1134 ton (773 ton solids and 361 ton water) were placed underground in 14.4 net hours of operation (Figure 15). The average hourly rate was 79 ton/hour of solid and 
water (54 ton/h solid and 25 ton/h water). These rates are lower than those in the primary hole due to the size restriction of the concrete pump. In this case, water to powder ratio is 0.4 .

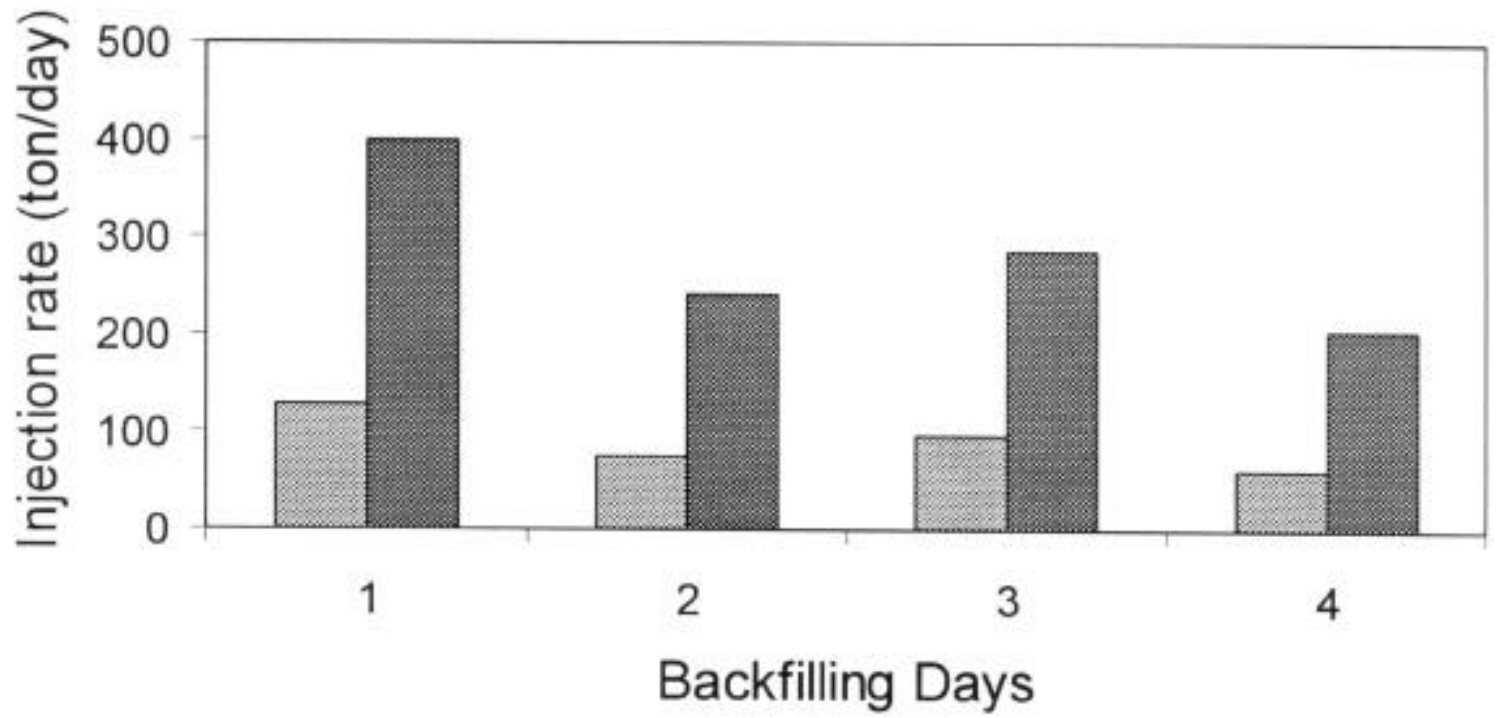

\section{Water Total (Solids and Water)}

Figure 15. Daily backfilling rate through the secondary borehole (Phase I).

Altogether using both holes, about 9293 ton of solid and water mix were injected underground. The overall water to powder ratio was about 0.40 .

FBC fly ash dust control and frequent plant breakdowns were some of the problems encountered in this operation. Due to these problems, the efficiency of the backfilling operation was relatively low. However, better than expected flow characteristics were achieved underground. It was concluded that operating this plant continuously around the clock would have resulted in much higher backfilling rates. However, this arrangement could not be made due to logistical problems such as manpower, equipment and material availability and high possibility of plant breakdowns. As a result, two shift operations were scheduled giving plant maintenance and gob crushing preferences on the evening shift.

\section{- Underground Backfill Flow Characteristics}

Figure 16 shows the characteristics of underground mix flow (dark shaded region) recorded on August 24, 1999. After this date no underground visits were made. Until this date, about 4770 tons of mix (solid and water) were backfilled underground. It was observed that the mix flowed in all four directions especially to the west and south-west. Mine entries were filled 30-feet from the borehole in all directions to within $1 \mathrm{ft}$ of the roof. 


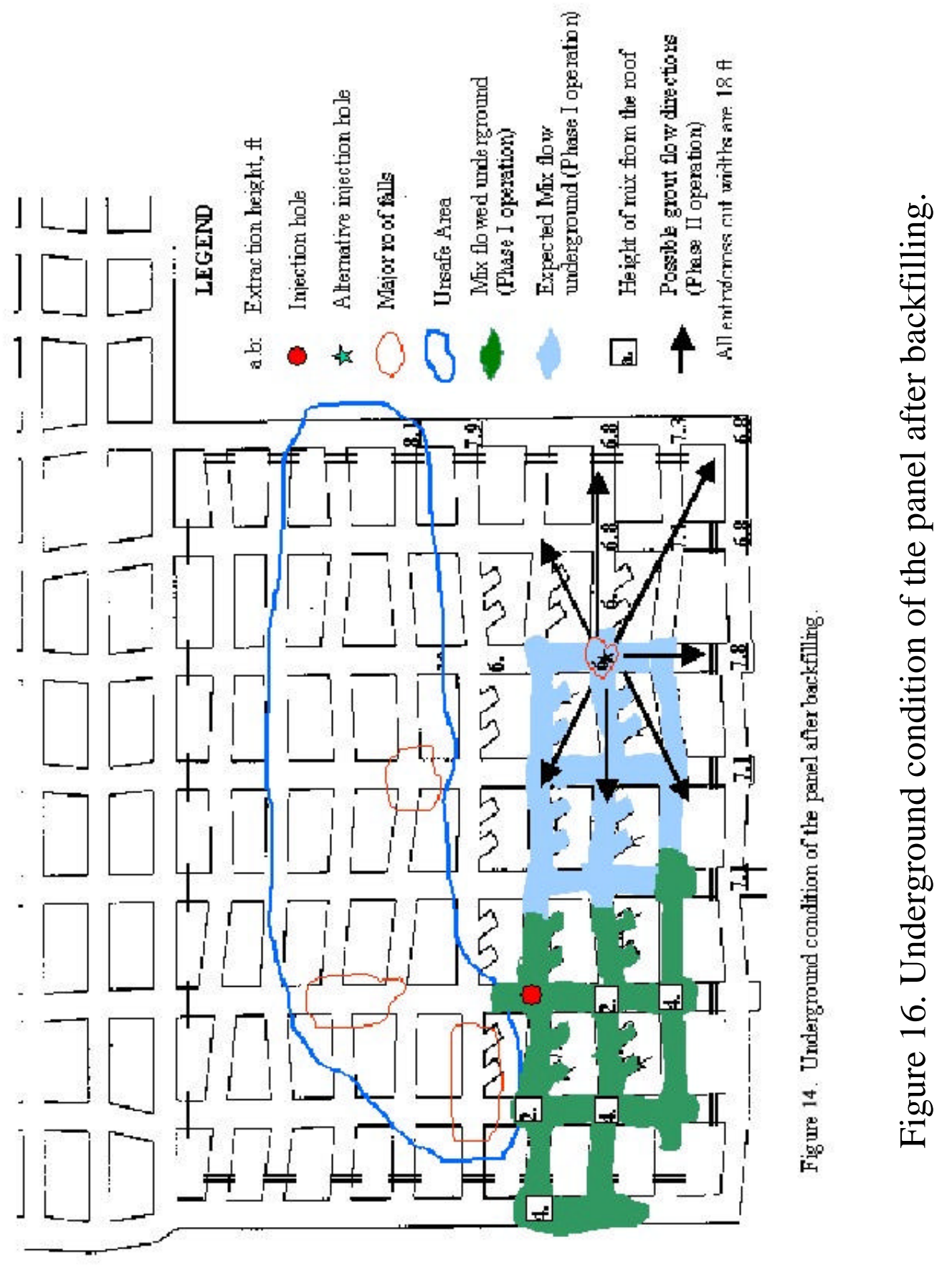

The backfill gradient was as low as 2 degrees and the mix had flowed a maximum distance of $120 \mathrm{ft}$. It was also observed that the mix flowed uniformly as a sheet-typeflow and did not form any channels. There was hardly any separation between solids and water. High volume of gob in the mix did not impede underground flow behavior. Moreover, the strength of the mix after twenty-four hours of curing was sufficient to 
sustain the weight of human beings. Underground observers had no problem walking over the thick sheet of mix.

After August 24, 1999 another 3,389 ton and 1,134 ton of backfill were dumped through the primary borehole and the second borehole, respectively. Mining staff visiting underground indicated that the backfill material flowed at least $300 \mathrm{ft}$.

\section{- Field Demonstration of Underground Backfilling Using A High-Speed Auger Mixer-Phase II (Second Borehole)}

After the Phase I operation was completed, the surface area, where the mixing plant was located, was filled with coal combustion by-products. However, the second hole was kept open during this process. The borehole casing was extended vertically upward during the filling process. Phase II of the field demonstration process began on September 27, 2000. In this operation, a high-speed auger with one hopper and conveyor belt system was used to mix solids with water. The following sections describe the mixing plant and backfill injection procedure for Phase II operation.

Borehole Camera Survey: On September 18, 2000 a borehole camera was lowered through the second (alternate) hole to observe the underground conditions at the intersection. This demonstration was performed with the cooperation of OSM as before. It was found that entries in two directions (south and west) were open while the entry towards the east may be closed. The earlier roof fall completely blocked the entry toward north. However, no new roof falls were observed during this survey.

High-Speed Auger Mixing Plant: In this operation, a high-speed 12 inch diameter auger mixer was used to mix solids and water. This mixer is powered by a hydraulic engine operating at $350 \mathrm{rpm}$. A hopper was set up to deliver premixed solids to the auger mixer using a variable speed conveyor belt. Water was added into the mixer. Figure 17 shows the auger mixer, the borehole and part of the conveyor belt carrying solids into the mixer.

Experiments were conducted to adjust the feed rate of solids and water so that the auger would run without clogging. It was found that the amount of water injected into the auger determines the amount of solids intake. Table 7 shows adjustment of the amount of water and solids to achieve the desired mix.

During this operation, 3x6 inch cylindrical samples were prepared every day for testing compressive strength and elastic modulus. These samples were brought to SIUC laboratory for testing. Samples will be tested after 7 day, 28 day and 90 day curing cycles. 


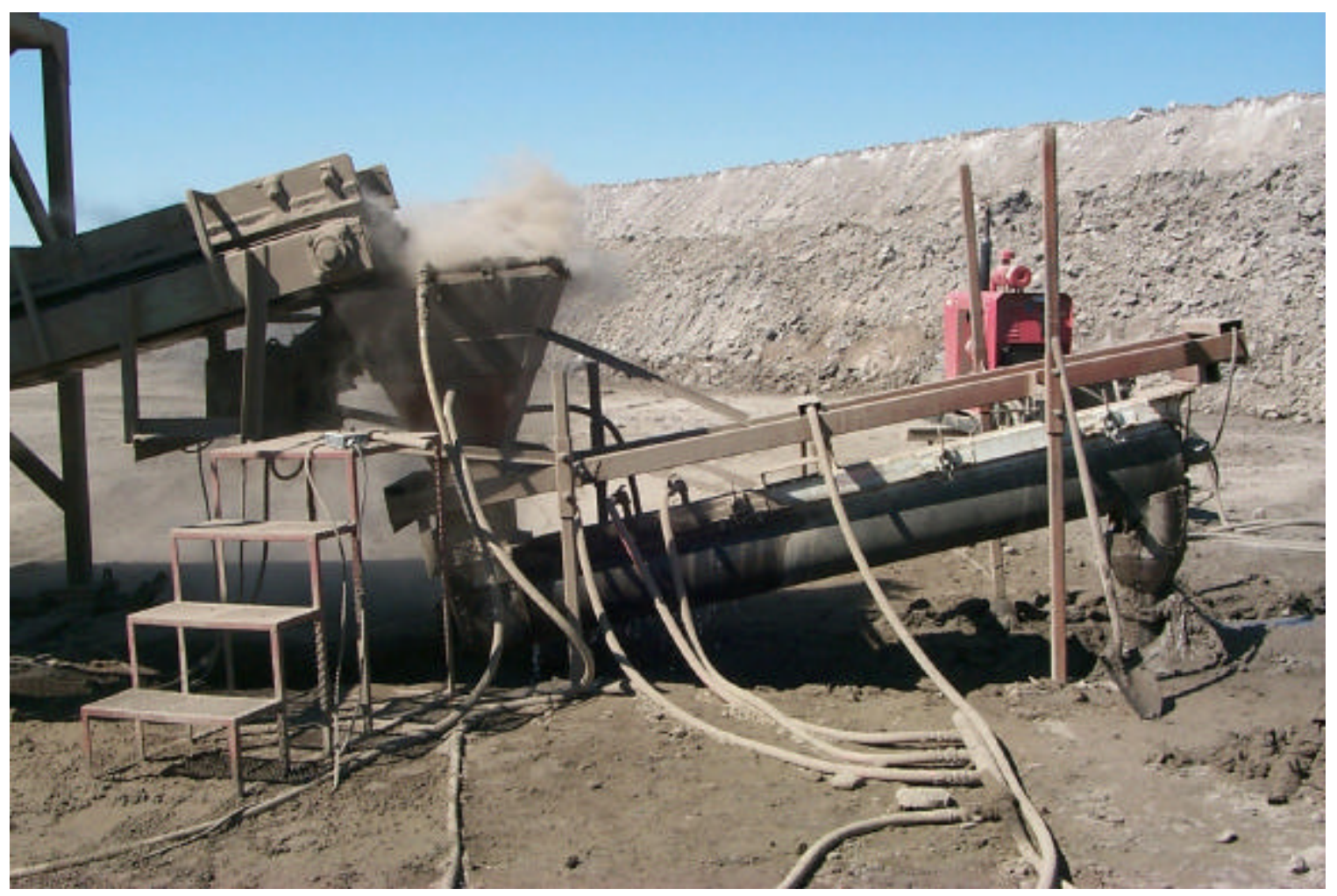

Figure 17. Backfilling operation using auger mixer.

Table 7: Adjusting the speed of conveyor belt based on water feed rate.

\begin{tabular}{|l|c|c|c|c|}
\hline $\begin{array}{c}\text { Adjustment } \\
\text { Date }\end{array}$ & $\begin{array}{c}\text { Conveyor Belt } \\
\text { Length (ft) }\end{array}$ & $\begin{array}{c}\text { Conveyor Belt } \\
\text { Speed (ft/min) }\end{array}$ & $\begin{array}{c}\text { Capacity } \\
\text { (ton/hour) }\end{array}$ & $\begin{array}{c}\text { Water } \\
\text { (gal/min) }\end{array}$ \\
\hline $9 / 27 / 00$ & 40 & 17.78 & 18.67 & 35 \\
$10 / 3 / 00$ & 40 & 36.92 & 83.07 & 75 \\
$10 / 16 / 00$ & 40 & 42.86 & 109.29 & 85 \\
$10 / 30 / 00$ & 40 & 60.00 & 64.80 & 100 \\
\hline
\end{tabular}

Underground Backfilling Operation Through Second Borehole: Backfilling operation began on September 27, 2000. As of October 30, 2000, about 6,000 tons of grout (solids 4031 tons, water 1886 tons) were injected underground with a water to powder ratio of 0.47. Figure 18 shows the daily injection rate of this operation. The average daily injection rate was 348 tons of grout (237 tons of solids and 110 tons of water). The net operational time for this operation was estimated to be about 106 hours.

This phase of operation was conducted in one long shift (10 hours) per day. There were a few days that backfilling could not be done due to rain. At one time, the conveyor belt broke down and three working days were lost. Other than these problems, backfill operation went satisfactorily. 


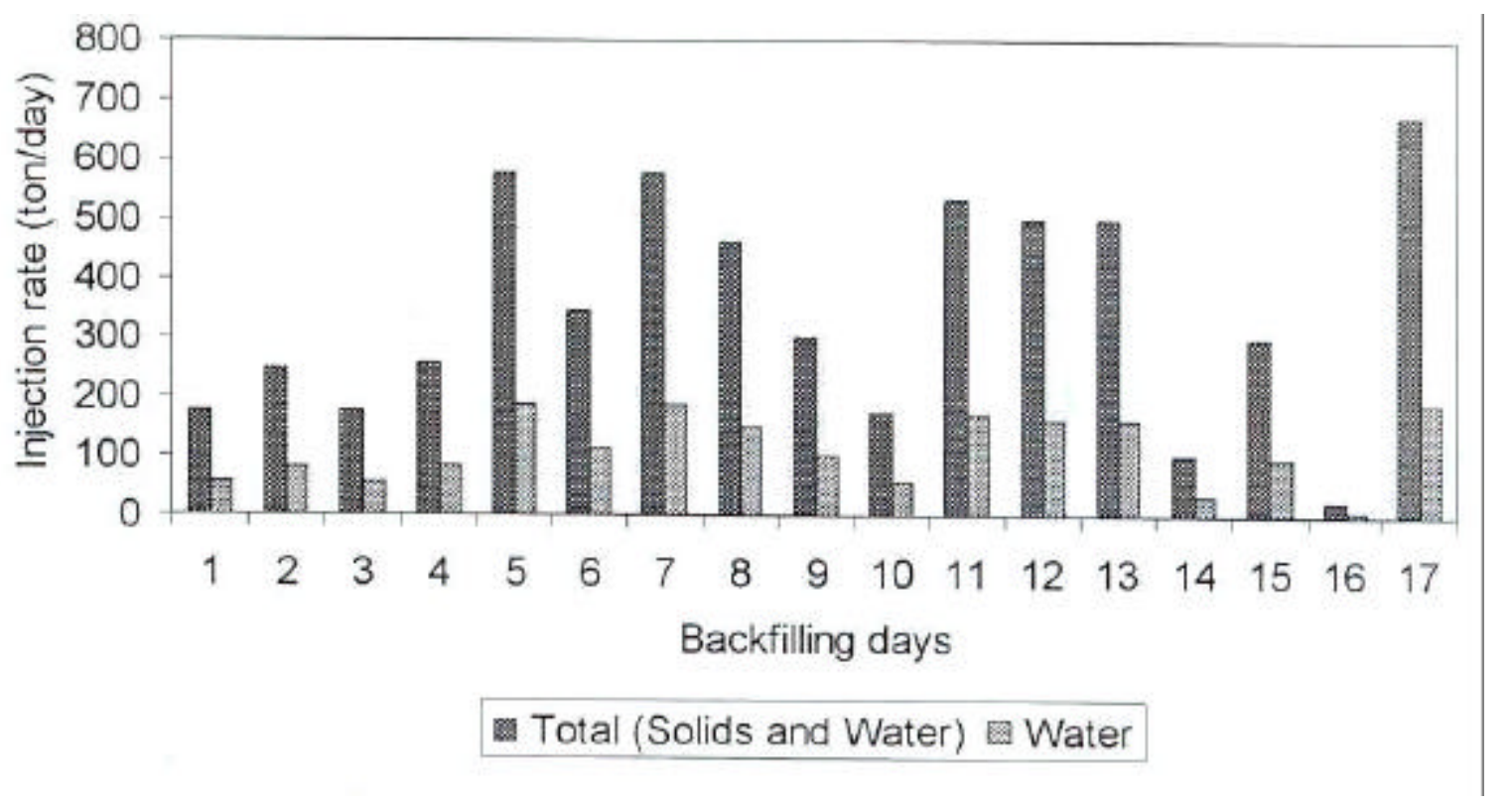

Figure 18. Daily backfilling rate using secondary borehole (Phase II).

The FBC fly ash fugitive dust problem was reduced by using a closed auger mixer instead of conveyor belts and a pug mill as in the case of Phase I backfilling operation. In addition, a water sprinkler was placed where the conveyor belt empties solids to a bin of the auger mixer for controlling dust. The number of personnel required for backfilling operation was reduced to one since only one conveyor belt was needed instead of four. This plant has only two pieces of moving equipment: a conveyor belt and an auger mixer. Thus, chances of equipment breakdown are also reduced significantly from Phase I operation. The mining company strongly favored high-speed auger mixing technology over the concrete mixing plant set up.

Backfill Flow Characteristics: Since the backfilling panel was permanently sealed after Phase I demonstration, no visit could be made underground to look at the extent of grout flow. It was hypothesized that the grout would flow towards the east, west and south directions where the entries were open. Since the second borehole was not choked after injecting about 6,000 tons or 140,000 cft of grout, the grout must be flowing away from the borehole in different directions. It was estimated that the total injected grout would fill 900-1,000 ft of mine voids considering a $20 \mathrm{ft}$ wide entry and $7 \mathrm{ft}$ of opening height. Figure 18 shows the possible directions grout may have flowed underground. It is hypothesized that the grout flowed better in this case as compared to Phase I operation since the grout is composed of F and FBC ash only. There was no gob material in the mix. 


\section{- Engineering Properties of the Field Mixes Recovered During Field Demonstration}

Typical stress-strain curves of 7-day, 28-day and 90-day cured samples are shown in Figure 19. Table 8 shows the strength and elastic properties of these samples. The strength and modulus values of the 28-day cured samples are less than those of laboratory specimens due to the larger size gob particles and more water in the samples. Gob particle size above 0.5 inch was present in the field samples while in the laboratory gob particles below 0.25 inch only were considered. Due to the addition of four water sprinklers for controlling FBC ash fugitive dust the field mix contained more water than the laboratory samples. It was found that the field mix contained about $9.5 \%$ water $(21 \%$ if rain-soaked) before water was added at the pug mill. Therefore, elastic properties of larger cylindrical samples (6x12 inch) may provide close approximation of the properties of the backfill material.

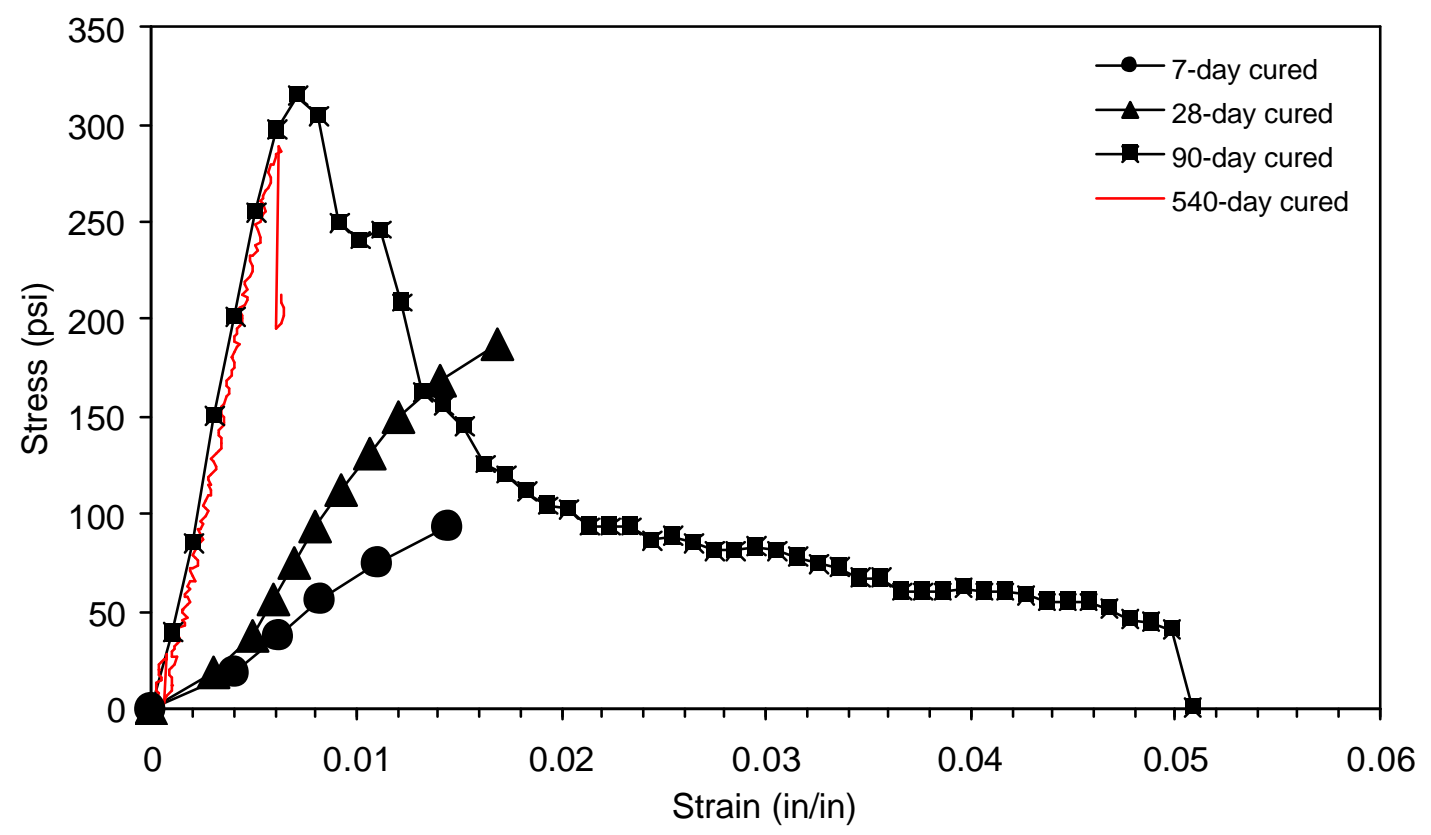

Figure 19. Stress strain relationship for field samples for different curing times.

It is observed that strength and stiffness after 90 days, and 540 days of curing are much higher than those of 7-day and 28-day curing. Table 10 shows the strength and modulus of field samples after 90-days curing and 540-days of curing. The final strength and elastic modulus of injected backfill may be close to 90-day cured samples, because the sample may not be able to dry out due to high humidity.

Field slump values suggest that for the entire backfilling operation a slump value of 11 or above was used for the backfill. The composition of the mix was kept close to the "wet" side because it was backfilled under the action of gravity. Bleed tests of this mix show 
that it was under $4 \%$ while backfilling through the primary hole and over $10 \%$ while backfilling through the second hole. More water was added in the latter case to ease the pumping of the mix from the mixing plant to the second borehole. The bleed test was also performed in the laboratory using Fash, FBC and gob collected from Crown III mine. It was found that for the same slump size the bleed is higher in the samples made from the field components (Figure 20). This is attributed to higher amounts of larger size gob particles (more that 0.25 inch) in field samples than laboratory samples and moisture content in F-ash were also higher compared to laboratory samples.

Table 8. Engineering properties of field samples.

\begin{tabular}{|c|c|c|}
\hline Curing Days & Strength (psi) & Elastic Modulus (psi) \\
\hline 7 & 103 & 6,750 \\
\hline 14 & 112 & 9,218 \\
\hline 28 & 177 & 11,929 \\
\hline 90 & 340 & 40,278 \\
\hline 540 & 559 & 85,958 \\
\hline
\end{tabular}

Table 9. Compressive strength of 90-day cured field samples.

\begin{tabular}{|l|c|c|}
\hline Sample & Strength, psi & Elastic Modulus, psi \\
\hline 1 & 667 & 49,290 \\
\hline 2 & 266 & 17,890 \\
\hline 3 & 357 & 80,675 \\
\hline 4 & 315 & 44,242 \\
\hline 5 & 159 & 23,940 \\
\hline 6 & 279 & 26,634 \\
\hline
\end{tabular}

Slake durability, permeability, swelling, bleed, slump, leachate and strength tests were performed in the laboratory for various mixes similar to the field composition.

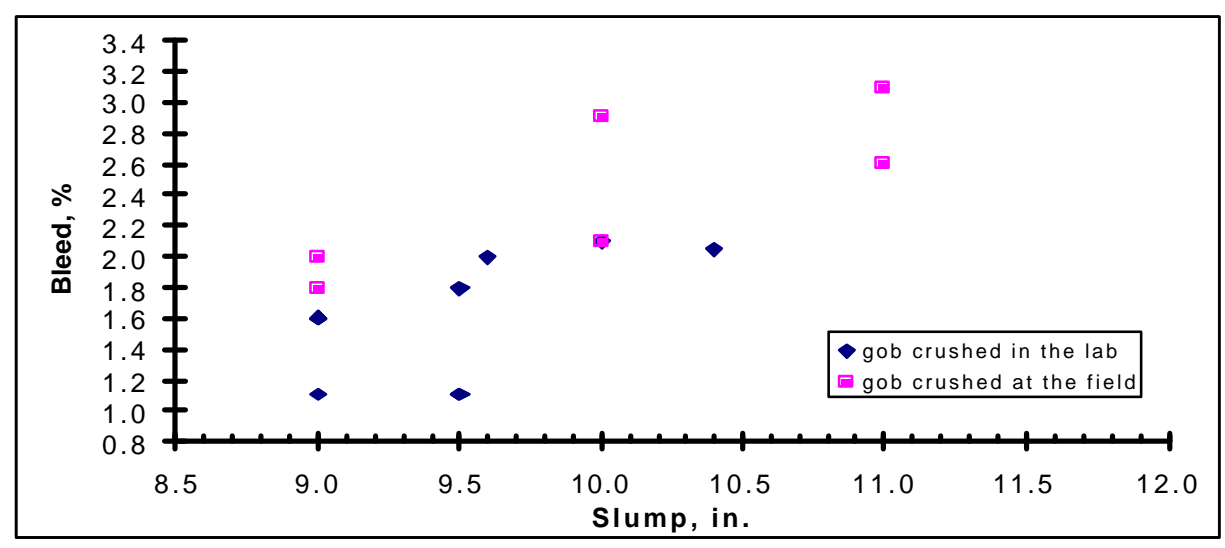

Figure 20. Comparison of slump vs. bleed for laboratory and field. 
Slake Durability: The slake durability index for samples similar to the field mix ranges from 81.59 to $88.17 \%$. Field samples show a durability index with an average of $82.0 \%$. Figure 21 shows the relationship between FBC/WATER and the durability index. As this ratio increases, durability index also increases. However, since the gob particle size is larger and water content is higher in field samples, the slake durability index is lower than that of laboratory samples. If the mine is flooded, the injected grout will not disintegrate readily based on the slake durability data above.

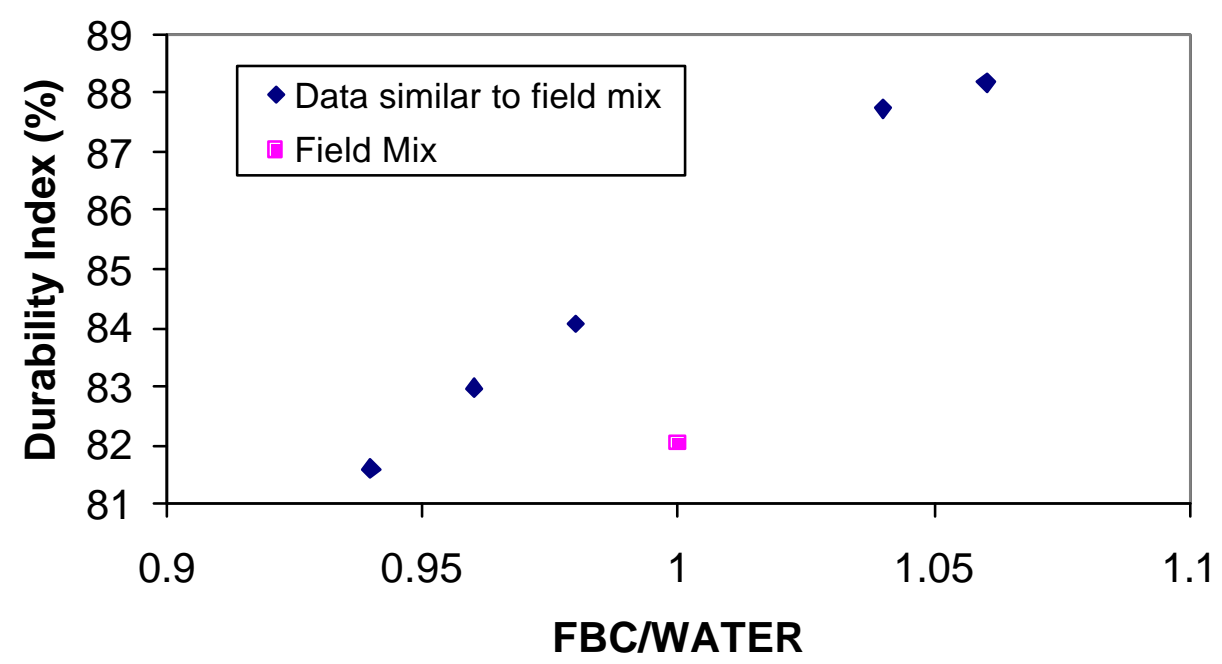

Figure 21. Variation in slake durability index with FBC/WATER ratio.

Swelling Strain: Swelling strain does not increase significantly with FBC/WATER ratio as shown in Figure 22. For the samples similar to the field mix, swelling strain ranges from 8.55 to $14.64 \%$ and the average swelling strain for the field samples is $7.4 \%$. Swelling strain is lower in the field samples due to higher water content as explained earlier. FBC ash is completely hydrated in the field samples due to excess water and thus the sample does not swell as much as the laboratory samples. That means that the injected grout underground will have a maximum swelling strain of less than $10 \%$ if it is completely saturated with water.

Permeability or Hydraulic Conductivity: Laboratory tests show that hydraulic conductivity of the samples similar to the field mix increase nominally with the FBC/WATER ratio as shown in Figure 23. Since the particle shape of FBC ash is platelike, the compaction index is high and thus porosity is low. However, higher gob and Fash content in the mix will increase the hydraulic conductivity and thus may not be suitable for an application where permeability is a major issue. In Crown III mine, the floor is composed of a weak claystone layer and it is weak in the presence of water. Injected grout underground contains about 53\% of FBC ash and is not a good conductor of water. Thus, hydraulic conductivity of the mix is low. From this figure it is estimated that if the mine is wet (flooded) then the injected grout will transmit water into the mine floor at a rate of 0.01-0.06 inch/day. 


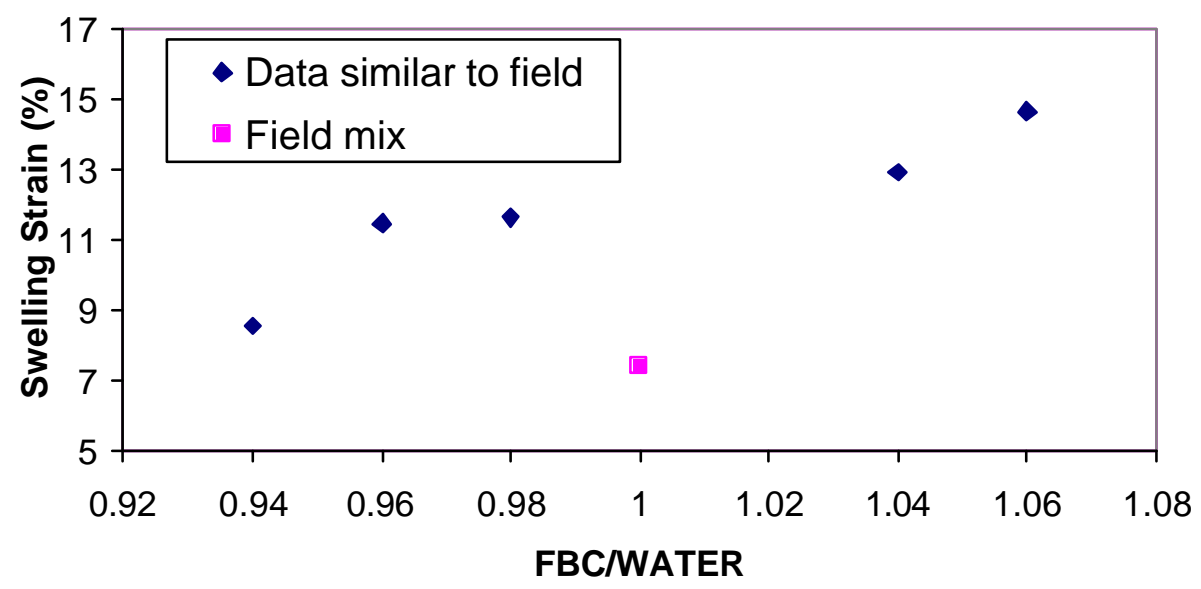

Figure 22. Variation in swelling strain with FBC/WATER ratio.

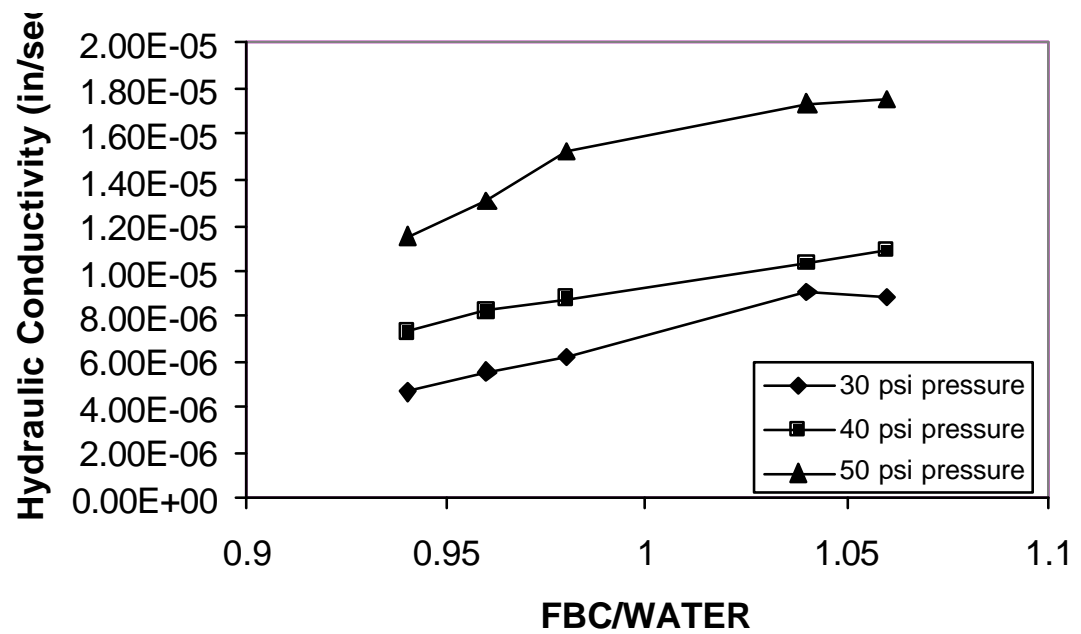

Figure 23. Variations in hydraulic conductivity with FBC/WATER.

Comparison of Compressive Strength and Elastic Modulus for Field Samples and Developed Statistical Model from Laboratory Samples: Tables 11 and 12 show 7 day, and 28-day cured compressive strength and elastic properties of field samples along with prediction limits from the regression models, respectively. In the field operation, FBC/WATER ratio was kept around one (1). It is seen that in most of the cases the actual values lie within the $95 \%$ prediction limits. As mentioned earlier, the strength and modulus values of 28-day cured sample are less than those of laboratory specimens of 300 to $400 \mathrm{psi}$ due to the larger gob particles and more water in the samples. 
Table 10. Actual compressive strength and elastic modulus of 18-month (560 days) cured field samples.

\begin{tabular}{|c|c|c|}
\hline Sample & Strength, psi & Elastic Modulus, psi \\
\hline 1 & 294 & 65,136 \\
\hline 2 & 789 & $1,34,192$ \\
\hline 3 & 594 & 58,546 \\
\hline
\end{tabular}

Table 11. Actual and predicted compressive strength and elastic modules of 7-day cured field samples.

\begin{tabular}{|l|l|l|l|l|}
\hline Sample & $\begin{array}{c}\text { Strength } \\
\text { psi }\end{array}$ & $\begin{array}{c}\text { Strength } \\
\text { Predicted, psi }\end{array}$ & $\begin{array}{c}\text { Elastic } \\
\text { Modulus } \\
\text { psi }\end{array}$ & $\begin{array}{c}\text { Elastic } \\
\text { Modulus } \\
\text { Predicted, psi }\end{array}$ \\
\hline 1 & 93 & $94 \sim 219$ & 6,000 & $8,868 \sim 18,577$ \\
\hline 2 & 112 & $94 \sim 219$ & 10,000 & $8,868 \sim 18,577$ \\
\hline 3 & 112 & $94 \sim 219$ & 8,750 & $8,868 \sim 18,577$ \\
\hline 4 & 112 & $94 \sim 219$ & 7,500 & $8,868 \sim 18,577$ \\
\hline 5 & 93 & $94 \sim 219$ & 7,500 & $8,868 \sim 18,577$ \\
\hline 6 & 131 & $94 \sim 219$ & 7,500 & $8,868 \sim 18,577$ \\
\hline 7 & 93 & $94 \sim 219$ & 6,000 & $8,868 \sim 18,577$ \\
\hline 8 & 112 & $94 \sim 219$ & 7,500 & $8,868 \sim 18,577$ \\
\hline 9 & 149 & $94 \sim 219$ & 10,000 & $8,868 \sim 18,577$ \\
\hline 10 & 112 & $94 \sim 219$ & 9,375 & $8,868 \sim 18,577$ \\
\hline 11 & 93 & $94 \sim 219$ & 8,751 & $8,868 \sim 18,577$ \\
\hline
\end{tabular}

Trace Element Concentration in Field Mix Leachate: The ASTM shake test was performed for the field mix to obtain elemental concentration (in ppm) of various trace elements. Table 13 compares data for individual components and the field mix. This table also provides Class I ground water $(\mathrm{GW})$ standards for comparison. Most of the trace elements the field mix contains are bwer amount than the standard. Thus, the injected grout underground is an environmentally benign mix. The $\mathrm{pH}$ of the mix is also on the alkaline side indicating that the acidic gob is neutralized. The mixes were designed with $25 \%$ more alkalinity than would be required to neutralize all the acidity due to gob in the mix. 
Table 12. Actual and predicted compressive strength and elastic modules of 28-day cured field samples.

\begin{tabular}{|l|l|l|l|l|}
\hline Sample & $\begin{array}{c}\text { Strength } \\
\text { psi }\end{array}$ & $\begin{array}{c}\text { Strength } \\
\text { Predicted, psi }\end{array}$ & $\begin{array}{c}\text { Elastic } \\
\text { Modulus } \\
\text { psi }\end{array}$ & $\begin{array}{c}\text { Elastic Modulus } \\
\text { Predicted, psi }\end{array}$ \\
\hline 1 & 168 & $203 \sim 457$ & 13,333 & $11,238 \sim 29,647$ \\
\hline 2 & 187 & $203 \sim 457$ & 10,526 & $11,238 \sim 29,647$ \\
\hline 3 & 261 & $203 \sim 457$ & 23,273 & $11,238 \sim 29,647$ \\
\hline 4 & 224 & $203 \sim 457$ & 21,667 & $11,238 \sim 29,647$ \\
\hline 5 & 168 & $203 \sim 457$ & 18,571 & $11,238 \sim 29,647$ \\
\hline 6 & 131 & $203 \sim 457$ & 16,000 & $11,238 \sim 29,647$ \\
\hline 7 & 168 & $203 \sim 457$ & 18,600 & $11,238 \sim 29,647$ \\
\hline 8 & 242 & $203 \sim 457$ & 20,833 & $11,238 \sim 29,647$ \\
\hline 9 & 206 & $203 \sim 457$ & 22,203 & $11,238 \sim 29,647$ \\
\hline 10 & 224 & $203 \sim 457$ & 22,982 & $11,238 \sim 29,647$ \\
\hline 11 & 280 & $203 \sim 457$ & 10,273 & $11,238 \sim 29,647$ \\
\hline 12 & 149 & $203 \sim 457$ & 10,500 & $11,238 \sim 29,647$ \\
\hline 13 & 243 & $203 \sim 457$ & 22,301 & $11,238 \sim 29,647$ \\
\hline 14 & 206 & $203 \sim 457$ & 15,625 & $11,238 \sim 29,647$ \\
\hline 15 & 187 & $203 \sim 457$ & 22,727 & $11,238 \sim 29,647$ \\
\hline
\end{tabular}




\section{AN ANALYSIS OF THE EFFECT OF BACKFILLING ON WEAK FLOOR AND COAL PILLAR STABILITY}

Subsidence associated with weak floor strata deformation is a well recognized proble $m$ in the Illinois Coal Basin. One of the objectives of this project was to stabilize mine openings and coal pillars through backfilling so that potential for future subsidence is minimized. The No 6 coal seam at Crown III mine is associated with 2.0 to 4.5 feet of weak floor strata which is known to result in a small amount of floor heave after mining a panel even with $55 \%$ extraction ratio. Increasing the extraction ratio further will increase the potential for floor heave and surface deformations. Backfilling the voids increases the stability of mine openings as well as coal pillars. Coal pillar stability is enhanced through confining pressure on pillar ribs while opening stability is enhanced through reduced water permeability to weak floor strata, and increased resistance to shear movement through stiff backfill. Degradation of weak floor strata through increased moisture content is significantly reduced which promotes the load carrying capacity of floor strata. Finally, backfilling also reduces the chance of water inrush into the panel. The stability of the panel should reduce water drainage from overlying and underlying strata into mine workings.

Table 13. Elemental concentrations (in ppm) in the leachate of ASTM shake test

\begin{tabular}{|l|l|l|l|l|l|l|}
\hline Element & Class I & $\begin{array}{l}\text { Detection } \\
\text { Limit }\end{array}$ & $\begin{array}{l}\text { F ash } \\
\text { Coffeen } \\
\text { Fly Ash }\end{array}$ & Gob & $\begin{array}{l}\text { FBC } \\
\text { ADM } \\
\text { Fly Ash }\end{array}$ & Field Mix \\
\hline $\mathrm{Ag}$ & 0.05 & 0.007 & 0 & 0.01 & 0 & 0.01 \\
\hline $\mathrm{Al}$ & & 0.045 & 0.24 & 0.03 & 0.02 & 0.13 \\
\hline $\mathrm{As}$ & 0.05 & 0.053 & 0.04 & 0 & 0 & 0.01 \\
\hline $\mathrm{B}$ & 2 & 0.012 & 23.39 & 0.04 & 0.53 & 1.35 \\
\hline $\mathrm{Ba}$ & 2 & 0.0013 & 0.01 & 0.08 & 0.10 & 0.12 \\
\hline $\mathrm{Be}$ & 0.004 & 0.00027 & 0 & 0 & 0 & 0.004 \\
\hline $\mathrm{Ca}$ & & 0.010 & 241 & 368 & 1163 & 669 \\
\hline $\mathrm{Cd}$ & 0.005 & 0.0025 & 0 & 0.01 & 0 & 0 \\
\hline $\mathrm{Co}$ & 1 & 0.007 & 0 & 0.10 & 0 & 0.01 \\
\hline $\mathrm{Cr}$ & 0.1 & 0.0061 & 0.06 & 0.05 & 0.08 & 0.02 \\
\hline $\mathrm{Cu}$ & 0.65 & 0.0054 & 0 & 0.06 & 0.09 & 0.01 \\
\hline $\mathrm{Fe}$ & 5 & 0.012 & 0.02 & 0 & 0 & 0 \\
\hline $\mathrm{Mg}$ & & 0.00015 & 6.93 & 25 & 0.17 & 0.45 \\
\hline $\mathrm{Mn}$ & 0.15 & 0.0014 & 0 & 2.28 & 0 & 0.04 \\
\hline $\mathrm{Mo}$ & & 0.012 & 1.12 & 0 & 0.09 & 0.04 \\
\hline $\mathrm{Ni}$ & 0.1 & 0.015 & 0.04 & 1.24 & 0.03 & 0.01 \\
\hline $\mathrm{Pb}$ & 0.0075 & 0.042 & 0 & 0 & 0 & 0 \\
\hline $\mathrm{Sb}$ & 0.006 & 0.032 & 0.06 & 0.05 & 0.04 & 0 \\
\hline $\mathrm{Se}$ & 0.05 & 0.075 & 0.06 & 0.20 & 0 & 0.02 \\
\hline $\mathrm{Ti}$ & 0.002 & 0.120 & 0.01 & 0.01 & 0.02 & 0.01 \\
\hline $\mathrm{V}$ & & 0.0075 & 0 & 0 & 0 & 0.03 \\
\hline & & & & & & \\
\hline
\end{tabular}




\begin{tabular}{|l|l|l|l|l|l|l|}
\hline Zn & 5 & 0.0018 & 0.07 & 1.96 & 0.67 & 0 \\
\hline Sulfate & 400 & 50 & 857 & 688 & 1140 & 948 \\
\hline TDS & 1200 & & 942 & 1247 & 6850 & 1540 \\
\hline pH & & & 8.8 & 3.2 & 12.8 & 11.23 \\
\hline
\end{tabular}

A ' 0 ' in a cell indicates below detection limit of ICP

\section{Analytical Studies}

The effect of backfilling on mine stability was analyzed with the SIUPANEL.3D program modified for backfilling analysis and verified by the finite element method. The details of the development of a 3D structural analysis model (SIUPANEL.3D) that can efficiently determine the effect of backfilling on the stability of a room and pillar mining system are discussed here. Further verification of the hypothesis adopted in the 3D structural model with backfilling was required using the finite element method. The results of these studies are presented in the following sections.

SIUPANEL3D Analytical Model: This analytical model (Pytel and Chugh, 1990) is based on the flexural theory of thin plates resting on inelastic foundations. The physical problem consisting of overburden plates, coal seam, and floor strata is transformed into an equivalent mechanistic problem. The system is divided into small blocks through a grid network depending on the size of pillars and openings. Each block may have different coal measure rock properties and loading conditions. The overburden strata associated with the coal seam is transformed into a composite plate with stepwise varying flexural stiffnesses. The uniformly distributed overburden load is transmitted to the weak floor strata through segmented rectangular footings representing panel pillars. The immediate floor stratum is modeled as an equivalent visco-elastic rock. The contact stresses at the rock-plate interface are approximated by rectangular areas of uniform stresses, which are transformed into equivalent concentrated forces acting at the center of the plan area of each element. Coal pillars are represented by a set of non-linear strings sandwiched between the upper overburden strata plate and lower deformable weak floor strata

Weak floor strength parameters in SIUPANEL.3D are determined using the two basic approaches, namely 1) Vesic model (1963) and 2) Pytel-Chugh (1991) model. The data is used to calculate traditional pillar and floor safety factors, floor bearing capacity, and the probability of the failure of pillars for the entire panel. Since geotechnical properties for geologic materials are highly variable, structural analyses in the model also involve probabilistic design. The load bearing capacity of floor strata is primarily governed by immediate floor stratum moisture content, its thickness, and its angle of internal friction, and similar data for the more competent bed below the immediate weak floor strata. The SIUPANEL.3D can provide failure probability for each pillar based on available data for the above variables.

To incorporate the effect of backfilling in room and pillar mining, a simple structural hypothesis was developed and incorporated in the SIUPANEL.3D program (Chugh, 
1999). The hypothesis postulates that backfilling redistributes the load to be carried by the backfill, which increases the effective width of the pillar and a decrease in the height of the opening. Both should result in increased safety factors for the pillar as well as for the floor. Figure 24 (A, B and C) shows the stress redistribution at different stages of mining and after backfilling. The load acting on the backfill material is due to its weight and the pressure from the sides of the pillar. No shear stress acts along the surface of the backfill. The pressure from the side of pillar is always higher than the weight of the backfill material. Therefore, the major principal stress plane is oriented along the surface of backfill material in the horizontal direction. The minor principal stress plane is perpendicular to it. Figure 25 depicts the state of stress in the backfill material by Mohr's circle. From the tria ngle $\mathrm{ABC}$, the angle, $\alpha$ can be determined as,

$$
\alpha=\frac{\pi}{4}-\frac{\phi}{2}
$$

The effective pillar width at the base due to backfilling is determined using the following formula (Figure 1),

$$
W=W_{p}+2\left[H_{f} \tan \left(\frac{\pi}{4}-\frac{\phi}{2}\right)\right]
$$

where, $\quad \mathrm{W}$ is the effective width of the pillar after backfill

$H_{f}$ is the backfill height

$W_{p}$ is the original width of the pillar

$\phi$ is the angle of internal friction of the backfill material

The effective height of excavation after backfilling is then given by,

$$
H=H_{p}-\frac{H_{f}}{3}
$$

where, $H_{p}$ is the height of the pillar.

If the backfill material is cohesive, it may bond with the pillars, or have frictional strength. The backfill material will carry some of the vertical load transmitted from the pillars. It is difficult to determine the explicit mathematical equation to represent this kind of partial load transmission mechanism. The above equations are proposed here based on simple geometric relationships and their validation was done using finite element analyses.

After backfilling, the strength of pillar is calculated using Holland's formula as mentioned below (Brady and Brown, 1985), 


$$
S=\sigma_{c} \sqrt{\frac{W_{p}+2\left[H_{f} \tan \left(\frac{\pi}{4}-\frac{\phi}{2}\right)\right]}{h}}
$$

where, $\sigma_{c}$ is the compressive strength of the critical size cube.

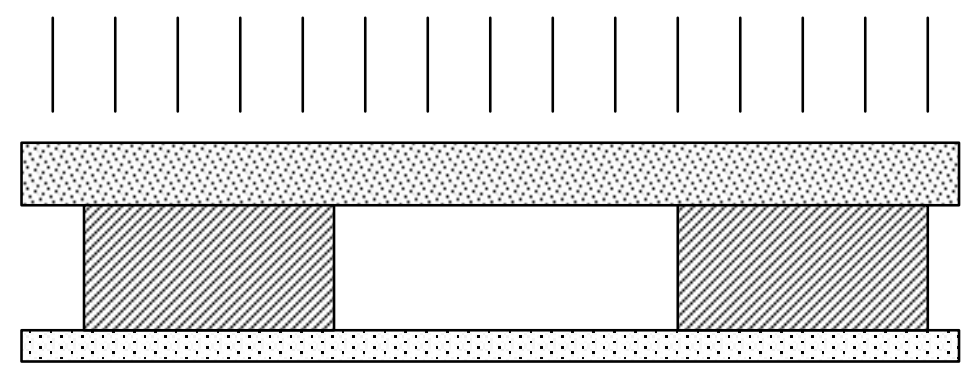

A

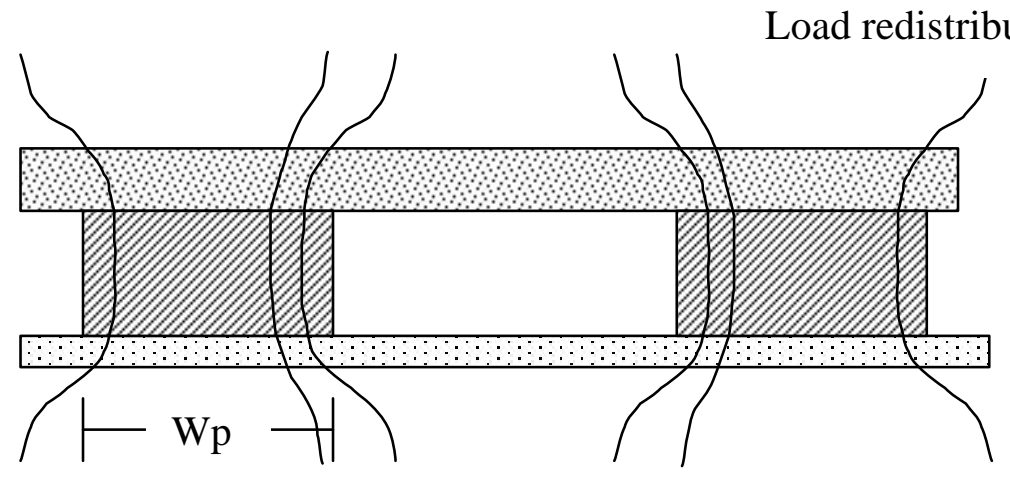

B

Load redistribution lines

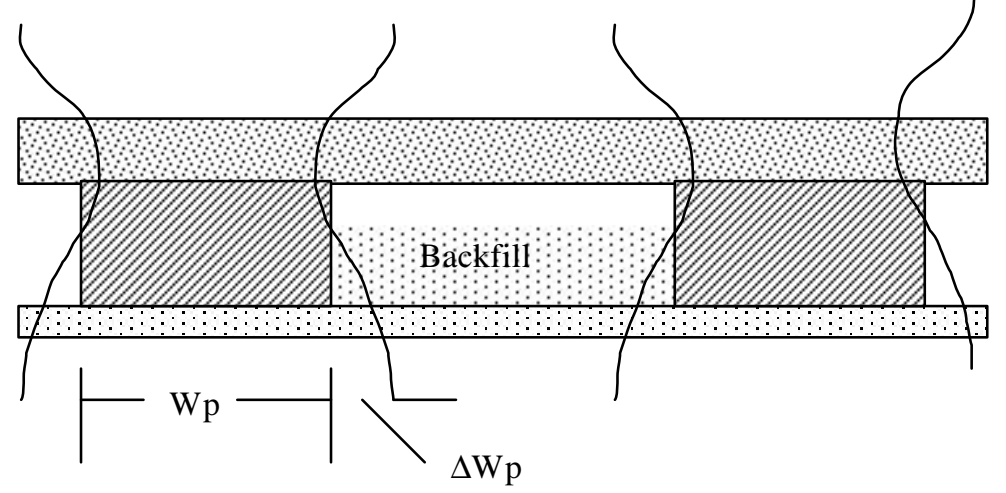

C

$\Delta \mathrm{Wp}=$ increase in pillar width due to load redistribution through backfill

Figure 24. A schematic diagram depicting stress redistribution due to backfilling (A and $\mathrm{B}=$ before backfilling; $\mathrm{C}=$ after backfilling).

The average stress acting on a pillar is given by (Brady and Brown, 1985), 


$$
\sigma_{p}=\frac{P+\partial P}{\left[W_{p}+2\left\{H_{f} \tan \left(\frac{\pi}{4}-\frac{\phi}{2}\right)\right\}\right]\left[W_{p}+2\left\{H_{f} \tan \left(\frac{\pi}{4}-\frac{\phi}{2}\right)\right\}\right]}
$$

where, $\mathrm{P}$ is the total load acting on the pillar before backfilling, and $\partial P$ is the additional load applied due to subsidence and after opening is backfilled. Using Equation (11) and (12), the improved factor of safety after backfilling is given by,

$$
\text { Pillar safety factor }=\frac{s}{\sigma_{p}}
$$

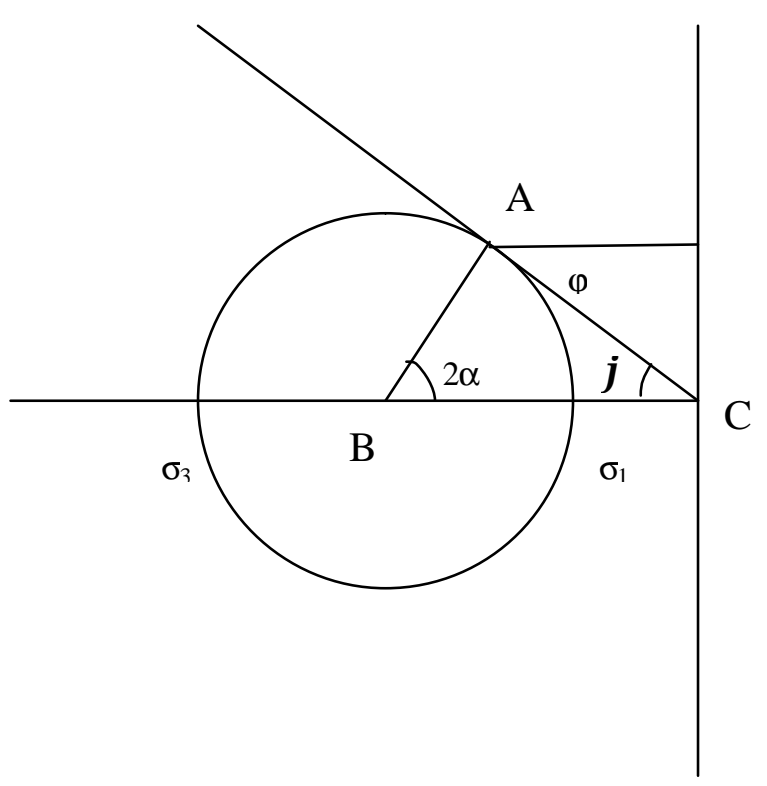

Figure 25. Mohr's circle for a theoretical backfill material.

Brown and Meyerhof (1969) proposed the following equation for the determination of bearing capacity for foundations on a soft stratum lying above a hard stratum, which is the case when the immediate floor consists of underclays overlying a harder limestone or claystone:

$$
q_{0}=s_{1} N_{m}
$$

where, $\mathrm{s}_{1}=$ unconfined shear strength of the weak stratum

$\mathrm{N}_{\mathrm{m}}=$ modified bearing capacity factor

Vesic (1970) proposed the following equation for the determination of $\mathrm{N}_{\mathrm{m}}$ : 


$$
N_{m}=\frac{K N_{c}^{*}\left(N_{c}^{*}+\beta-1\right)\left[(K+1) N_{c}^{*}+(1+K \beta) N_{c}^{*}+\beta-1\right]}{\left[K(K+1) N_{c}^{*}+K+\beta-1\right]\left[\left(N_{c}^{*}+\beta\right) N_{c}^{*}+\beta-1\right]-\left(K N_{c}^{*}+\beta-1\right)\left(N_{c}^{*}+1\right)}
$$

where, $\mathrm{K}=$ ratio of the unconfined shear strength of the lower hard layer $\left(\mathrm{S}_{2}\right)$ to the upper weak layer $\left(\mathrm{S}_{1}\right)$

$$
\begin{aligned}
& N_{c}^{*}=E_{c} N_{c ;} N_{c}^{*}=6.17 \text { for } \phi=0 \\
& \mathrm{E}_{\mathrm{c}}=\text { shape factor } \\
& \mathrm{N}_{\mathrm{c}}=\text { bearing capacity factor for the weak layer } \\
& \beta=\frac{B L}{[2(B+L) H]} \\
& \mathrm{B}=\text { width of foundation } \\
& \mathrm{L}=\text { length of foundation } \\
& \mathrm{H}=\text { thickness of the weak layer }
\end{aligned}
$$

Speck (1981) found a good correlation between the natural water content and triaxial strength of underclays. He modified Vesic's equation to include underclay content:

$q_{0}=\left(N_{m}\right)[2070-(167)(M C)](R F)$

Using Equation (12) and (18), the floor factor of safety against bearing capacity failure is given by,

$$
\text { Floor safety factor }=\frac{q_{0}}{\sigma_{p}}
$$

Model Validation: The modified SIUPANEL.3D program was validated for data from Crown III mine. The following example gives application of the updated SIUPANEL.3D program in analyzing the influence of backfilling on the pillar and floor stability. A regular mining panel is given in Figure 26 with the pillar size of $80 \mathrm{ft}$ x $80 \mathrm{ft}$ (solid), opening width of $20 \mathrm{ft}$, and extraction ratio of $55.6 \%$. The coal seam was 6.0 feet high with the overburden depth of 350 feet.

In this example, different backfill heights (backfill height/excavation height $=0,0.15$, $0.3,0.5,0.65,0.8,0.95,1.0)$ were modeled. The backfill material had an angle of internal friction of 25 degrees, unit weight of 110 pcf, cohesion of 175 psi and Poisson's ratio of 0.35 . The mean and standard deviation for input parameters are listed in Table 14.

Table 14. Input parameters for probabilistic analysis.

\begin{tabular}{|l|l|l|}
\hline Parameter & Mean & Standard-deviation \\
\hline $\mathrm{Qu}(\mathrm{psi})$ & 650 & 145 \\
\hline $\mathrm{Mc} 1 \%)$ & 8.5 & 1.0 \\
\hline $\mathrm{Mc} 2(\%)$ & 2.0 & 0.0 \\
\hline$\varnothing 1$ (degree) & 1.0 & 0.1 \\
\hline$\varnothing 2$ (degree) & 30 & 0.1 \\
\hline $\mathrm{H}$ (feet) & 4.0 & 1.0 \\
\hline
\end{tabular}


Where, $\mathrm{Qu}$ is the unconfined compressive strength

$\mathrm{Mc} 1$ is the moisture content of the weak floor strata,

Mc2 is the moisture content of the competent floor strata,

$\varnothing 1$ is the angle of internal friction of the weak floor strata,

$\varnothing 2$ is the angle of internal friction of the competent floor strata, and

$\mathrm{H}$ is the thickness of the weak floor strata

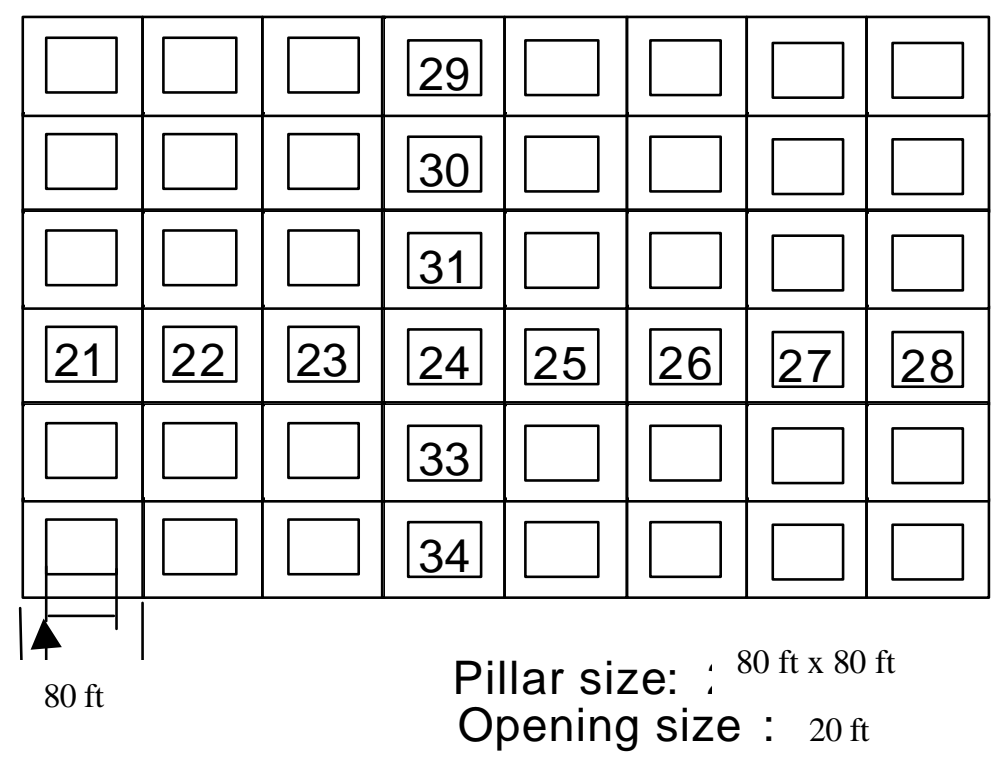

Figure 26. Room-and-Pillar mining geometry for the validation mine

The effect of backfilling was investigated for pillars 21 through 28 and pillars 29 through 34 as shown in Figure 26. The failure probability of pillar 24, located at the center of the panel is shown in Figure 27. As the backfilling height increases, the failure probability of pillar decreases. Figures 28 and 29 show the increase in safety factors and the bearing capacity, respectively of the floor as well as the pillar at pillar no. 24. Figures 28 and 29 suggest that as the backfilling height increases, the floor and pillar safety factors and the bearing capacity of floor increase. 


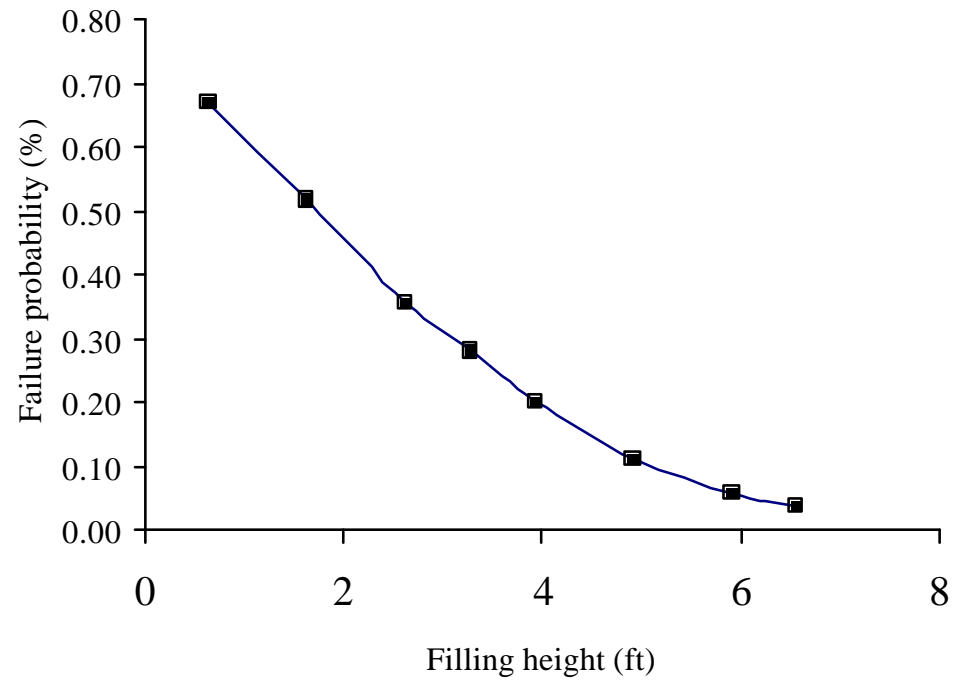

Figure 27. Influence of backfill height on failure probability of pillar 24.

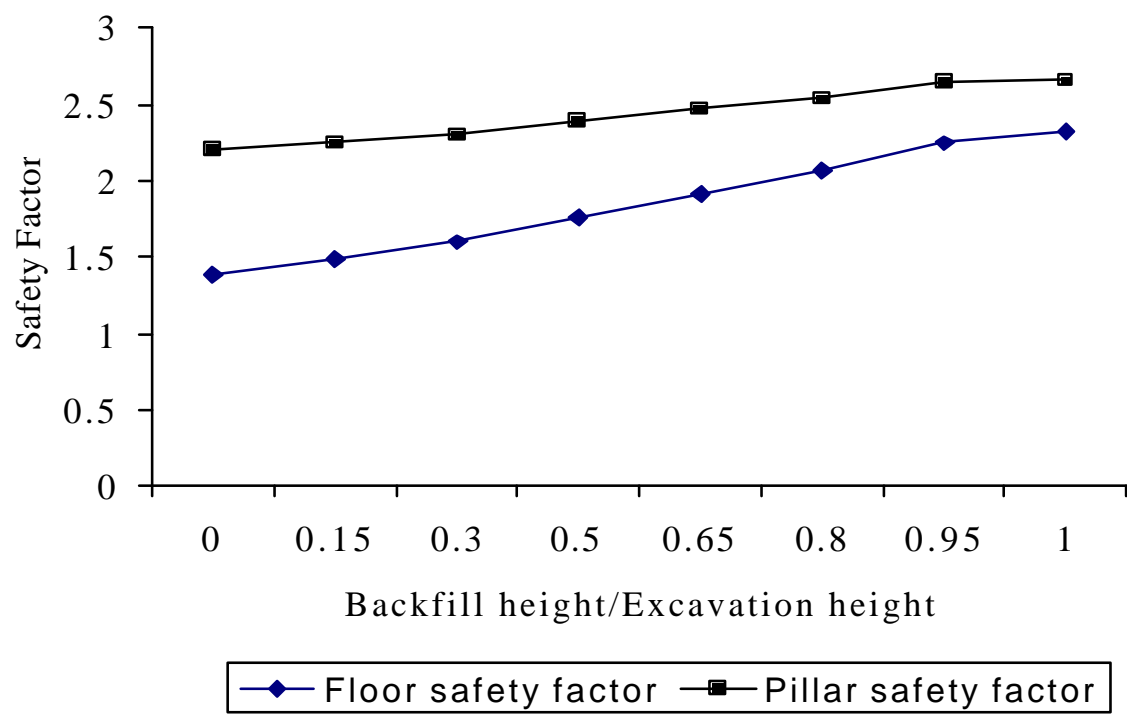

Figure 28. Variation of pillar and floor factor of safety with the backfill height 


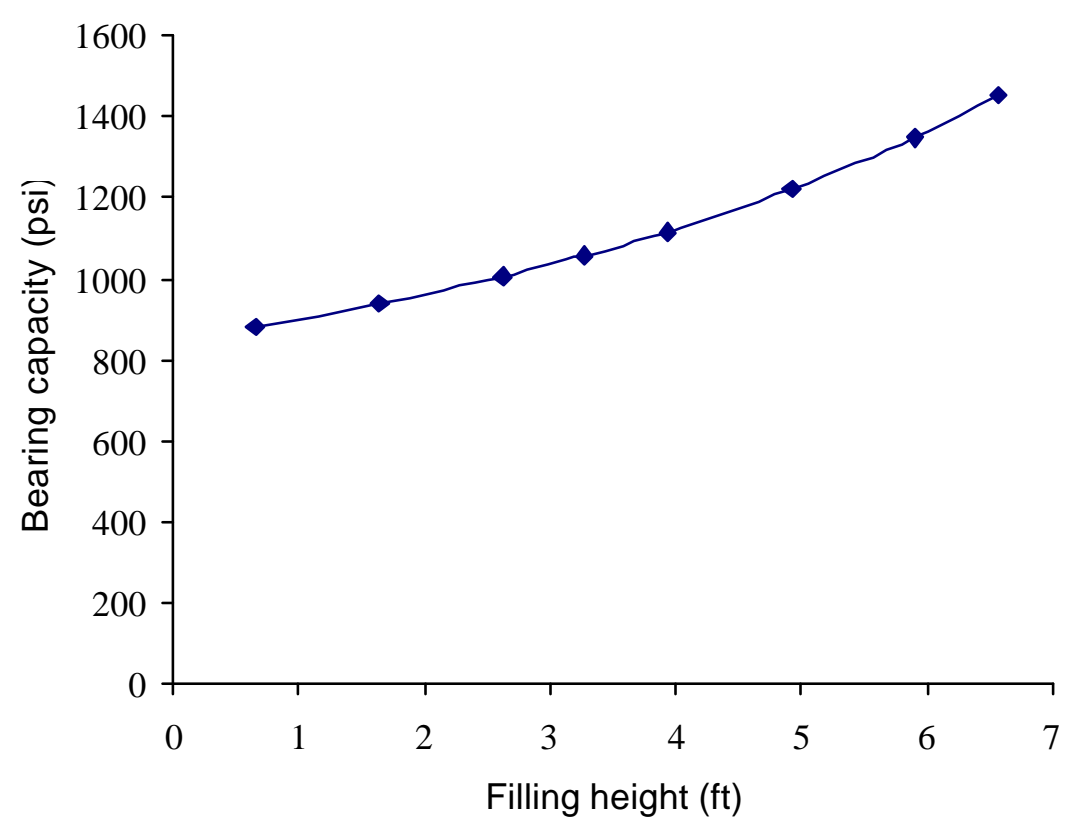

Figure 29. Variation of floor bearing capacity with backfill height.

In a practical mining situation, the center of the panel experiences the maximum overburden load. The SIUPANEL.3D program was used to investigate whether the backfilling had any significant effect at the center of the panel. Figures 30 and 31 depict the pillar and floor safety factors for the complete panel before and after backfilling operation. The results suggest that pillar safety factor improves by about $24 \%$ at the center, and by about $26 \%$ near the barrier pillar after backfilling. The floor safety factor improves by about $110 \%$ at the center, and $130 \%$ at the sides of the panel. Therefore, the backfilling has larger effect on the floor safety factor than on the pillar safety factor. The results also suggest that the improvement of safety factors after backfilling are higher near the barrier than at the center of the panel. 


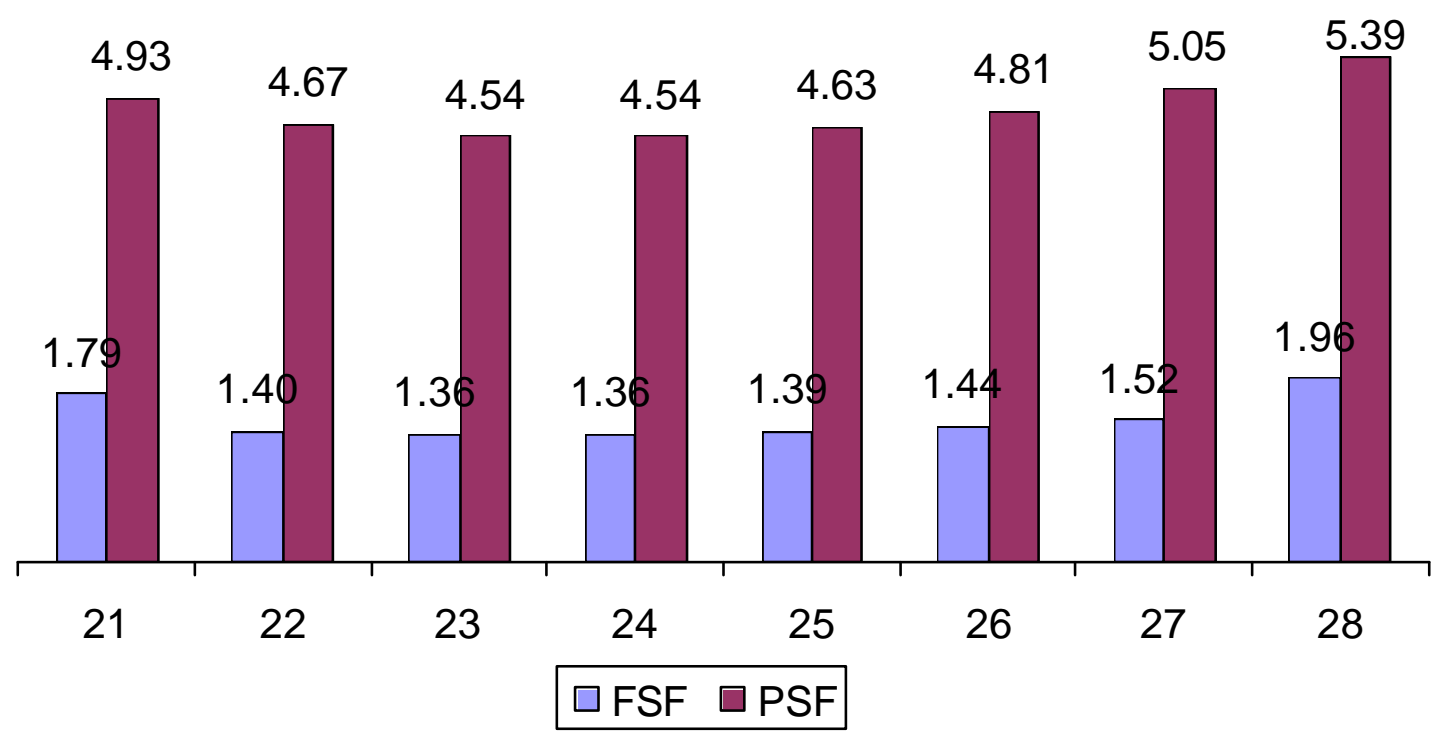

Figure 30. Variation of pillar and floor safety factors in a panel without backfilling.

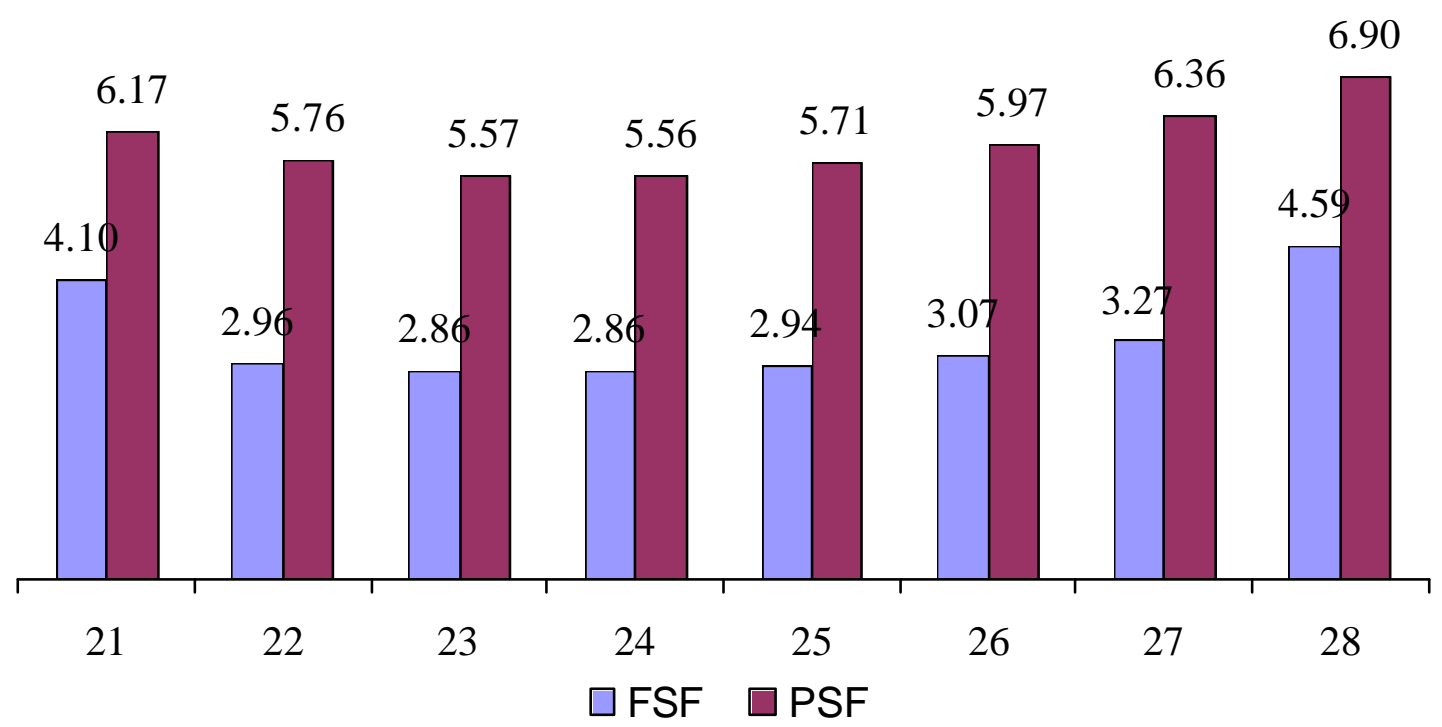

Figure 31. Variation of pillar and floor safety factors in a panel after backfilling.

\section{Validation of Modeling Hypothesis Through Finite Element Analysis}

To simulate underground room and pillar backfilling and verify Chugh's hypothesis (1999), several 2D finite element models were developed in Phase ${ }^{2}$ finite element software. The analysis was carried out for depth of 350 feet under gravity loading with the ratio of horizontal to vertical stress of $1 / 3$. The thickness of the coal seam considered, 
was 6.0 feet, with the pillar width and opening width of 80 feet (c-c) and 20 feet, respectively. Only the weak floor was considered as an isotropic and a perfectly plastic material. The immediate roof strata above the coal seam and the strong floor strata underneath the weak floor stratum were considered as isotropic, homogeneous and elastic material. The strengths of the different materials were computed using the Hoek-Brown failure criteria.

Analysis Methodology: The two-dimensional, linear elastic-plastic finite element method was selected to investigate the behavior of consolidated backfill in room and pillar mining. Stress concentrations around an excavation in two-dimensions is larger than that analyzed in three-dimensions cases. The performance of backfill in twodimensional cases can also be safely correlated to the equivalent three-dimensional cases (Yun-Yan, et al., 1983).

Simulation was done for the weak floor strata condition. Since we are most interested in ultimate deformation rather than time-dependent deformations, the immediate floor beneath the coal seam was considered as a plastic material. The aim of this study was to show that the when the excavation was backfilled with a filling material to different heights the filling material would carry some vertical load at both sides of the backfill near the pillar ribs.

The analyses were carried out for five different stages in the mining process. In the first stage, modeling without mine openings was considered. The other four stages were analyzed with respect to this base case. In the second stage, an excavation 6.0 feet high and 20 feet wide was created. In each of the third, fourth and fifth stages, the excavation was backfilled with the filling heights of 1.5 feet, 3.0 feet and 4.0 feet, respectively. In case of the backfill material, the initial element loading was achieved through body force only, whereas for other rock masses in the roof, floor and coal seam, it was achieved through both field stress and body force.

As might be expected, the backfill material will not assume any load, unless a small surface load (traction) or nodal displacement is applied at the ground surface level. Since it was convenient to apply traction in Phase $^{2}$ instead of nodal displacement, traction equivalent to 4 inches of displacement at the ground surface level was applied at stages 3 , 4 and 5. To calculate the equivalent traction (i.e., traction equivalent to 4 inches), average elastic modulus was computed first. Then, the strain was calculated as the ratio of displacement (4 inches) to the model height. Finally, the traction was computed as the product of the average elastic modulus and strain. Phase ${ }^{2}$ uses traction per meter depth, and therefore, it was computed as $0.89 \mathrm{MN} / \mathrm{m}$. In each new case, the model adjusted to the new conditions and calculations continued until the unbalanced load approached zero.

Results and Discussions: Differential stresses and displacements with respect to the first stage (unmined case model) were computed. This was done to eliminate the elastic rebound at the near surface level. Figures 32 and 33 denote contours of major principal stress $\left(\sigma_{1}\right)$ and minor principal stress $\left(\sigma_{3}\right)$, respectively. In the figures, different stages are shown by $\mathrm{A}, \mathrm{B}, \mathrm{C}$ and $\mathrm{D}$, that is, $\mathrm{A}$ denotes an excavation only, B denotes an 
excavation with backfill height of $1.5 \mathrm{ft}, \mathrm{C}$ denotes an excavation with backfill height of $3.0 \mathrm{ft}$, and D denotes an excavation with backfill height of $4.0 \mathrm{ft}$. At stage $1, \sigma_{1}$ varied from 745 psi to 1,005 psi along the sides of pillar (Figure $32 \mathrm{~A}$ ). There was high stress concentration of 1,263 psi to 1,523 psi in the pillar near the roof level. Along the sides of a pillar, $\sigma_{1}$ acted vertically downwards (Figure $32 \mathrm{~A}$ ). The stress trajectories of both the major and minor principal stresses were superimposed on the major principal stress contour. The long axis represents the orientation and the value of the major principal stress $\left(\sigma_{1}\right)$ and the short axis represents orientation and the value of the minor principal stress $\left(\sigma_{3}\right)$. At stage $2, \sigma_{1}$ varied from 850 psi to 1,655 psi at the sides of the pillar. At this stage, backfill material carried some load at both the sides in the range of $445 \mathrm{psi}$. At the center of the backfill material, it had no load. The high stress at the sides of the backfill-material was due to the effect of lateral pressure offered by the pillar. The orientations of principal stress trajectories showed that they made an angle with the vertical in the backfill material. This angle was calculated, and was found to be 32.5 degrees (Figure $32 \mathrm{~B}$ ). However, on closer inspection, it was found that the angle was not constant, rather it varied with depth of the backfill material. This is because the principal stresses in the different layers of the backfill material were not constant. The major principal stress $\left(\sigma_{1}\right)$ at the top layer of the backfill material was approximately $0.30 \mathrm{psi}$, and at the bottom layer of the backfill material it was approximately $168 \mathrm{psi}$. The minor principal stress $\left(\sigma_{3}\right)$ at the top layer of the backfill material was approximately $1.2 \mathrm{psi}$, and at the bottom layer of the backfill material it was approximately $45 \mathrm{psi}$. Due the varying stress at different layers of the backfill material, the Mohr's envelope would be a curved line, leading to a varying angle. However, for approximation, the average value of 32.5 degrees can be used.

At the center of the backfill material, the principal stress trajectories were horizontal. This was because of the horizontal pressure from the pillar ribs. At this point, the vertical stress was due to gravity. Further increase of backfill height to $3.0 \mathrm{ft}$ showed the zone of high $\sigma_{1}$ values at the sides of the backfill material. The directions of stress trajectories remained the same (Figure $32 \mathrm{C}$ ). At even higher backfill height (Figure $32 \mathrm{D}$ ) of $4.0 \mathrm{ft}$, there was no increase of $\sigma_{1}$ values along the sides of the backfill material. Nevertheless, at the upper layer of the material, horizontal pressure offered by pillar was less than the vertical stress of the backfill material. This was because, the excavation was deformed and the load from upper strata acted on the backfill material. Figure 32 shows that at about $50 \%$ of the backfill height, the backfill material carried maximum load along its sides. From the angle of stress trajectories and the backfill height, the effective increase in pillar width was determined. 

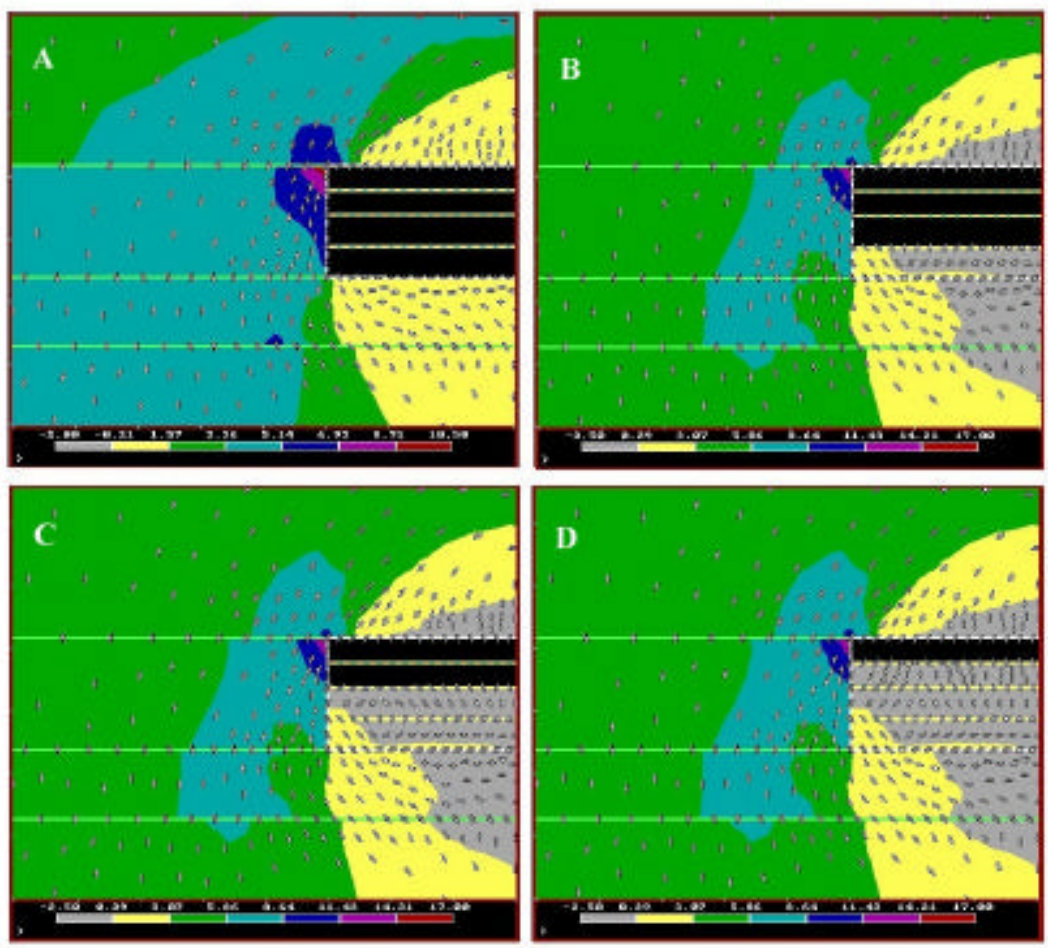

Figure 32. The contour of major principal stress $\left(\sigma_{1}\right)$ at four different stages.
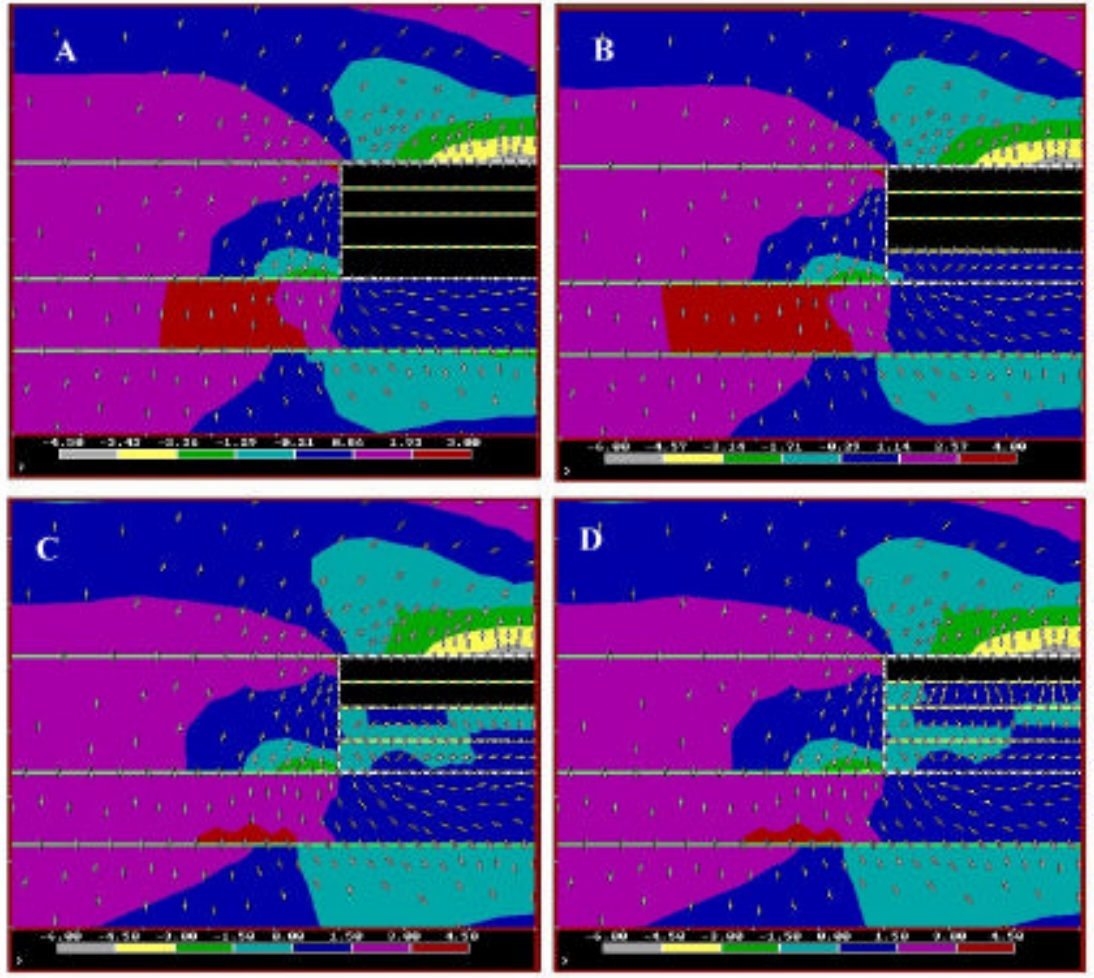

Figure 33. The contour of minor principal stress $\left(\sigma_{3}\right)$ at four different stages. 


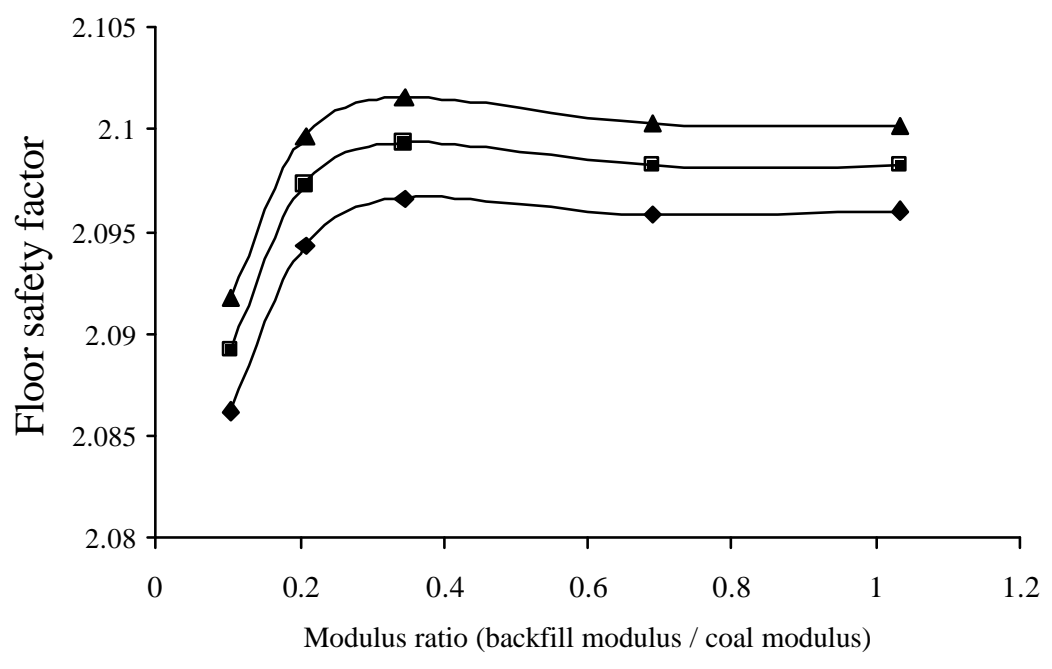

$\multimap$ Fill height $=0.5 \rightarrow-$ Fill height $=1.0 \multimap-$ Fill height $=1.5$

Figure 34. The effect of modulus ratio on floor safety factors.

From the analysis of finite element modeling, the effect of modulus ratio (ratio of the backfill modulus to coal modulus) on the floor safety factor was investigated. Figure 34 shows the effect of modulus ratio on the floor safety factor as well as on the backfill heights. At modulus ratio of 0.3, the safety factor increases rapidly. Beyond this point, it remains constant. Therefore, the optimum value of the backfill modulus can be taken as $1 / 3$ of the coal modulus. 


\section{ENGINEERING ECONOMIC ANALYSIS}

An engineering economic analysis was conducted on the feasibility of managing coal processing waste and coal combustion by-products into an active underground mine with extraction of additional coal through design of short-life pillars. This analysis was based on site specific location at Freeman United Coal Company's (Freeman) Crown III Mine located near Farmersville, IL. The following assumptions were made in the analysis:

1. Revenue from CCBs management - $\$ 5.00 /$ ton

2. Selling price of coal - $\$ 18.00 /$ ton

3. Incremental production cost of coal - $\$ 9.00 /$ ton

4. Amount of gob managed annually - 550,000 tons

5. Amount of FBC ash managed/year - 800,000 tons

6. Only panels will be backfilled and efficiency of backfilling will be $80 \%$.

7. For a panel 900 feet wide, two boreholes will be drilled for injection. Each borehole will have an influence area of $450 \mathrm{ft}$ x $450 \mathrm{ft}$. Thus, backfill will be expected to flow about 300 feet all around an injection borehole.

8. Each injection borehole will be steel cased throughout the length of borehole.

9. Land acquisition cost of $\$ 3,000 /$ acre.

10. Underground injection royalty cost of $\$ 0.15 /$ ton

11. The backfill system will be designed for 200 tons per hour peak backfill rate. Three injection boreholes will be operating at any one time.

12. The backfill will be dry mixed near the processing plant, transported in offhighway trucks to the injection borehole where water will be mixed with it and the backfill will be placed underground without pumping.

13. Coal recovery will be increased about $8 \%$.

14. Road development cost for truck transport is included. Water pipelines will be laid along the developed roads for water transport.

15. Analysis was performed for 15 year project life.

16. Approximate cost of cored borehole - $\$ 10,000$.

Table 15 shows the capital requirements for this project totaled $\$ 12.5$ million, which includes the following: 
Table 15. Capital cost requirements for backfilling project.

\begin{tabular}{|l|c|c|}
\hline Item & Amount (\$) & Years spent \\
\hline Ash Plant & $5,000,000$ & 1 \\
Ash/ slurry pond & $1,500,000$ & 1 \\
Equipment & $1,625,000$ & 1 \\
Equipment & $1,400,000$ & 5 \\
Equipment & $1,625,000$ & 10 \\
Equipment & $1,400,000$ & 15 \\
Total & $12,550,000$ & \\
\hline
\end{tabular}

Of this total $\$ 8,125,000$ was considered initial capital, which was spent in Year 1. The remaining capital $(\$ 4,425,000)$ was replacement capital for the equipment during later years. Table 16 shows the operating cost requirements for the backfilling project. The estimated operating cost totaled $\$ 5.99$ per ton.

Table 16. Breakdown of operating costs.

\begin{tabular}{|c|c|}
\hline Item & Amount (\$) \\
\hline Land & 810,000 \\
\hline Royalty & 200,000 \\
\hline Trucking & $1,780,000$ \\
\hline Road development & 375,000 \\
\hline Site development & 610,000 \\
\hline Site setup & 65,000 \\
\hline Site operation & $1,110,000$ \\
\hline Site tear down & 65,000 \\
\hline Site reclamation & 200,000 \\
\hline Road reclamation & 375,000 \\
\hline Subtotal & $5,590,000$ \\
\hline Ash plant & $1,800,000$ \\
\hline Subtotal & $7,390,000$ \\
\hline Contingency (20\%) & 700,000 \\
\hline Total & $\$ 8,090,000$ \\
\hline
\end{tabular}

The coal company also sought the professional services of an independent consultant to perform economic feasibility of the project in 2001. The results are summarized below.

\section{Results of Engineering Economic Analysis}

1. The costs for surface management are slightly lower than underground management $(\$ 5.99 /$ ton $)$. However, this could change as experience is gained with underground management. 
2. Land and site development costs at this site are high because of prime agricultural lands involved. If these costs can be reduced, underground management costs may be lower than surface management cost. This could be achieved by initially backfilling areas where land is controlled by the Company.

3. Underground management minimizes slurry and gob areas development, management, and closure costs. However, underground management requires modification of the coal processing plant to handle and process gob as part of the backfill mix.

4. Each site must be evaluated separately for short-term and long-term costs involved. Underground management has significant potential particularly for new mines which have long life.

5. The Company has interest in commercializing the paste backfill technology if capital requirements can be met. The pending review of environmental issues associated with mine fills by the U.S. Environmental Protection Agency is creating some uncertainty.

A recent report by the National Academy of Engineering recommends research into alternate methods of managing coal processing waste. Underground management of coal processing waste in conjunction with coal combustion byproducts is an environmentally sound approach to minimize waste pond development, acid mine drainage, and surface subsidence. 


\section{GROUT FLOW SIMULATION IN UNDERGROUND MINE WORKINGS}

Introduction: An economic evaluation of mine backfilling in this and earlier studies indicates that the amount of grout injected through each borehole is an important variable. This is particularly true where prime agricultural lands are involved, since the land acquisition and reclamation costs are very high. Therefore, a tho rough understanding of grout flow in underground partial extraction mine workings is extremely important. Stiles (1999) of the West Virginia University developed an approximate mathematical model of grout flow in room-and-pillar mine workings. This portion of the study was undertaken to develop a better understanding of grout flow in room-and-pillar coal mine workings typically encountered in Illinois. It was thought that this study would help to optimize spacing between boreholes for mine backfilling projects.

Task Objectives: The overall goal of this task was to develop a better understanding of grout flow phenomenon in flat and slightly pitching coal seams and relative importance of variables, such as grout yield stress, grout hardening, and slope of the coal seam. The specific objectives of the task were:

1. To study grout flow phenomenon in a single entry and three-entry, and develop a sensitivity analysis of different variables such as pumping rate, grout yield, stress, entry slope, and grout hardening.

2. To simulate grout flow in the demonstration panels at Crown III mine of Freeman United Coal Company.

Groutnet Mathematical Simulation Model: The program Groutnet was specifically developed to simulate injection of high solids concentration grouts into underground room-and-pillar mines (Stiles, 1999). The model permits solution of highly complex problem in a very reasonable length of time as compared to more precise models such as Atkinson (1995) and Reddy (1997). These authors utilized a commercial computer program Phoenix. The mathematical analysis utilizes simplified three-dimensional flow equations to study flow of Bingham and Newtonian fluids in open channels. In contrast, Groutnet utilized finite difference approximations to solve the simplified equations. In brief, Groutnet offers the following significant capabilities:

- Injection in partial extraction mine workings with variable slope of the floor in both directions,

- Variable shear stress of grout as a function of time,

- Grout hardening at the end of each work period,

- No slip boundary conditions along the excavation walls,

- Variable plastic viscosity,

- Turbulent flow criterion. 
A more detailed discussion of the theory and computer program development is given in Stiles (1999).

In practical situations, the program, Groutnet can be used to analyze the spread of grout and carry out the sensitivity analyses on the following:

- Location of the bore-hole for grout injection,

- Rheological and material properties of the injected grout,

- Rate of grout hardening,

- Effect of mine geometry,

- Effect of mine floor slope,

- Effect of working and rest period,

- Rate of grout injection.

To investigate the sensitivity analyses of the above parameters for the spread of grout in the Crown III room and pillar mine, several simulations were conducted for single entry, three entry and full-scale underground mine situations. The results of these analyses are presented in the following sections.

Description of the Developed Models: The simulations were conducted for single entry, three-entry and full-scale underground mine situations. Figure 35 AB shows the layout of the single entry system and its Groutnet equivalent, respectively.

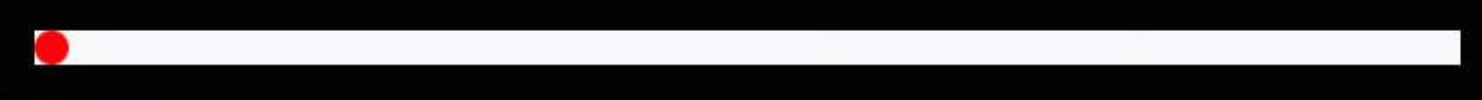

A Injection cell

$\begin{array}{lllllllllllllllllllllllllllllllllllllll}0 & 0 & 0 & 0 & 0 & 0 & 0 & 0 & 0 & 0 & 0 & 0 & 0 & 0 & 0 & 0 & 0 & 0 & 0 & 0 & 0 & 0 & 0 & 0 & 0 & 0 & 0 & 0 & 0 & 0 & 0 & 0 & 0 & 0 & 0 & 0 & 0 & 0 & 0\end{array}$ $\begin{array}{lllllllllllllllllllllllllllllllllllllllll}0 & 1 & 1 & 1 & 1 & 1 & 1 & 1 & 1 & 1 & 1 & 1 & 1 & 1 & 1 & 1 & 1 & 1 & 1 & 1 & 1 & 1 & 1 & 1 & 1 & 1 & 1 & 1 & 1 & 1 & 1 & 1 & 1 & 1 & 1 & 1 & 1 & 1 & 0\end{array}$ $\begin{array}{llllllllllllllllllllllllllllllllllllllll}0 & 0 & 0 & 0 & 0 & 0 & 0 & 0 & 0 & 0 & 0 & 0 & 0 & 0 & 0 & 0 & 0 & 0 & 0 & 0 & 0 & 0 & 0 & 0 & 0 & 0 & 0 & 0 & 0 & 0 & 0 & 0 & 0 & 0 & 0 & 0 & 0 & 0 & 0\end{array}$ B

Entry (active cell denoted by 1)

Boundary (inactive cell)

Injection cell (active cell)

Dimension of model cell $=20 \mathrm{ft} \times 20 \mathrm{ft}$

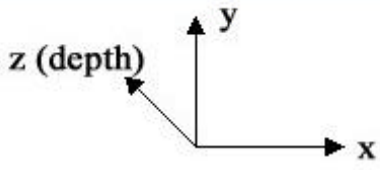

Ceiling height $=6 \mathrm{ft}$

Figure 35. Physical channel (A) and its Groutnet equivalent model (B) for the singleentry system. 
In single entry model, the total number of cells used in the horizontal and vertical directions, respectively were 100 and 3. Width of each cell considered, was $6.096 \mathrm{~m} \mathrm{(20}$ $\mathrm{ft})$. The active cells through which the grout flows are represented by 1 , and the boundary and inactive cells are represented by 0 . Therefore, a total of 98 active cells were used to model the $597.40 \mathrm{~m}$ (1960 ft) of channel (in Figure 35, only 37 active model cells are shown due to page constraints). The height of the channel considered was $1.8288 \mathrm{~m}$ (6 $\mathrm{ft})$. The injection cell was located at the left- middle cell designated by column 2 and row 2 , and marked by red dot. In the first model, the slope of the channel considered, was taken 0 degree in both the $\mathrm{x}$ and $\mathrm{y}$ directions, and the rate of grout injection was 0.01716 $\mathrm{m}^{3} / \mathrm{s}$ (120 tons/ hour). In the second model, a $1 \%$ slope was introduced with the same rate of grout injection. Then in the next models, the injection rate was varied to $0.01716 \mathrm{~m}^{3} / \mathrm{s}$ (120 tons/ hour), $0.02152 \mathrm{~m}^{3} / \mathrm{s}$ (150 tons/ hour) and $0.0286 \mathrm{~m}^{3} / \mathrm{s}$ (200 tons/hour), and the flow behavior was plotted for continuous injection. Table 17 shows the material properties of the injected Bingham grout (fly ash, gob, and water mixture).

Figure 36 A-B shows the three-entry system and its Groutnet equivalent, respectively. In three-entry system, the number of rows and columns are 52 and 9 respectively, that is the simulation was conducted for $1000 \mathrm{ft}$ wide panel, almost half the width of the single entry system to save the simulation time. It was found that $1000 \mathrm{ft}$ long three-entry system can represent the grout flow behavior well. The number of active model cells used is 214 . Figure 36 shows the layout of the three-entry system (only 40 columns are shown due to page constraints). The injection point was located at the center of the model (i.e., row 5 and column 26, and marked by red dot), and grout was injected continuously as shown in Figure 36 . The three-entry system were also simulated as was done in case of the singleentry system using the same material properties as given in Table 17.

Besides the single entry and the three-entry system, the simulation was also conducted for full-scale mine geometry of the Crown III mine, where grout was injected. Figure 37 A and B show the mine geometry and its Groutnet equivalent model for the fult-scale grout injection model, respectively. The description of the mine was already given in the previous sections. Only the Groutnet model for this mine are discussed here. 

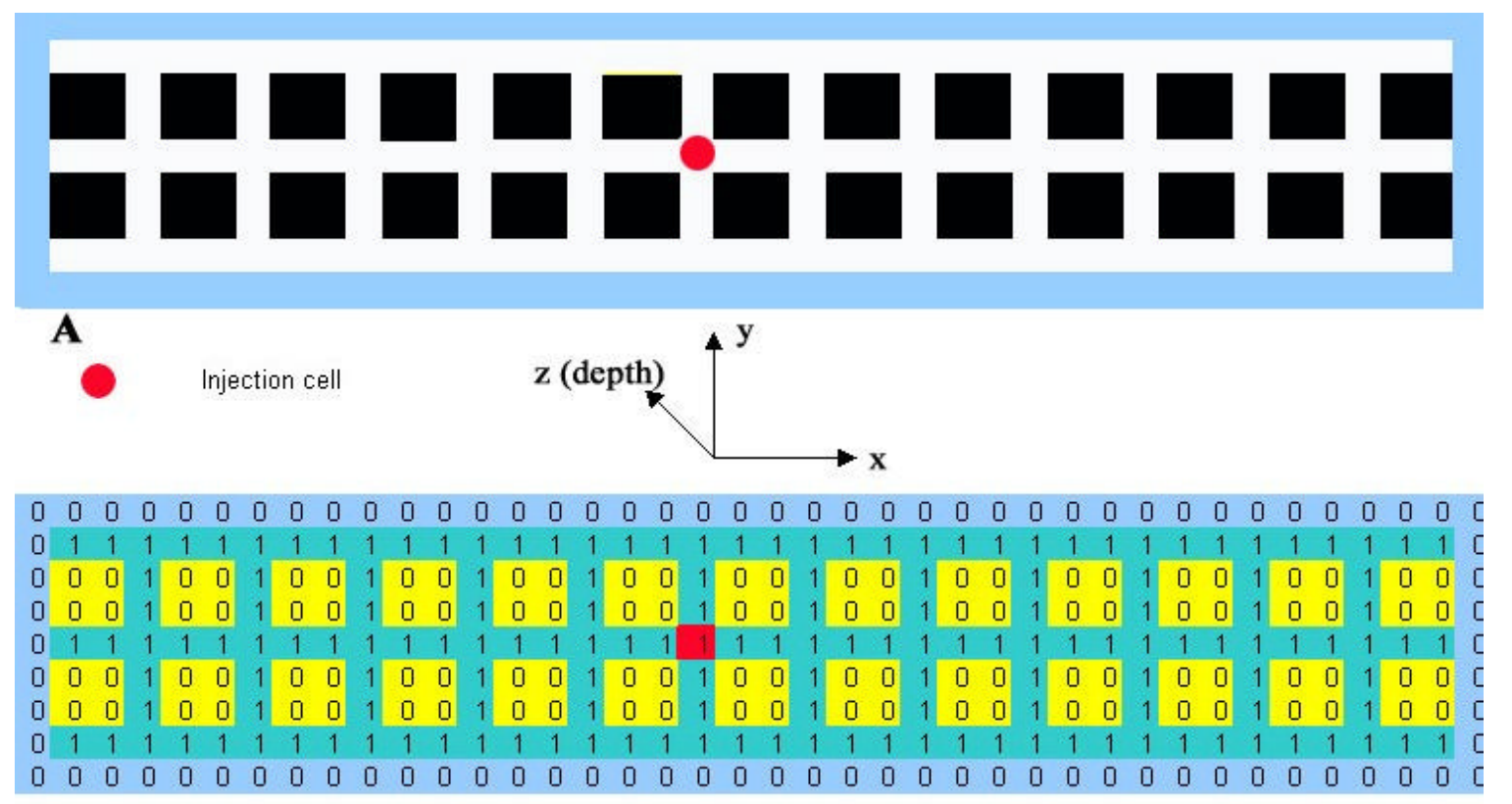

B

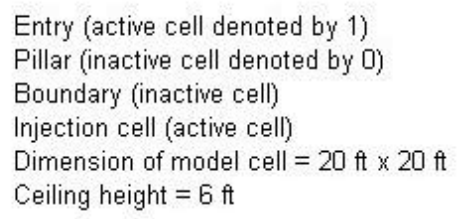

Figure 36. Physical channel (A) and its Groutnet equivalent model (B) for the three-entry system.

Table 17. Material properties of the injected grout.

\begin{tabular}{|l|l|l|}
\hline Modeling unit & Ft-lbs-s & SI \\
\hline Model cell size in both direction & $20 \mathrm{ft}$ & $6.096 \mathrm{~m}$ \\
\hline Total number of rows and column & 3,100 & 3,100 \\
\hline Number of active model cells & 99 & 99 \\
\hline Number of injection cells & 1 & 1 \\
\hline Maximum time step & $600 \mathrm{~s}$ & $600 \mathrm{~s}$ \\
\hline Minimum time step & $0.6 \mathrm{~s}$ & $0.6 \mathrm{~s}$ \\
\hline Computer used for calculation & Pentium II & Pentium II \\
\hline Total grout injection rate & $\begin{array}{l}120 \mathrm{t} / \mathrm{hr}, 150 \mathrm{t} / \mathrm{hr}, 200 \\
\text { t/hr }\end{array}$ & $\begin{array}{l}0.01716 \mathrm{~m}^{3} / \mathrm{s}, 0.02152 \\
\mathrm{~m}^{3} / \mathrm{s}, 0.0286 \mathrm{~m}^{3} / \mathrm{s}\end{array}$ \\
\hline Specific weight & $110 \mathrm{lbs} / \mathrm{ft}^{3}$ & $1762.101 \mathrm{~kg} / \mathrm{m}^{3}$ \\
\hline Yield stress & $1.04 \mathrm{lbs} / \mathrm{ft}^{2}$ & $50 \mathrm{~Pa}$ \\
\hline Grout hardening rate & $\begin{array}{l}\text { Non-hardening, } \\
\text { hardening }\end{array}$ & $\begin{array}{l}\text { Non-hardening, } \\
\text { hardening }\end{array}$ \\
\hline Plastic viscosity & $0.83 \mathrm{lbs}-\mathrm{s} / \mathrm{ft}^{2}$ & $40 \mathrm{~Pa}-\mathrm{s}$ \\
\hline Slope of the mine & $0 \%$ and $1 \%$ & $0 \%$ and $1 \%$ \\
\hline
\end{tabular}


Figure 37 AB shows the full-scale grout injection area of the Crown III mine and its Groutnet equivalent, respectively. To model this area in Groutnet, a total number of 25 rows and 58 columns were used, that is analysis was carried out for an area of $580 \mathrm{ft}$ long and $250 \mathrm{ft}$ wide. The dimension of a single cell was $10 \mathrm{ft} \times 10 \mathrm{ft}$, and a total number of 718 active model cells were used to model the above area realistically. In this model grout was injected for 10 hours a day followed by 14 hours of rest period. During this 14 hours of rest period, grout was allowed to harden. The slope of the area was $1.8 \%$ in the south-east (SE) direction, and was considered in the model. The injection points were located in two areas, marked by the red squares in Figure 37B. The properties of the grout material are listed in Table 17. Initially, grout was injected through the first borehole located at the left-hand side of the panel at the rate of 110 tons/hour. The aim of this study was to check how much grout could be injected through the first borehole and its flow profile. If the underground opening is not filled after the injection schedule through the first bore, further injection will be conducted through the second borehole, located at the right-hand side of the panel.
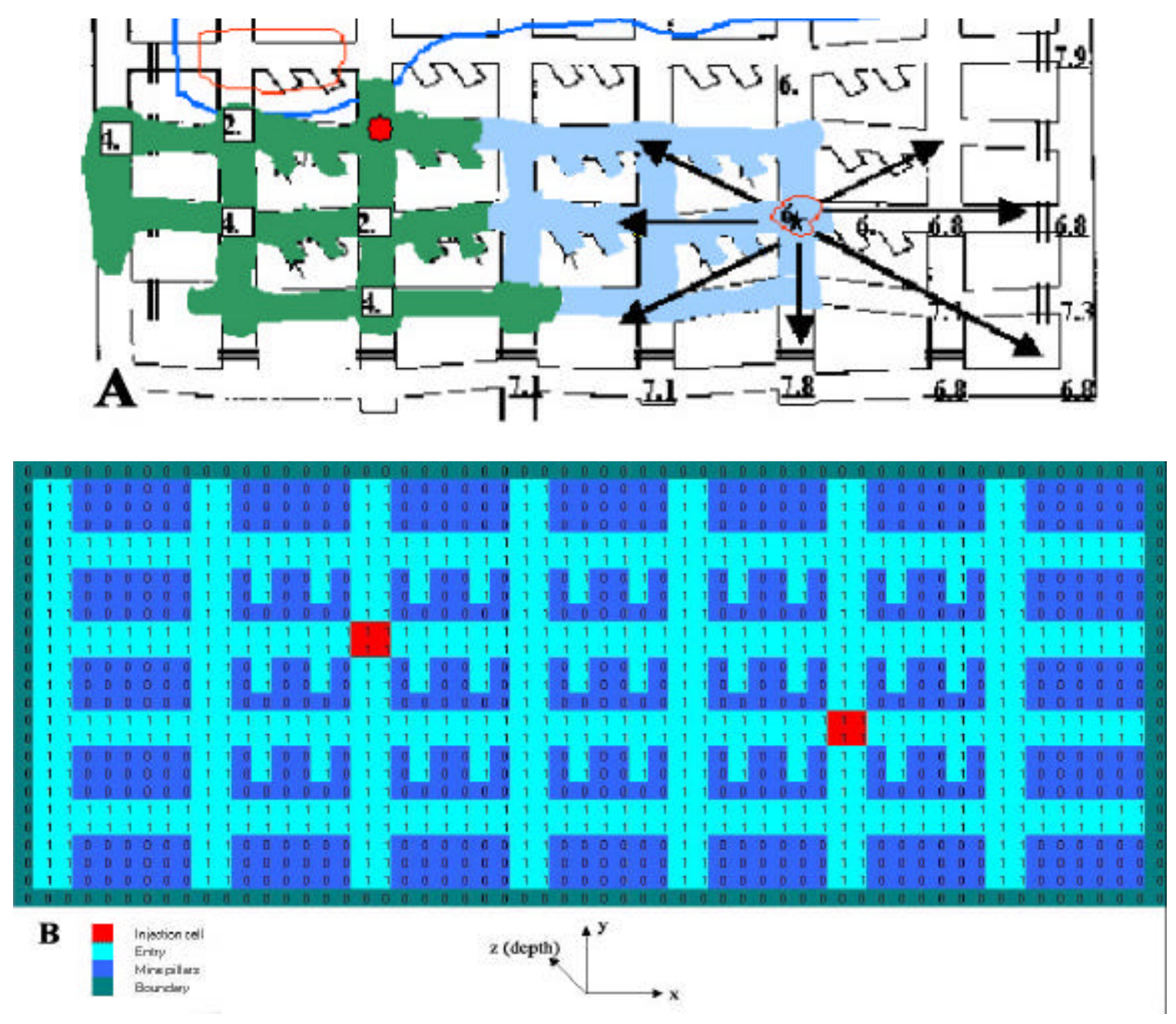

Figure 37. The Crown III room and pillar mine (A) and its Groutnet equivalent model (B) for grout flow analysis. 
Results and Discussion: The single entry simulations were conducted to investigate the effect of 1) slope, 2) hardening rate, 3) pumping rate and 4) yield stress. Previous investigation by other researchers and the authors indicated that by reducing both yield stress and plastic viscosity, the flowability of the material can be improved (reports already submitted), and hence they have not been incorporated in this report. The simulations of the single entry system were conducted to calibrate the Groutnet program and its accuracy. The knowledge gained from the single entry system was then further applied to a three-entry system to further calibrate the program. Finally, the full-scale underground mine was simulated. The results of all the simulations are presented in the following sections.

\section{A. Single Entry Analysis Results}

Calibration of the Model: The simulation was allowed to proceed until the entire channel was filled with grout. After the model cell near the injection area was filled, the injected grout flowed under pressure. Figure 38 shows the spread of grout profile at different time periods, the total time taken to fill the complete channel was 5 days 13 hours 52 minutes and 8 seconds and the amount of grout material used was 14,430 tons. According to the injection rate, the channel should have been filled with grout after 4 days 12 hours 52 minutes and 36 seconds. However, Groutnet took 5 days 13 hours 52 minutes and 8 seconds to fill the complete channel. The discrepancy is due to the volume error of $23 \%$ of the actual volume. The volume error was not consistent in different simulations. It varied from $1 \%$ to about $18 \%$ in different simulations. Keeping this in mind, further simulations were carried out.

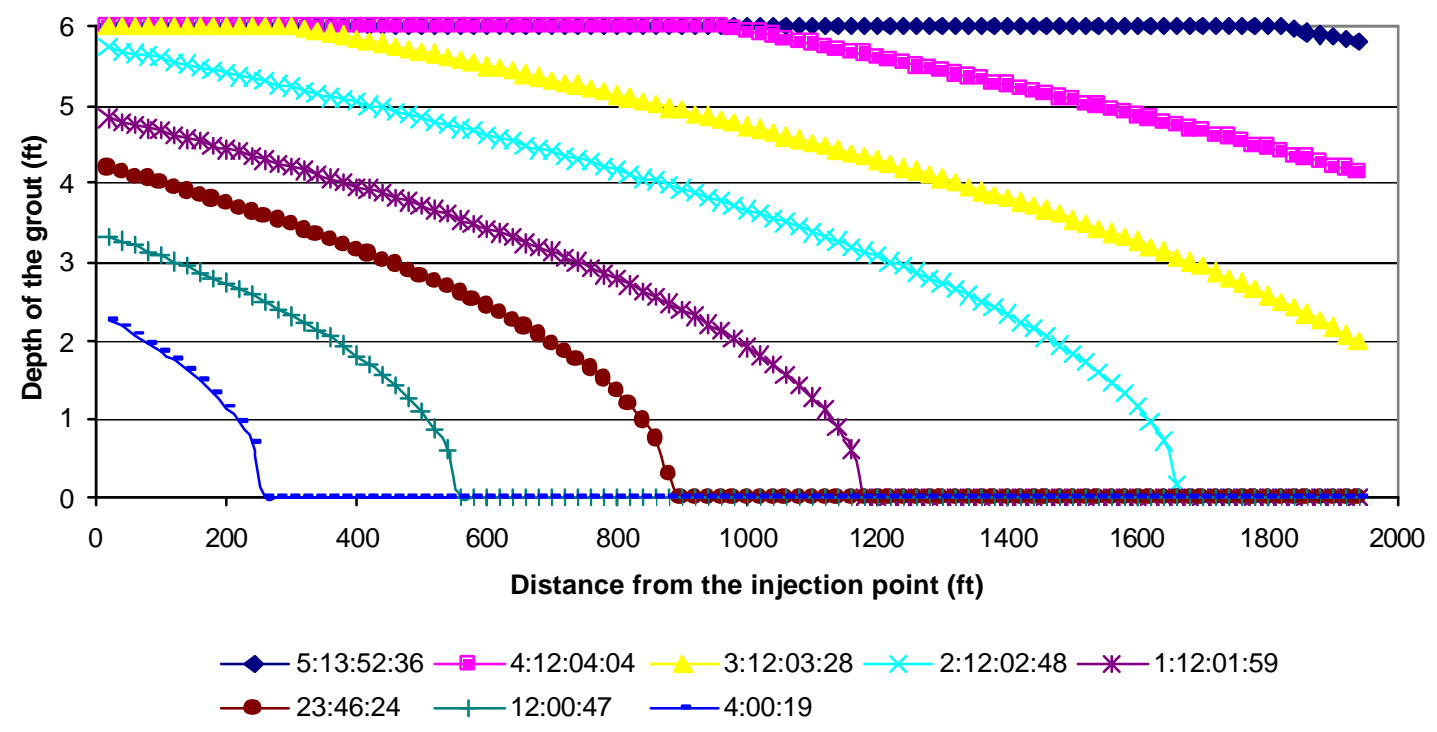

Figure 38. Grout profile of $5 \frac{1}{2}$ days of grout injection at $0 \%$ slope. 
Effect of Channel Floor Slope: The floors of underground mines typically follow the slope (dip) of the coal seam, and are usually not level. The dip can be more than $10 \%$. Under uniform, laminar and open channel flow conditions, the slope of the energy grade line is equal to the slope of the channel. In such a situation, the velocity of the flow is directly proportional to the slope. To investigate the effect of the channel slope on the spread of grout, a parametric study of channel slope was carried out.

Figure 38 and 39, respectively compare the effect of $0 \%$ and $1 \%$ slope of the channel floor after about $5 \frac{1}{2}$ days of grout injection. Figure 39 shows that with $1 \%$ channel floor slope, the flow behavior is normal up to about 12 hours of grout injection. No oscillation was recorded during this period. During this time, the grout flows up to about $1200 \mathrm{ft}$. This deposition of grout on the channel floor raises the slope such that grout starts to fill up at the extreme right end of the channel slope, and then approaches the left-hand side of the channel (Figure 39).

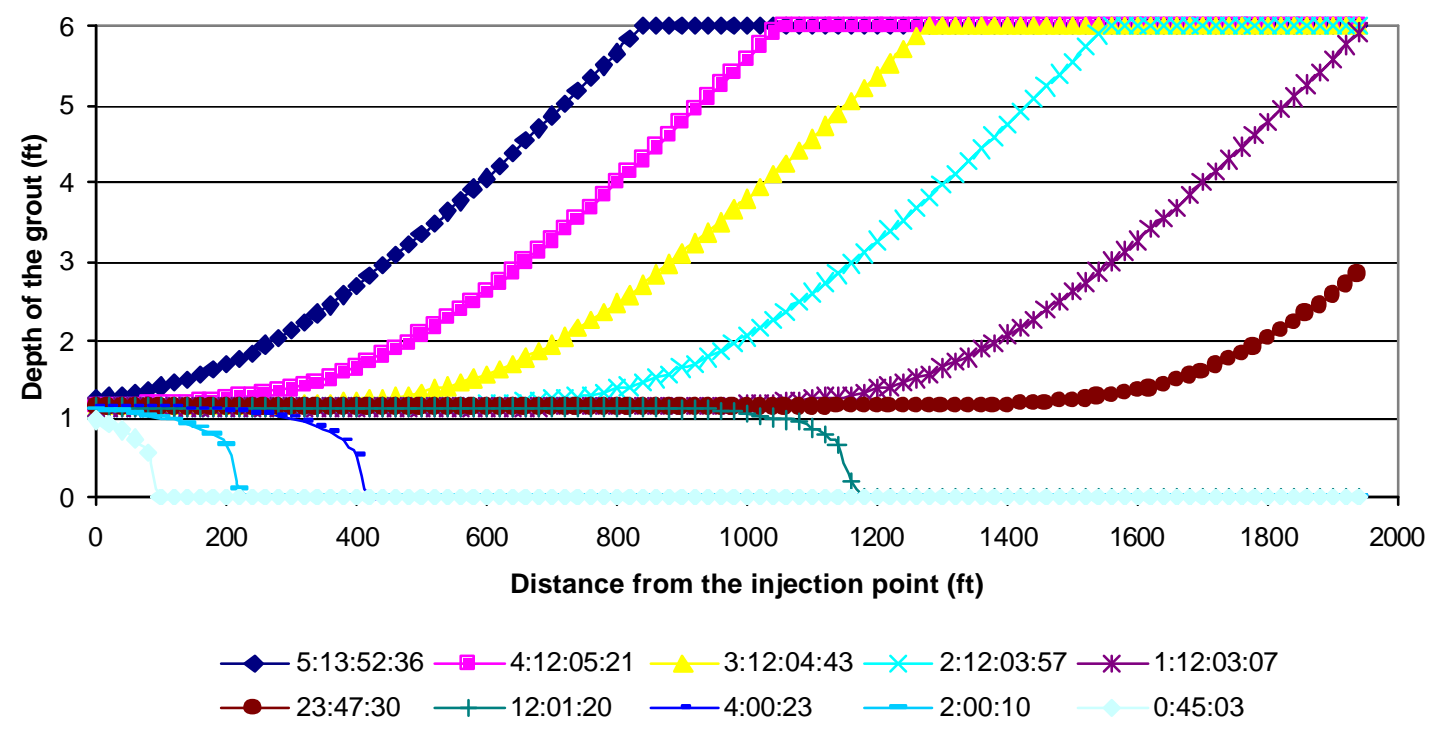

Figure 39. Grout profile after $5 \frac{1}{2} 2$ days of grout injection at $1 \%$ slope.

The amount of material used for $1 \%$ channel slope was 14, 430 ton, which is the same as if it were a $0 \%$ slope. The amount of time required to fill the channel for $1 \%$ slope is also approximately same as $0 \%$ slope. However for $1 \%$ slope, theoretically, the channel should have been filled with less material in a less time than $0 \%$ slope. This cannot be explained at this time.

Effect of Pumping Rate: Figures 40, 41 and 42 show the effect of the pumping rate at 120 ton/hour, 150 ton/hour and 200 ton/hour, respectively. Figure 40 shows that when the pumping rate is 120 ton/hour, it takes about 5 days 13 hours 52 minutes and 8 seconds to fill the channel. Further increasing the pumping rate to about 150 ton/hour, it takes about 4 days 12 hour 35 minutes and 8 seconds. By further increasing the pumping rate to 200 ton/hour, it takes 3 days 6 hours 11 minutes and 33 seconds. 


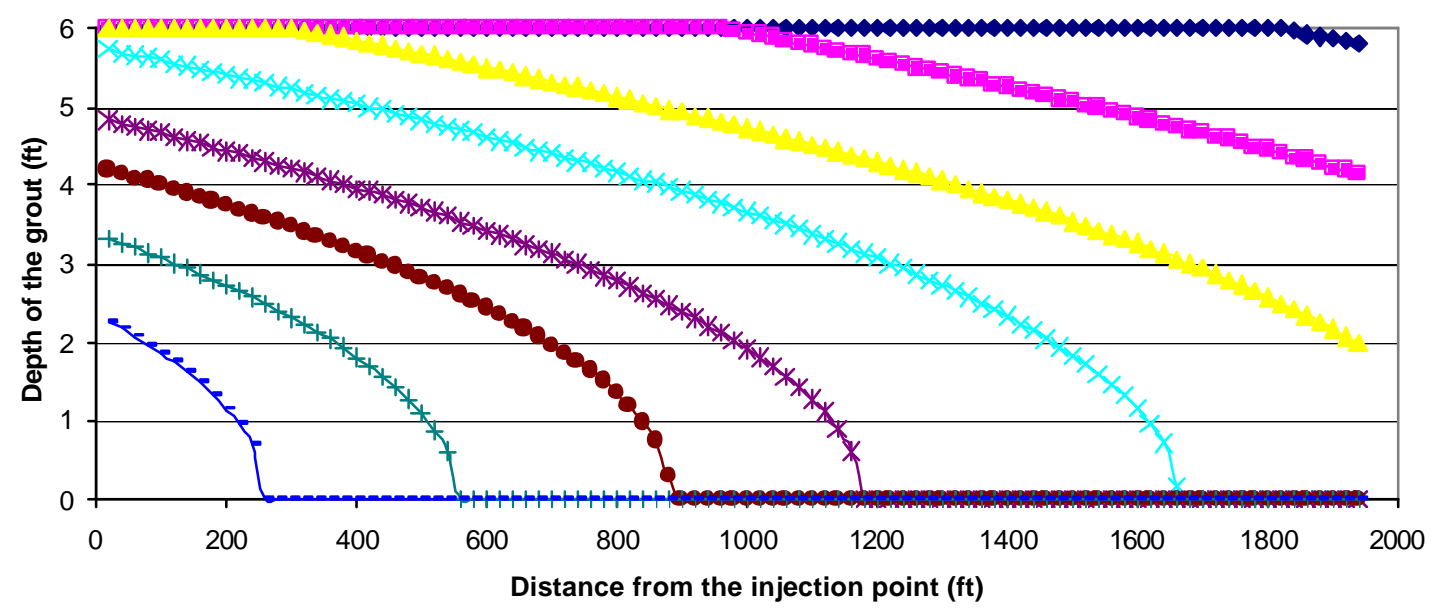

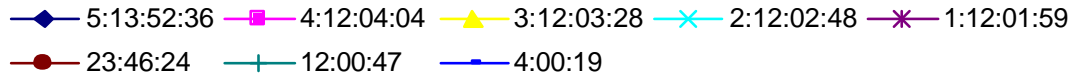

Figure 40. Grout profile of 5 1/2 days of grout injection at 120 tons/hour pumping rate $\left(0.0176 \mathrm{~m}^{3} / \mathrm{s}\right)$.

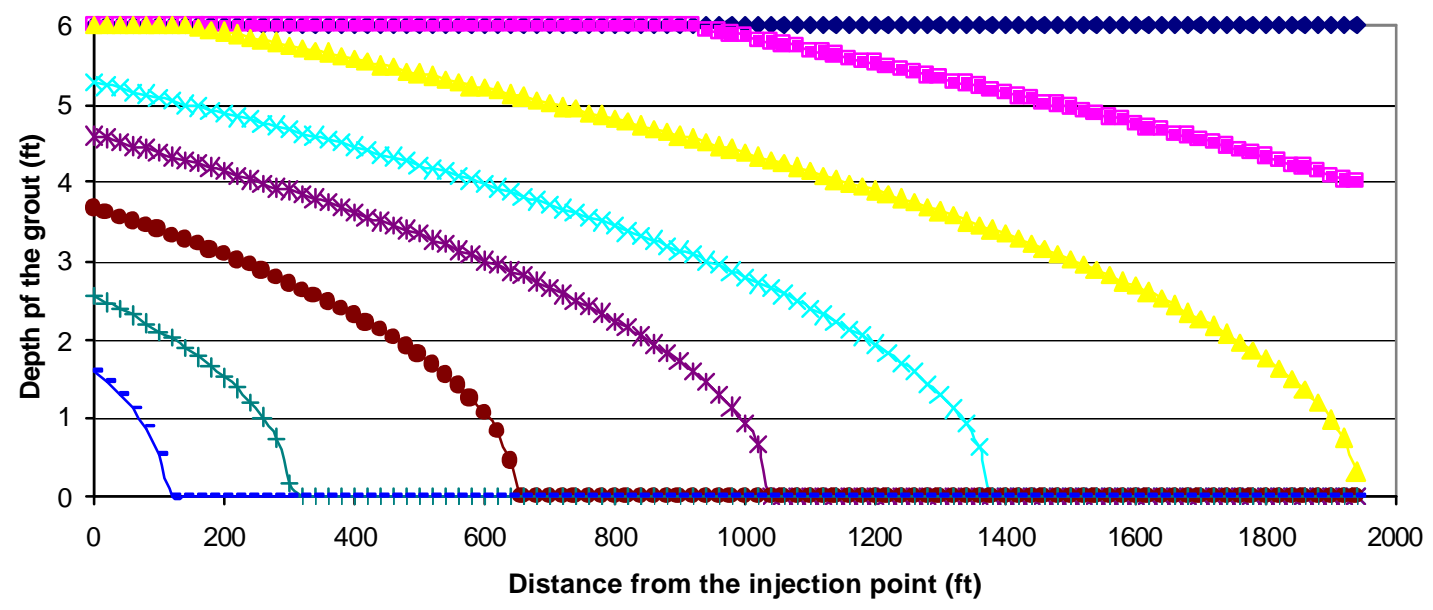

Figure 41 . Grout profile of $5 \frac{1}{2}$ days of grout injection at 150 tons/hour pumping rate $\left(0.02152 \mathrm{~m}^{3} / \mathrm{s}\right)$. 


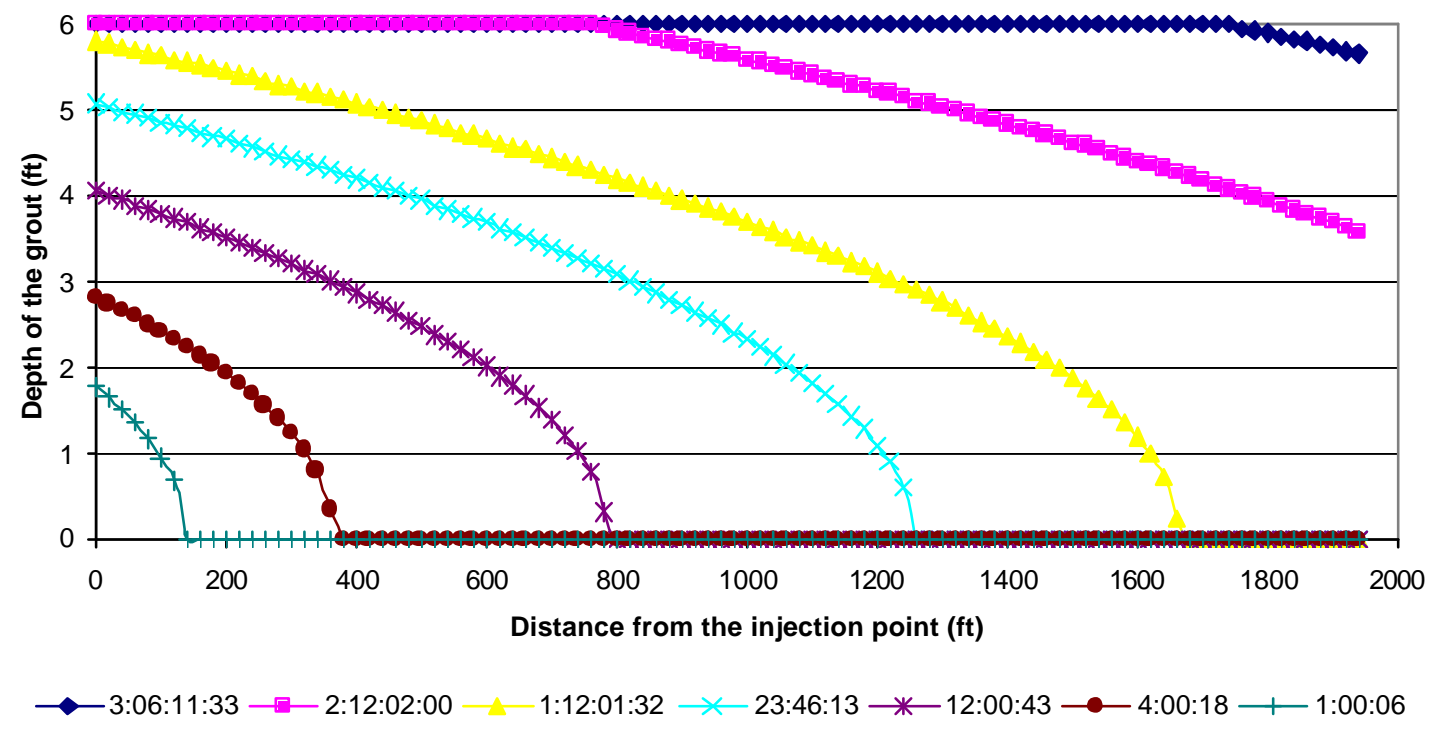

Figure 42. Grout profile of 5 1/2 days of grout injection at 200 tons/hour pumping rate $\left(0.0286 \mathrm{~m}^{3} / \mathrm{s}\right)$.

The amount of grout material pumped and the flow distance at different pumping rate were also studied, and are shown in Figures 43 and 44, respectively. Figure 43 shows that if pumping rate increases, the amount of grout required to fill the channel becomes more only up to a certain pumping rate (160 tons/hour). After this, the amount of material required to fill the channel is reduced. This may be due to choking of the grout at the injection point.

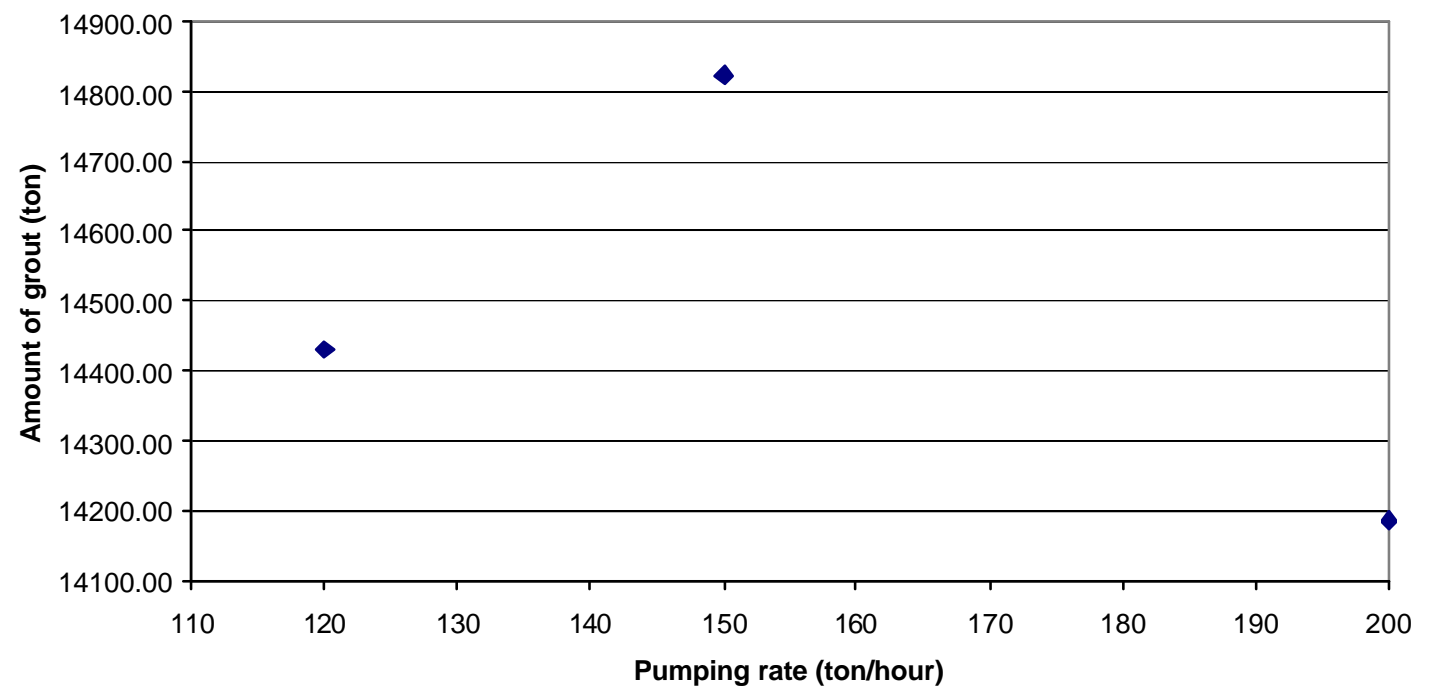

Figure 43. Amount of grout used vs. rate of pumping. 
Figure 44 shows the pumping rate vs. the distance traveled by the grout at the end of $1 \frac{1 / 2}{2}$ days. The result shows that if pumping rate increases, the distance traveled by the grout also increases.

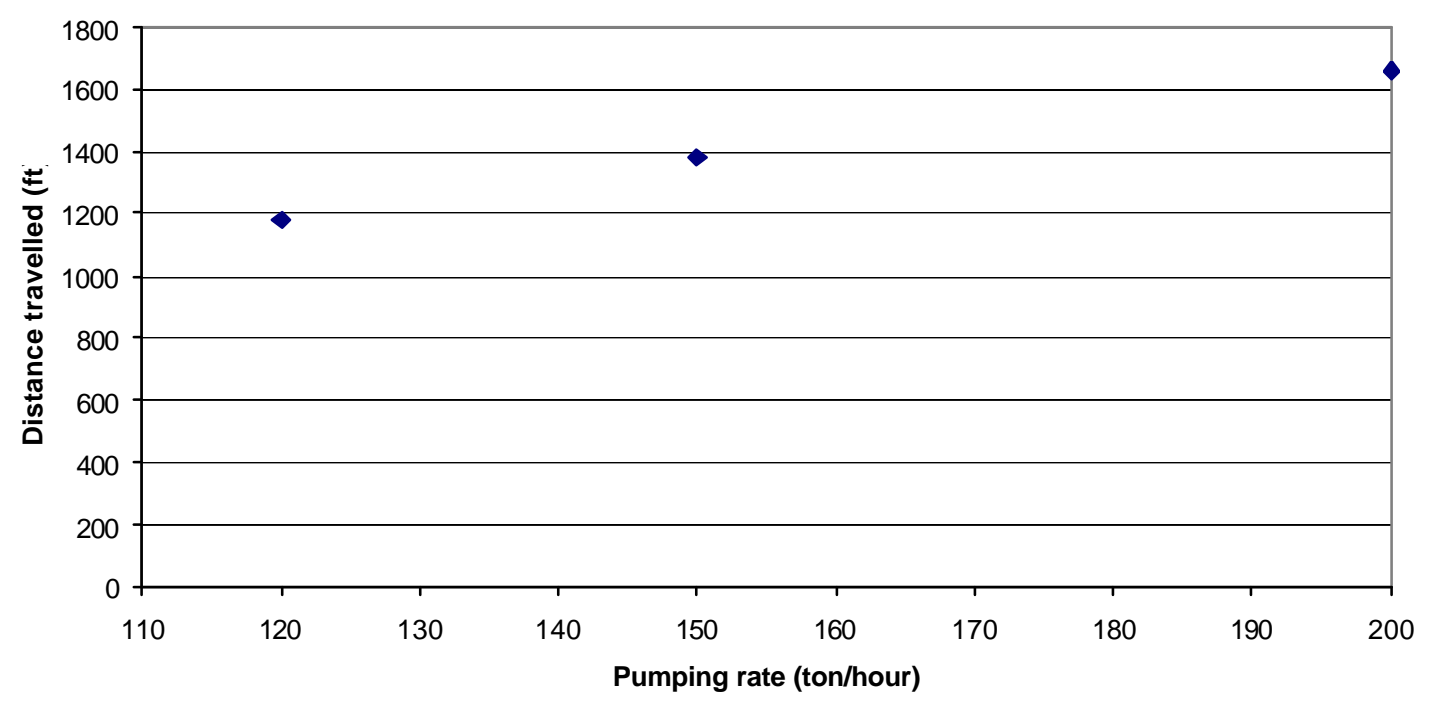

Figure 44. Amount of grout used vs. traveled distance of the grout.

Effect of Grout Hardening: In Groutnet, the simulation of grout hardening can be accomplished two different ways, namely 1) by allowing the injected grout to harden completely after each injection period, and 2) using marker particles in the injected grout to calculate the age of the injected grout. The age of the injected grout is used to calculate the yield stress of the grout material at any given point of time. In the present simulation, the second method was used. The model parameters and their values are listed in Table 17.

In the simulation it was assumed that the injected grout would harden after four (4) days of injection. From the literature, it was found that the yield stress at the beginning of the second day's injection is $100 \mathrm{~Pa}$ (Stiles, 1999). Therefore, the ultimate yield stress was considered to be $400 \mathrm{~Pa}$ in the simulation.

Figure 45 shows the simulation result (grout profile) of the grout hardening process. Figure 45 shows that at the end of 3 days 23 hours 48 minutes and 47 seconds, grout hardens up to a distance of $680 \mathrm{ft}$ from the injection point, and the openings in this area are completely filled. Therefore, no further grout injection could be done at the end of approximately four days. However, further injection, in such a situation, will require pressure to be applied to the hardened grout. 


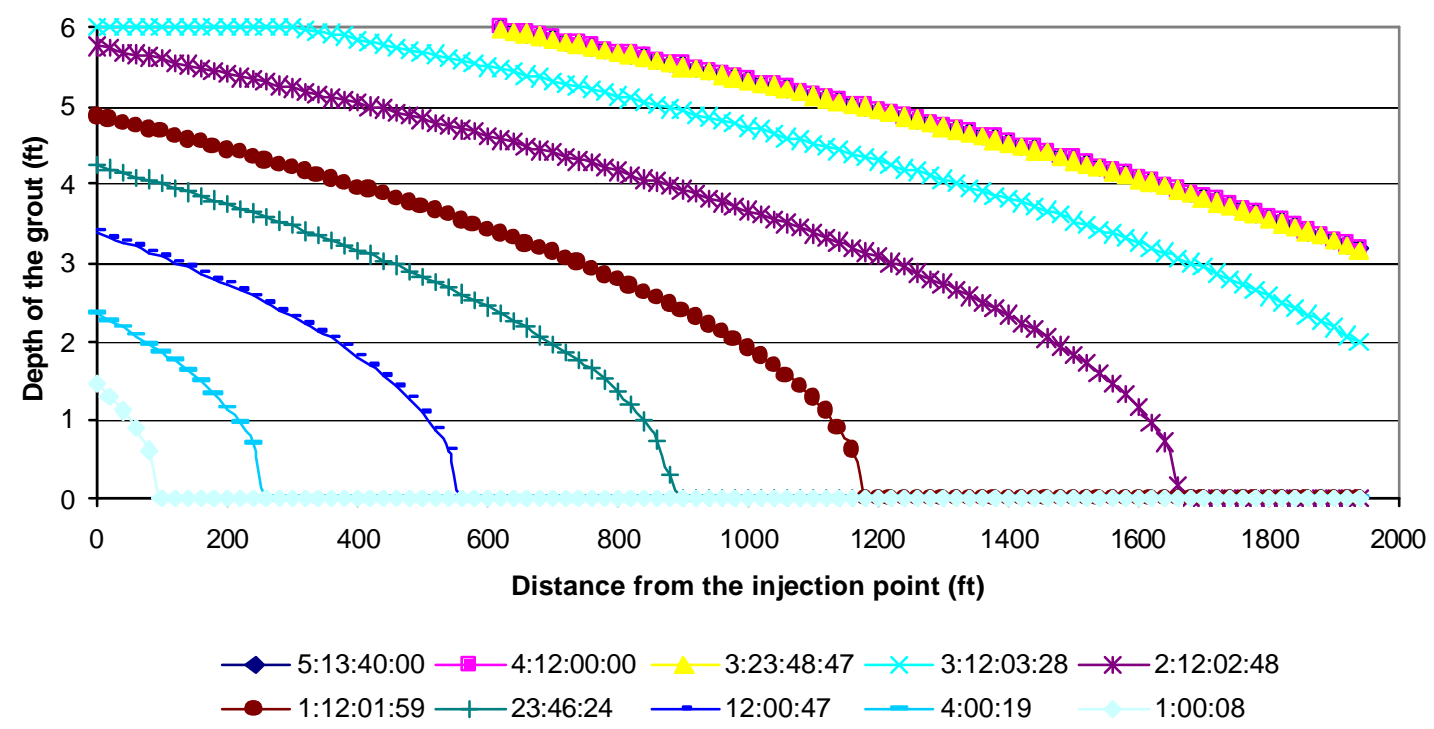

Figure 45. Grout profile for the grout hardening (the grout starts hardening at the end of third day).

\section{B. Three Entry Analysis Results}

Figures 46 through 48 show the results of the three-entry analysis at different time intervals. Figure 46 shows that the average depth of the grout after 12 hours of injection is $1.38 \mathrm{ft}$. Figure 47 shows the flood map of the spread of grout after 1 day 15 hours 2 minute and 50 seconds of injection. The average depth of grout after this time period varied from $0.32 \mathrm{ft}$ to $2.5 \mathrm{ft}$.

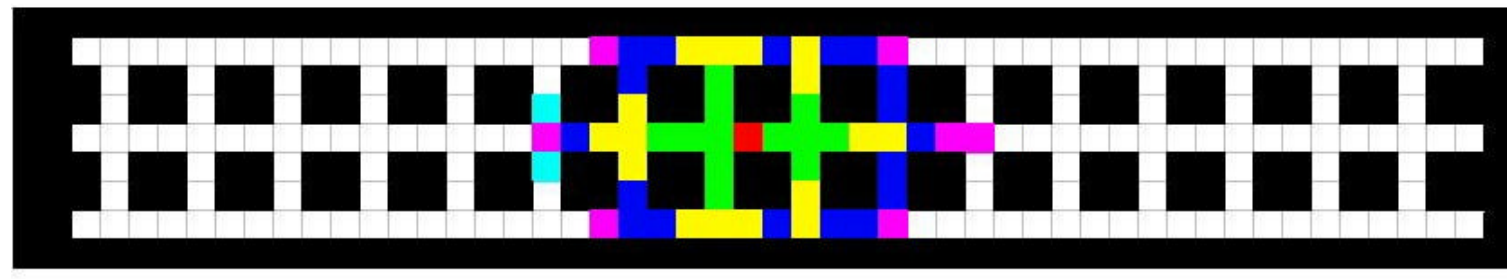
$0.79 \mathrm{ft}$
$1.76 \mathrm{ft}$
$0.47 \mathrm{ft}$
$1.87 \mathrm{ft}$
$0.83 \mathrm{ft}$
$6.00 \mathrm{ft}$
$1.38 \mathrm{ft}$

Figure 46. Flood map of grout profile after 12 hours and 1 minute of grout injection. 


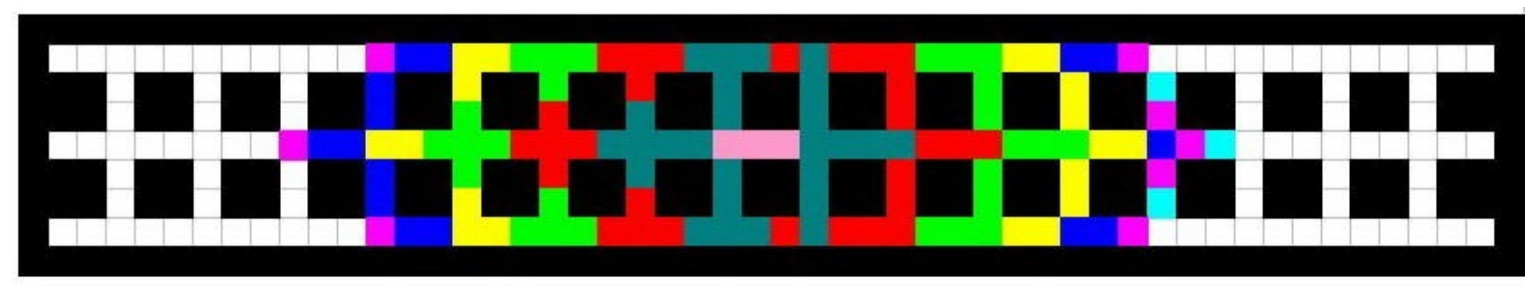
$2.50 \mathrm{ft}$
$0.82-1.14 \mathrm{ft}$
$2.16 \mathrm{ft}$
$0.49-0.82 \mathrm{ft}$
$1.80-2.13 \mathrm{ft}$
$0.32-0.49 \mathrm{ft}$
$1.47-1.80 \mathrm{ft}$
$6.00 \mathrm{ft}$
$1.14-1.47 \mathrm{ft}$

Figure 47. Flood map of grout profile after 1 day 15 hours 2 minutes and 15 seconds of grout injection.

Figure 48 shows the flood map at the end of 10 days 18 hours and 12 minutes (assuming 1 day $=24$ hours for continuous injection) for the three-entry system. The simulation stopped at 10:18:12:24 days. According to the rate of injection, the three-entry system should have been filled after 9 days 21 hours 45 minutes and 5 seconds. The amount of grout used was 27832.39 tonne $\left(15795.00 \mathrm{~m}^{3}\right)$. Theoretically, the amount of grout required to fill the complete three-entry roadway $\left(14543.53 \mathrm{~m}^{3}\right)$ is 25627.17 ton. Therefore, there is a volume error of approximately $8 \%$ associated with the simulation. This volume error is due to the finite difference approximation of the Groutnet procedure.

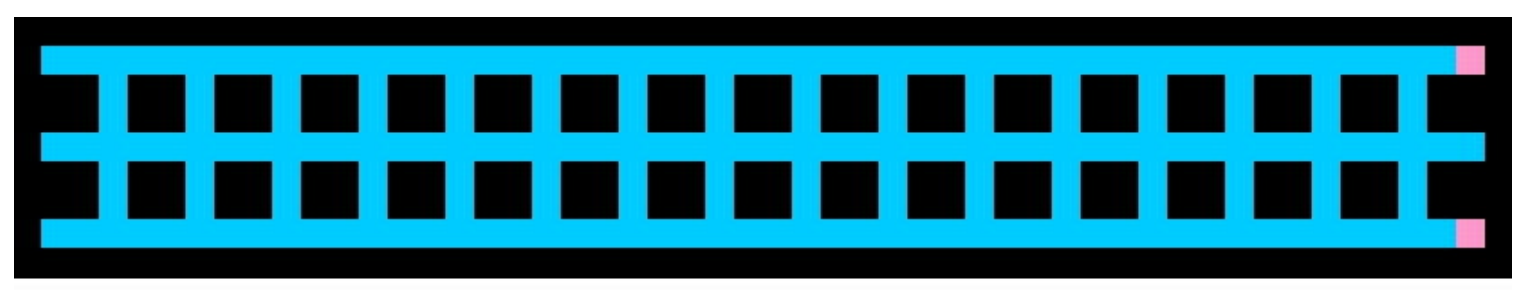

$6 \mathrm{ft}$

$5.99 \mathrm{ft}$

Figure 48. Flood map of grout profile after 10 days 18 hours 12 minutes and 24 seconds of grout injection.

\section{Crown III Mine Analysis Results}

Figures 49 through 57 show the results of the Crown III mine simulation after 1, 2, 3, 4, 5, 6, 7 and 10 days, respectively. After one day of grout injection, the grout spread up to $220 \mathrm{ft}$ from the injection point in the horizontal dip direction and $80 \mathrm{ft}$ in the horizontal rise direction. Along the rise direction, it spread up to $100 \mathrm{ft}$. The maximum depth of grout was near the injection point and was about $2.51 \mathrm{ft}$ (Figure 49). The amount of grout pumped after one hour was 1100.06 tons. 


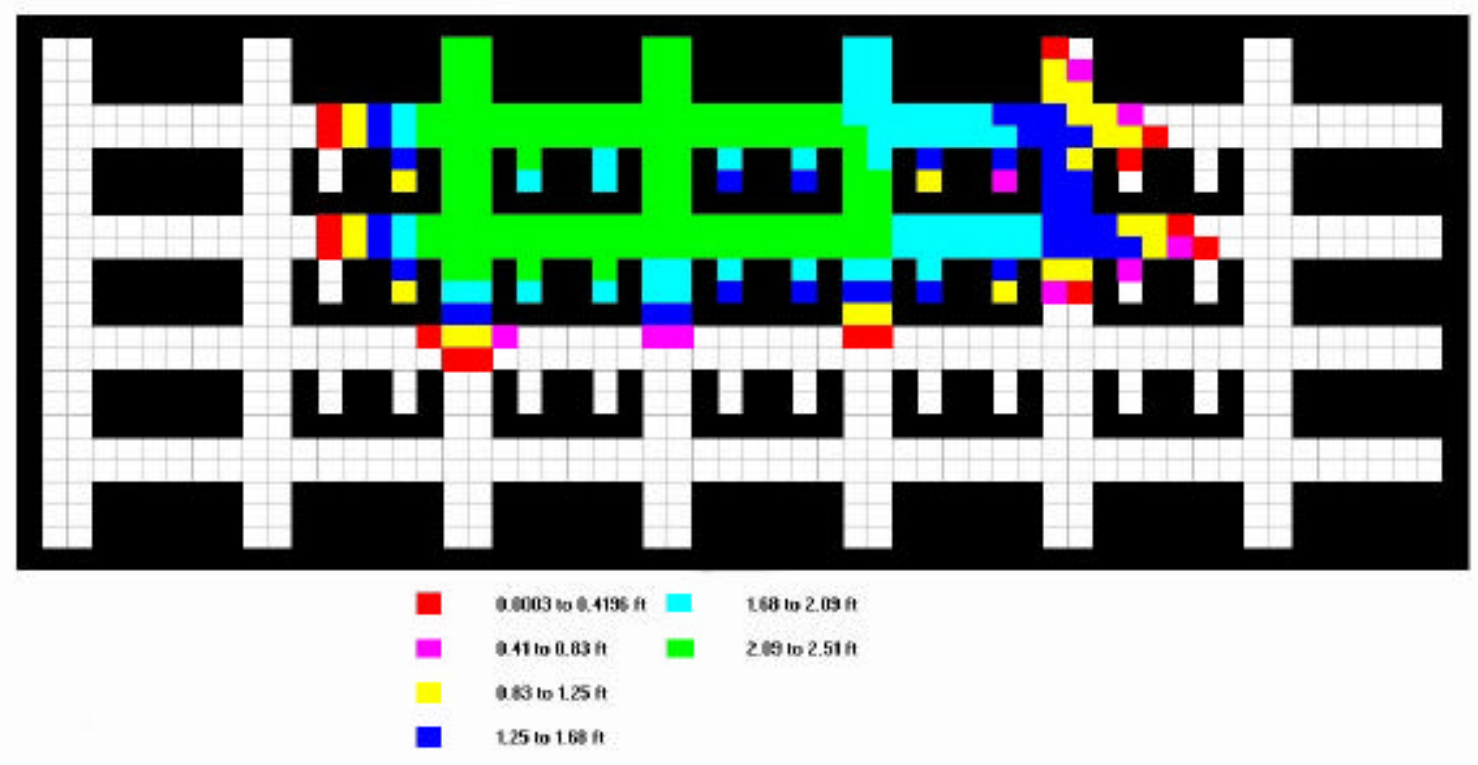

Figure 49. Flood map of grout profile after 1 day of grout injection.

After two days grout flowed further from the injection point in all the directions. In the horizontal direction, it spread maximum of $300 \mathrm{ft}$ in the horizontal direction, and $100 \mathrm{ft}$ in the vertical direction from the injection point. In the rise direction, the maximum depth of grout was about $3.75 \mathrm{ft}$. The amount of grout used after two days was about 2199.98 tons (Figure 50).

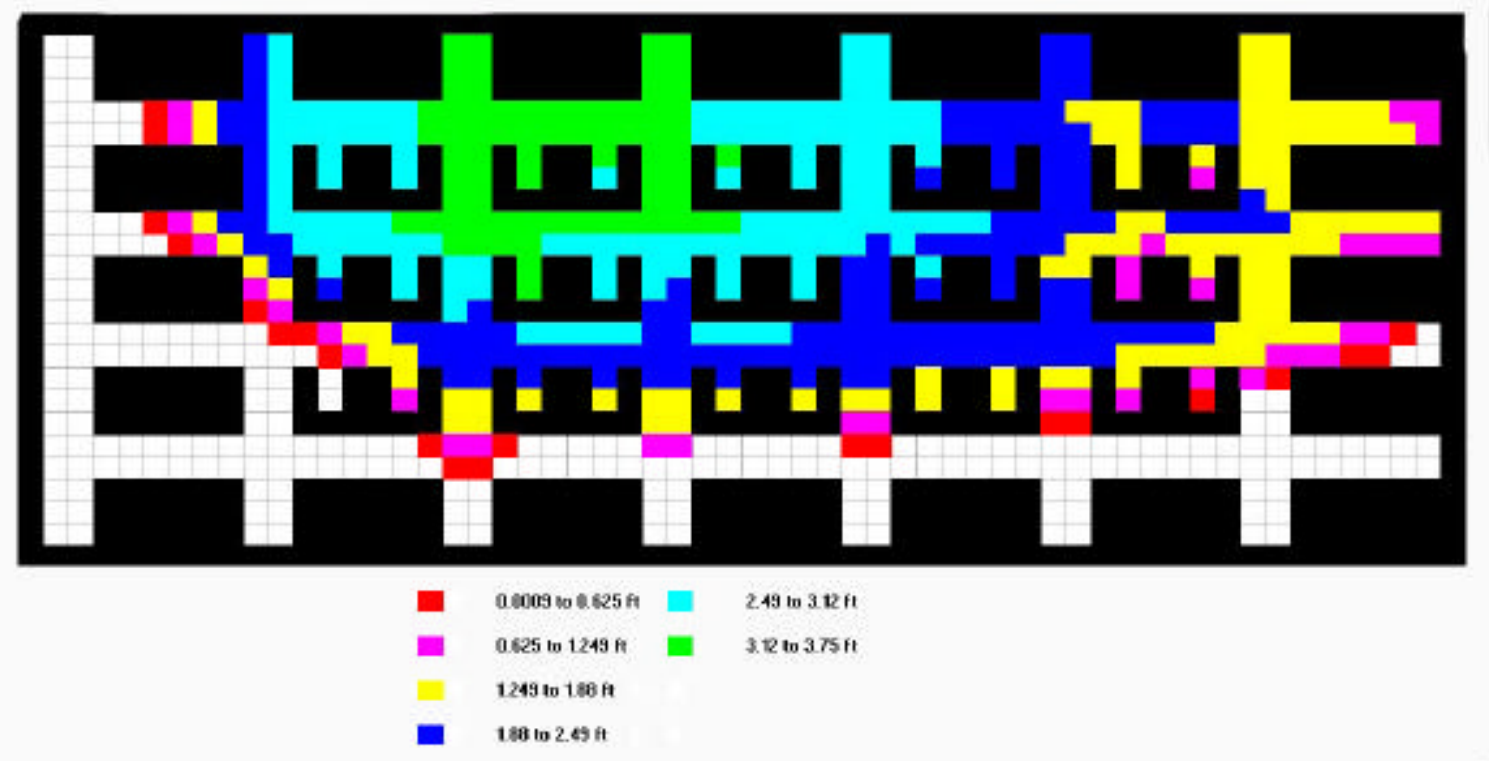

Figure 50. Flood map of grout profile after 2 days of grout injection.

After three days of grout injection, grout flowed in almost all the areas, except some places in the dip side. The maximum grout was accumulated in the North-East direction 
in the dip side. The maximum depth of grout near the injection point was from 4.13 to $4.96 \mathrm{ft}$. The amount of material used after three days was about 3300 tons (Figure 51).

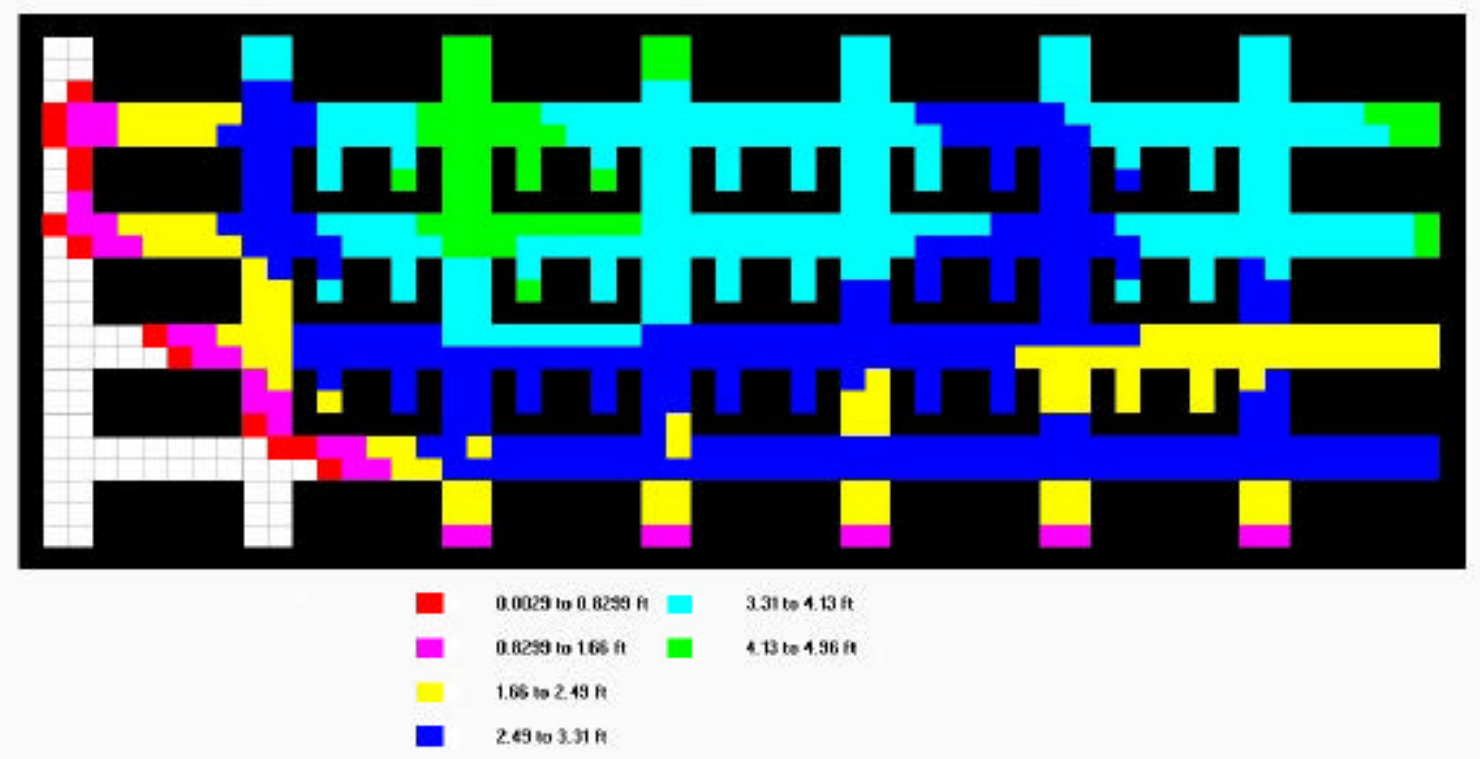

Figure 51. Flood map of grout profile after 3 days of grout injection.

After four days of grout injection, grout flowed in almost all the areas, except some places in the rise side. The maximum grout was accumulated near the injection point. The maximum depth of grout near the injection point was from 5.01 to $6 \mathrm{ft}$. The amount of material used after four days was about 4400 tons (Figure 52).

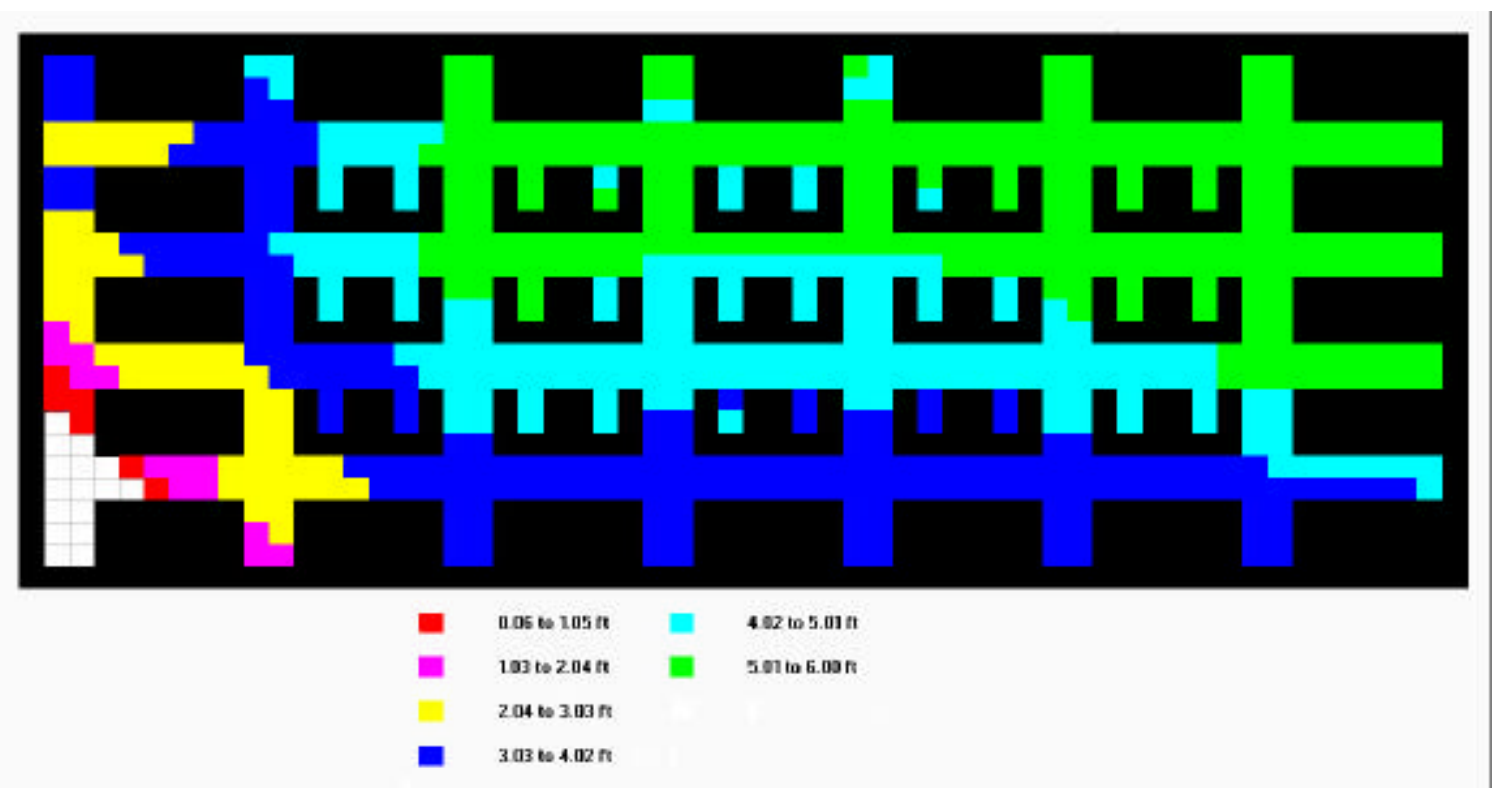

Figure 52. Flood map of grout profile after 4 days of grout injection. 
After five days of grout injection, grout flowed in all the areas, and the mine was filled to about $90 \%$ of the areas. The maximum grout (5.3ft to $6 \mathrm{ft}$ in depth) was accumulated near the right side of the injection point. The maximum depth of grout near the left side of the injection point was from 3.91 to $5.30 \mathrm{ft}$. The amount of material used after five days was about 5500 tons (Figure 53).

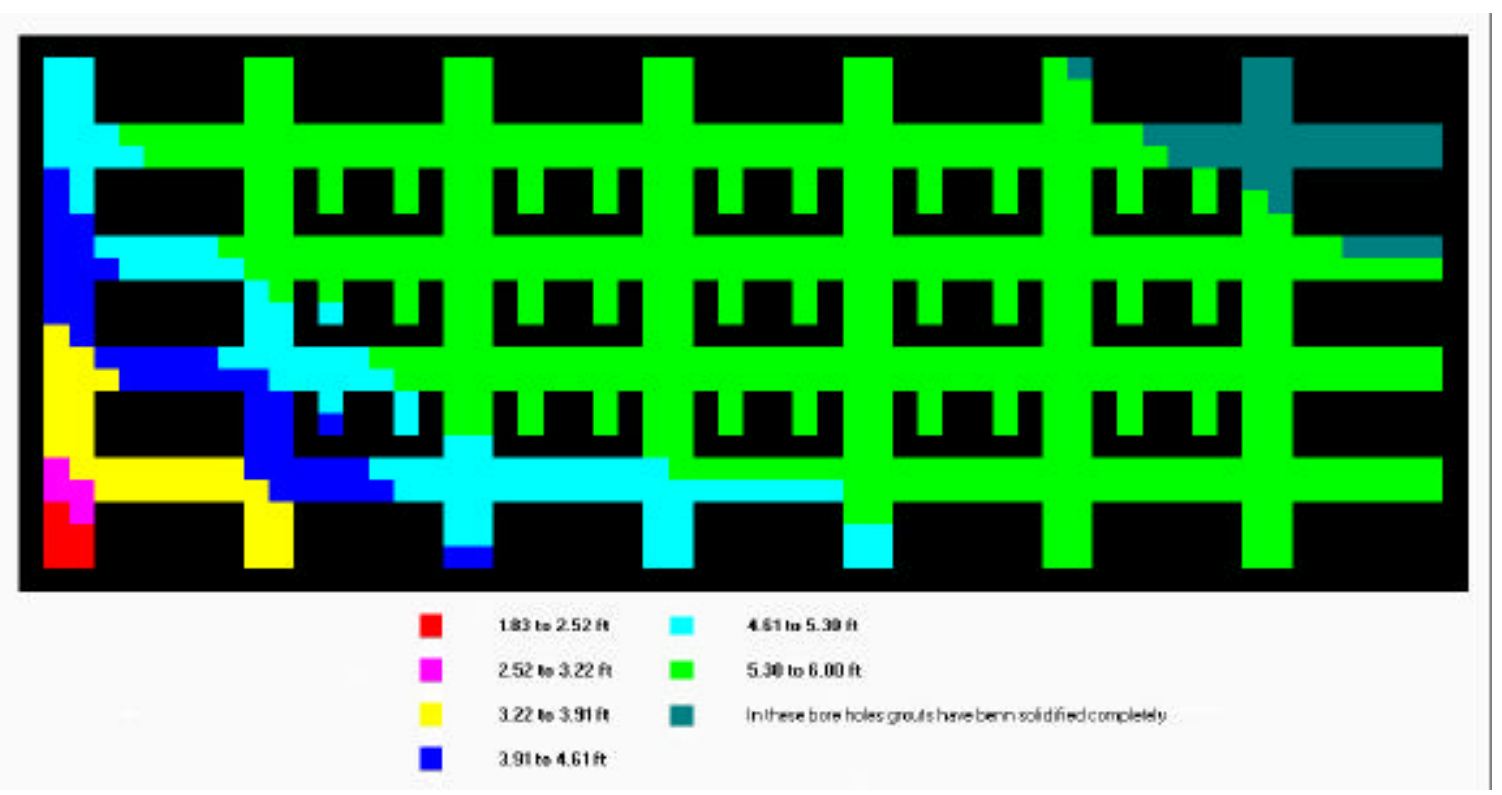

Figure 53. Flood map of grout profile after 5 days of grout injection.

After six days of grout injection, grout flowed in all the areas, and in about $90 \%$ of the areas, all the grouts were filled and solidified. No further flow occurred in these areas as well as the injection. However, there was some amount of $\mathrm{bw}$ in the left side of the injection point in the dip side. The maximum depth of grout in these areas was also very high (5.52 ft to $6 \mathrm{ft}$ in depth). The amount of material used after six days was about 6600 tons (Figure 54). 


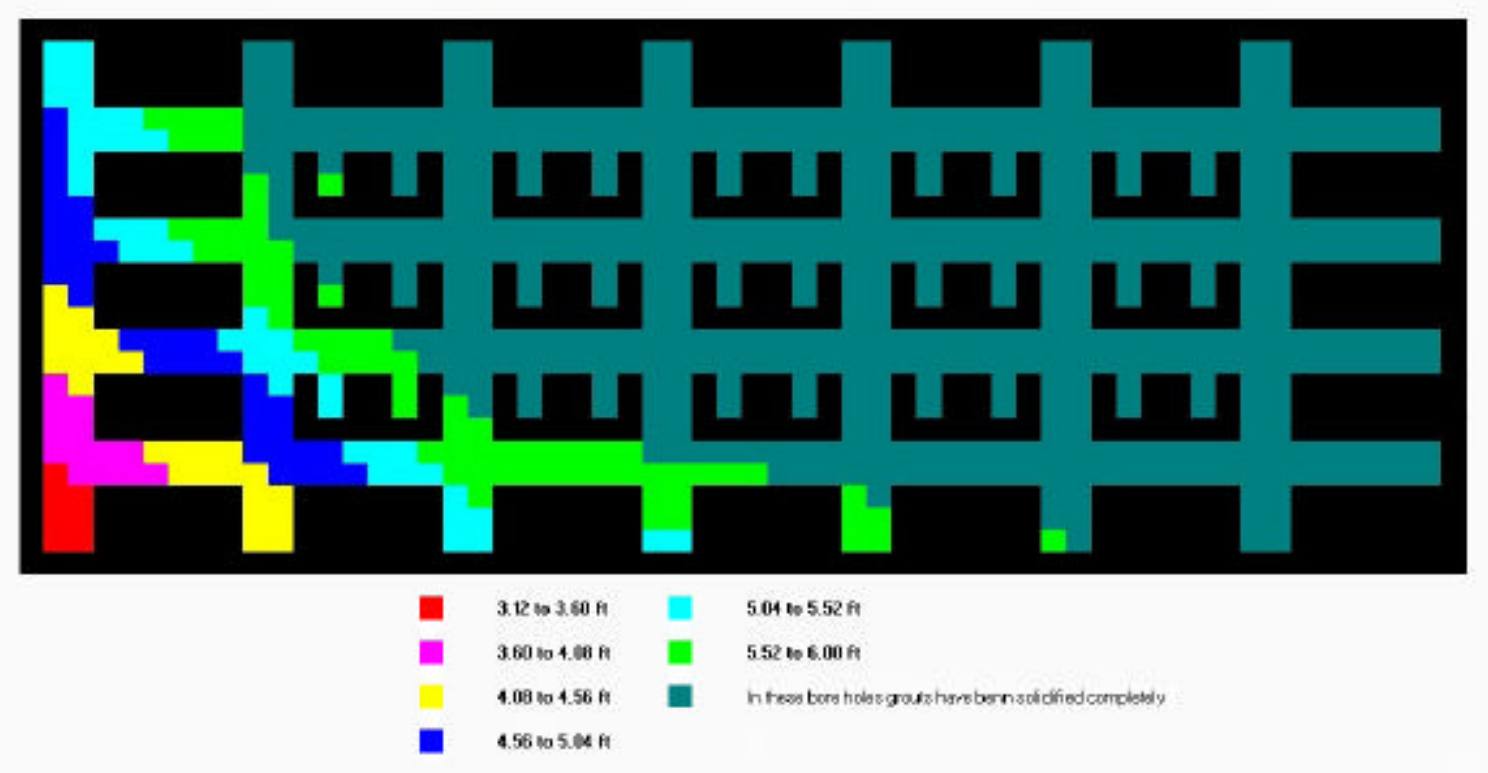

Figure 54. Flood map of grout profile after 6 days of grout injection.

As the flow continued, the profile obtained after 7 days of the grout injection was not significantly different than day 6 (Figure 55). The amount of material used at the beginning of the $7^{\text {th }}$ day was 6601 tons. No further was done after end of the end of 6 days, nd the grout was was not solidified flowed internally. That is why profile obtained after the $6^{\text {th }}$ and $7^{\text {th }}$ days are almost identical.

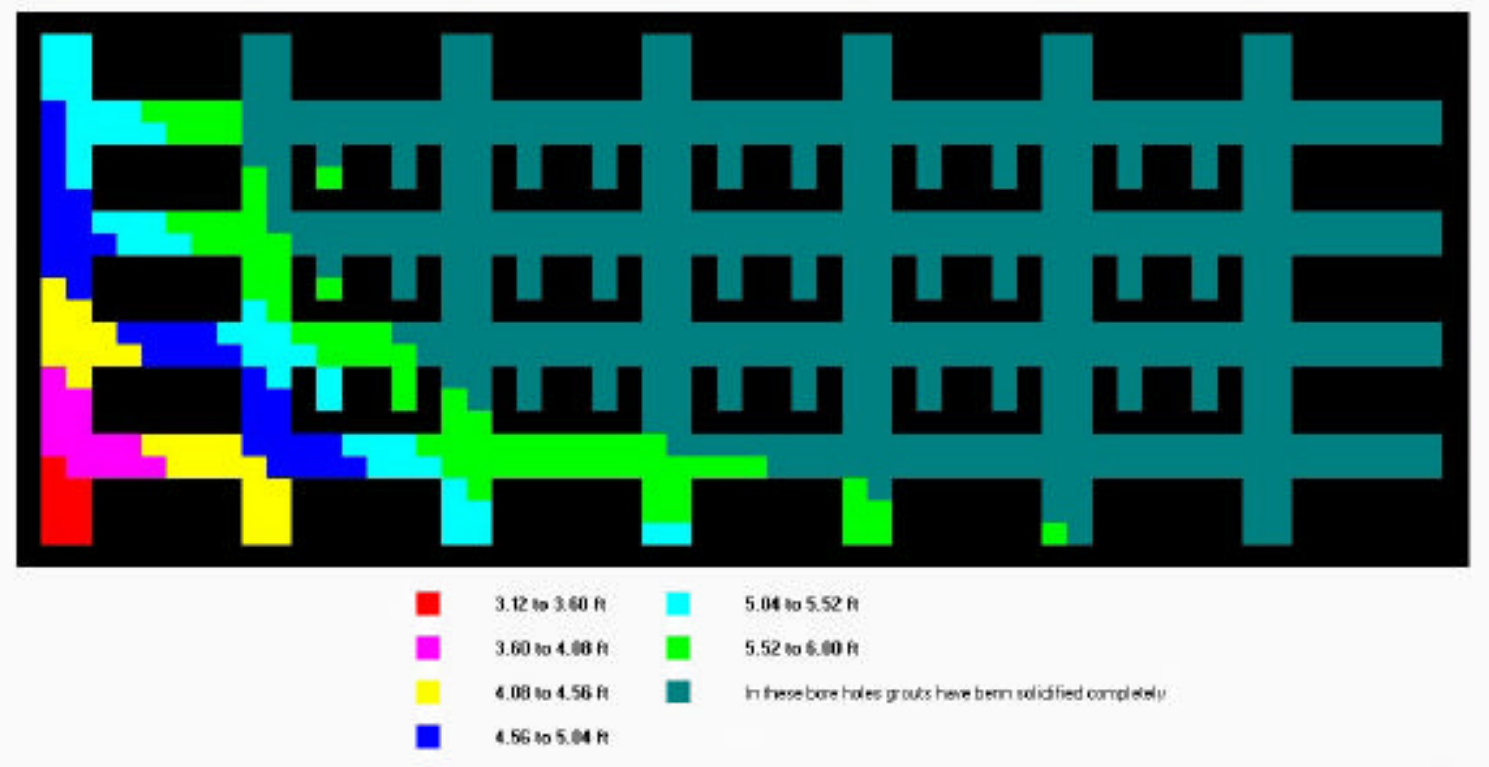

Figure 55. Flood map of grout profile after 7 days of grout injection. 
The simulation still continued because of the very little internal flow of grout and ended on day 10. At this point the most of the underground voids were filled with solidified grout. The maximum depth after the end of $10^{\text {th }}$ day was 5.52 to $6 \mathrm{ft}$ (Figure 56).

The most of the grout flowed in the dip direction first. This is obvious for the sloping mine floor, and the same behavior was observed in one entry slope analysis. The total tonnage used after the end of ten days was approximately 6605 tons (Figure 56). This coincides well with the calculated tonnage.

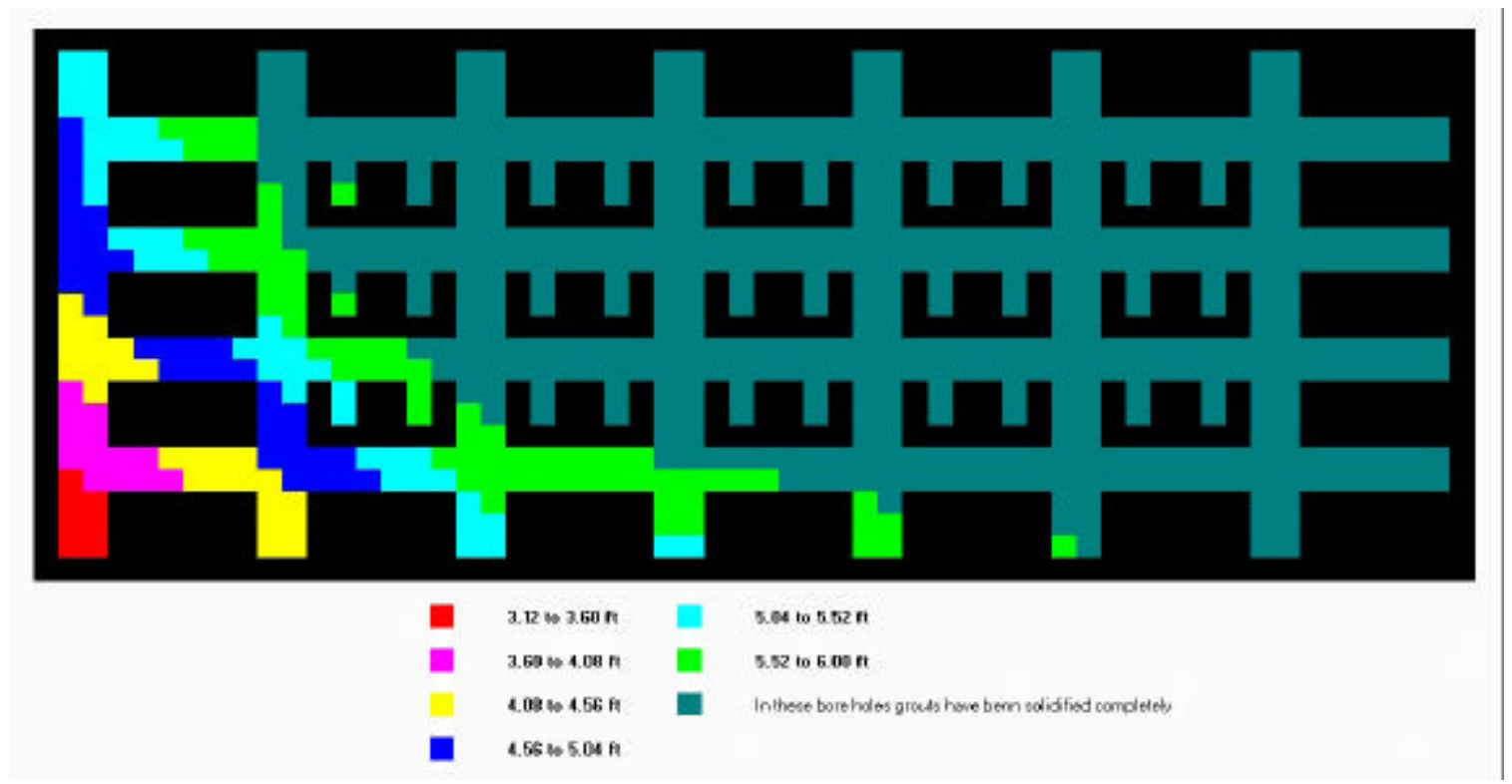

Figure 56. Flood map of grout profile after 10 days of grout injection.

Simulation was also carried out for the same for continuous grout injection at the rate of 110 tons per hour. In this case, the model converged after 5days 1 hour 18 minutes and 28 seconds of grout injection, and the result is shown in Figure 57 in the form of a flood map. Based on the simulation, the model consumed 13,343 tons of grout. According to the calculation, the model should consume 13,343 tons of grout. There is an about $0.84 \%$ volume error associated with this simulation. The maximum depth of grout was found in the dip direction and was about $6 \mathrm{ft}$. This simulation compared favorably, and the volume error is less in this case compared to other simulations, because the grid size is less in this simulation.

In the present study, the yield stress considered was $50 \mathrm{~Pa}$ and injection rate of 110 tons/hour. The simulations were also conduced for yield stress of $60 \mathrm{~Pa}$ and $70 \mathrm{~Pa}$ and the flow rate of 120 tons/hour. From the analyses, it was found that for large scale-simulation like Crown III mine grout injection, there is no significant difference of the slightly increased yield stress as well as injection rate. From the overall analyses of the Crown III room and pillar mine simulation, it was found that the Groutnet program simulated the injection schedule well, which compares favorably well with the existing conditions. 


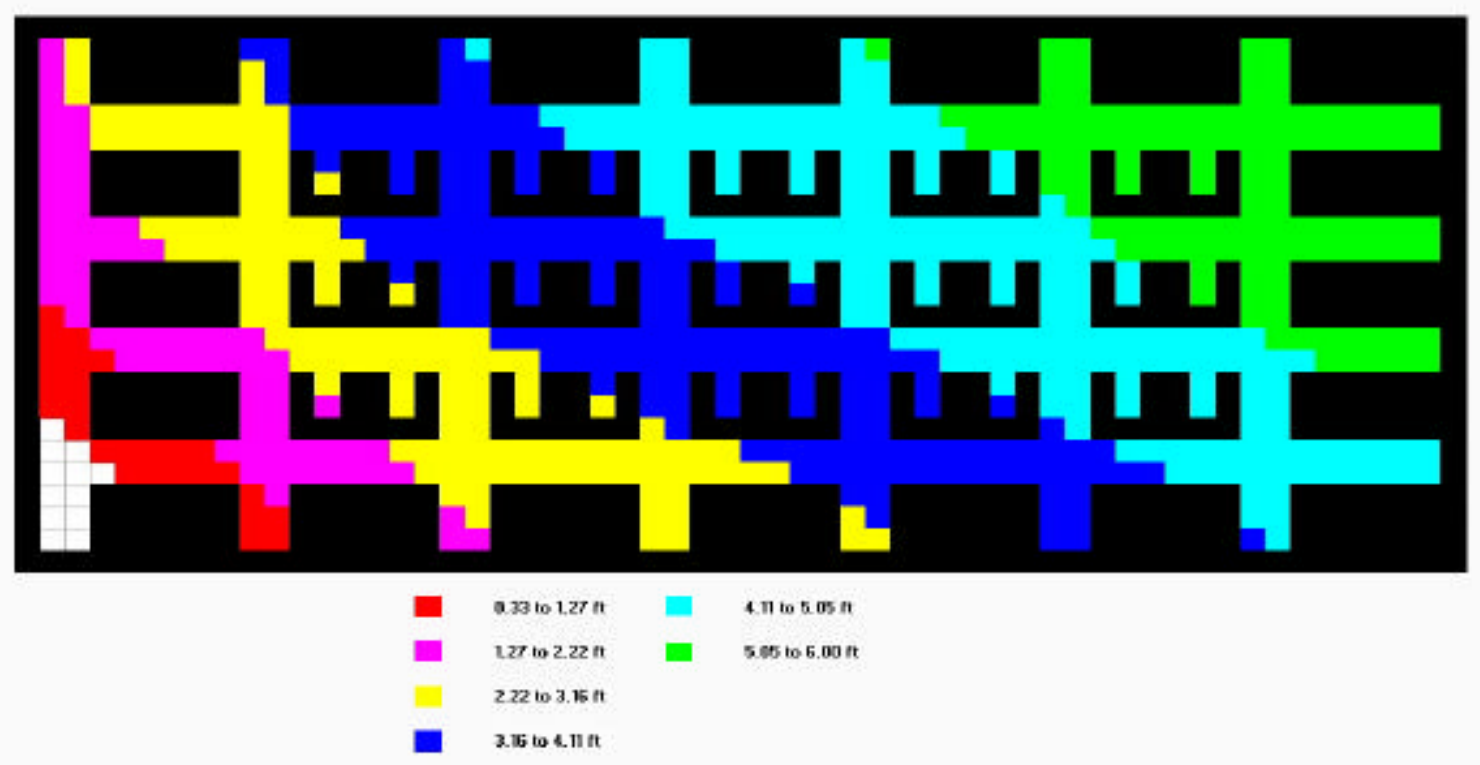

Figure 57. Flood map of continuous grout injection after 5days 1 hour 18 minutes and 28 seconds of grout injection. 


\section{CONCLUSIONS AND RECOMMENDATIONS}

\section{Conclusions:}

- Engineered mixes, consisting of coarse processing waste, and coal combustion byproducts, can be developed that are environmentally benign, and have appropriate strength and flow characteristics for backfilling underground.

- Two technologies, one using a concrete mixing plant, and the other using a high speed auger mixer, for making paste backfill mixes were successfully demonstrated for underground backfilling.

- About 16,000 tons of paste backfill were successfully managed underground without appropriate commercial equipment. Much larger amounts could have been managed if appropriate equipment was available.

- Short-life pillars can be designed with lower safety factors in room-and-pillar mine design. Such pillars permit higher extraction ratio from a mining area, and allow ample time for backfilling to be done to achieve long-term ground stability in the area.

- Backfilling should be planned for 24-hour operation so that the paste backfill does not have a chance to set up.

- Underground management of coal processing waste and CCBs have significant economic and environmental advantages over surface management. However, the management costs could be slightly higher where land acquisition costs are high such as in central Illinois.

- Groutnet appears to provide reasonable simulation of flow behavior of grout in room-and-pillar mine workings. Some modifications to the model (modeling large areas with limited computer time) would be very beneficial.

- The model predicted that a typical fly ash grout will flow at least 300-ft from the injection point.

- The model suggests that about 13,000 tons of grout may be pumped from a single borehole in a typical room-and-pillar mine before refusal.

- Pumping rate provides significant advantages in terms of the amount of grout pumped and the time to pump.

- Continuous pumping of grout without stoppages is highly recommended.

\section{Recommendations}

- The cooperating coal company has an interest in commercializing the developed technology if appropriate finances can be arranged. ICCI and OCDM/DCCA 
should assist the company to demonstrate the technologies over an extended period of time.

- Regulatory agencies, such as Illinois EPA, Illinois Office of Mines and Minerals, Office of Surface Mining, and Mine Safety and Health Administration should be contacted to develop appropriate guidelines for permitting and implementation of underground management of coal processing waste and coal combustion byproducts.

Recently completed research and development related to underground management of coal processing waste and CCBs in Illinois should be discussed with USEPA and Illinois EPA. This may influence regulations related to mine fills that are being considered by USEPA. 


\section{REFERENCES}

Atkinson, J. H., 1995, Numerical Simulation of the Flow of FBC-Ash Grout, Unpublished Masters Thesis, West Virginia University, Morgantown, WV.

Brackebusch, F. W., 1994, Basics of paste backfill systems, Mining Engineering, October, pp. 1175-1178.

Brady, B. H. G. and Brown, E. T., 1985, Rock Mechanics for Underground Mining, Allen \& Unwin, London, 527 p.

Brown, J. D. and Meyerhof, G. G., 1969, Experimental Study of Bearing Capacity in Layered Clays, Proceedings Seventh International Conference Soil Mechanics Foundation Engineering, Mexico City, Vol. 2, pp. 45 - 51.

Carlson, E. J., 1975, Hydraulic model studies for backfilling mining cavities (Second series of tests), U.S. Bureau of Mines REC-ERC-75-3, Under Modification No. 1 to Agreement No. H0230011.

Caldwell, Mike, 1999, Economic Analysis: Underground Placement of Coal Processing Waste and Coal Combustion By-Products Based Backfill for Enhanced Mining Economics, A Report Prepared by the Freeman United Coal Company

Chugh, Y. P. and W. M. Pytel (1992), Design of partial extraction coal mine layouts for week floor strata conditions, in Proceedings of the Workshop on Coal Pillar Mechanics and Design, IC 9315, Bureau of Mines, pp. 32-49.

Chugh, Y. P. and W. M. Pytel (1994), SIUPANEL.3D and SIUPANEL.3DE models for partial extraction room-and-pillar and longwall mining, Final Report submitted to Generic Mineral Technology Center, Mine Systems Design and Ground Control, Virginia Polytechnic Institute and State University, May, pp. 171.

Chugh, Y. P., D. Dutta, S. Esling, and B. Paul, 1996a, Development and demonstration of a new approach for waste coal slurry management using natural resource utilization byproducts, Phase I Annual Technical Report, Submitted to Illinois Clean Coal Institute.

Chugh, Y. P., 1996b, Management of dry flue gas desulfurization by-products in underground mines, Phase I Final Report, Submitted to Morgantown Energy Technology Center under DOE Agreement No. DE-FC21-93MC 30252.

Chugh, Y. P., D. Dutta, and S. K. Dube, 1996c, Development of coal combustion byproducts based mixtures for acid mine drainage and subsidence control, Final Report, Submitted to Maryland Department of Natural Resources, Power Plant Research Program, Contract No. RAM-1/96-004. 
Chugh, Y.P., D. Dutta, 1998, Underground placement of coal processing waste and coal combustion by-products based paste backfill for enhanced mining economics, Mid-Year Technical Report submitted to Illinois Clean Coal Institute, ICCI project number 97US-1

Galvin, J. M. and H. Wagner, 1982, Use of ash to improve strata control in board and pillar workings, in Proc. of Symposium of Strata Mechanics, New Castle Upon Tyne, April, pp. 264-270.

Gray, D. D., W. J. Head, H. J. Siriwardane, and W. A. Sack, 1995, Disposal of fluidized bed combustion ash in an underground mine to control acid mine drainage and subsidence, in Proc. of International Ash Utilization Symposium, October 23-25, Lexington, Kentucky.

Hollinderbaumer, E. W. and U. Kramer, 1994, Waste disposal and backfilling technology in the German hard coal mining industry, Bulk Solids Handling, Vol. 14, No. 4, October/December, pp. 795-798.

Maser, K. R., R. E. Wallhagen, J. Dieckman, 1975, Development of a fly ash-cement mine sealing system, U.S. Bureau of Mines, Open File Report 26-76, NTIS PB-250 611.

Meiers, J. R., D. Golden, R. Gray, and W. Yu, 1995, Fluid placement of fixated scrubber sludge to reduce surface subsidence and to abate acid mine drainage in abandoned underground coal mines, in Proc. of International Ash Utilization Symposium, October 23-25, Lexington, Kentucky.

Palarski, J., 1993, The use of fly ash, tailings, rock, and binding agents as consolidated backfill for coal mines, in Proc. of Minefill 93, ed. H. W. Gelen, the South African Inst. of Min. and Metal, pp. 403-408.

Petulanas, G. M., 1988, High volume fly ash utilization projects in the United States and Canada (2nd Ed.), Final Report CS-4446 to EPRI, Palo Alto, CA, pp. 244.

Phifer, Steven C., 1997, Underground mine strata sampling program Crown III mine \#5-Permit Condition K. Letter to Office of Mines and Minerals, March 28.

Pytel, W. M. and Chugh, Y. P., 1990, Development of a Simplified Three-Dimensional Roof-Pillar-Floor Interaction Analysis Model., Proceedings of the $8^{\text {th }}$ Annual Workshop, Generic Mineral Technology Center. Mine Systems Design and ground Control, Reno.

Pytel, W. M. and Chugh, Y. P., 1991a, Simplified three-dimensional roof-pillar-floor interaction analysis model including time effect, Proceedings of the $32^{\text {nd }} \mathrm{U}$. S. Symposium on Rock Mechanics (ed. J. C. Roegiers). A. A. Balkema/ Rotterdam,/ Brookfield, pp. 781 - 790.

Reddy, T. P., 1997, Stability, Rheology and Numerical Simulation of FBC Ash Grout for Filling Abandoned Coal Mines, Unpublished Masters Thesis, West Virginia University, Morgantown, WV. 
Stiles, J. M.and Ziemkiewicz, P. F., 1999, Solidification of AMD Treatment Sludge for Underground Mine Injection, West Virginia Surface Mine Drainage Task Force Conference, Morgantown, WV, April.

Stiles, J. M., 1999, The Numerical Simulation of the Flow of an Injected grout in Underground Room and Pillar Coal Mines, Unpublished PhD Thesis, West Virginia University, Morgantown, WV.

Vesic, A. B., 1963, Beams on elastic sub grade Winkler hypothesis, Proceedings, $6^{\text {th }}$ International Conference on soil mechanics and Foundation Engineering, Paris, Vol. 1, pp. $845-850$.

Vesic, A. S., 1973, Analysis of ultimate Loads of Shallow Foundations, Journal Soil Mech. And Found. Div., ASCE, Vol. 99, No. SM1.

Whaite, R. H. and A. S. Allen, 1975, Pumped slurry backfilling of inaccessible mine workings for subsidence control, U.S. Bureau of Mines, Information Circular 8667.

Yun-Yan Chen, DI-Wen Chen and Boshkov, S. H., 1983, Assessment of Support Performance of Consolidated Backfills in Different Mining and Geotechnical Conditions, Proceedings of the International Symposium on Mining with Backfill, Lulea, June 7 - 9, pp. $365-386$. 